
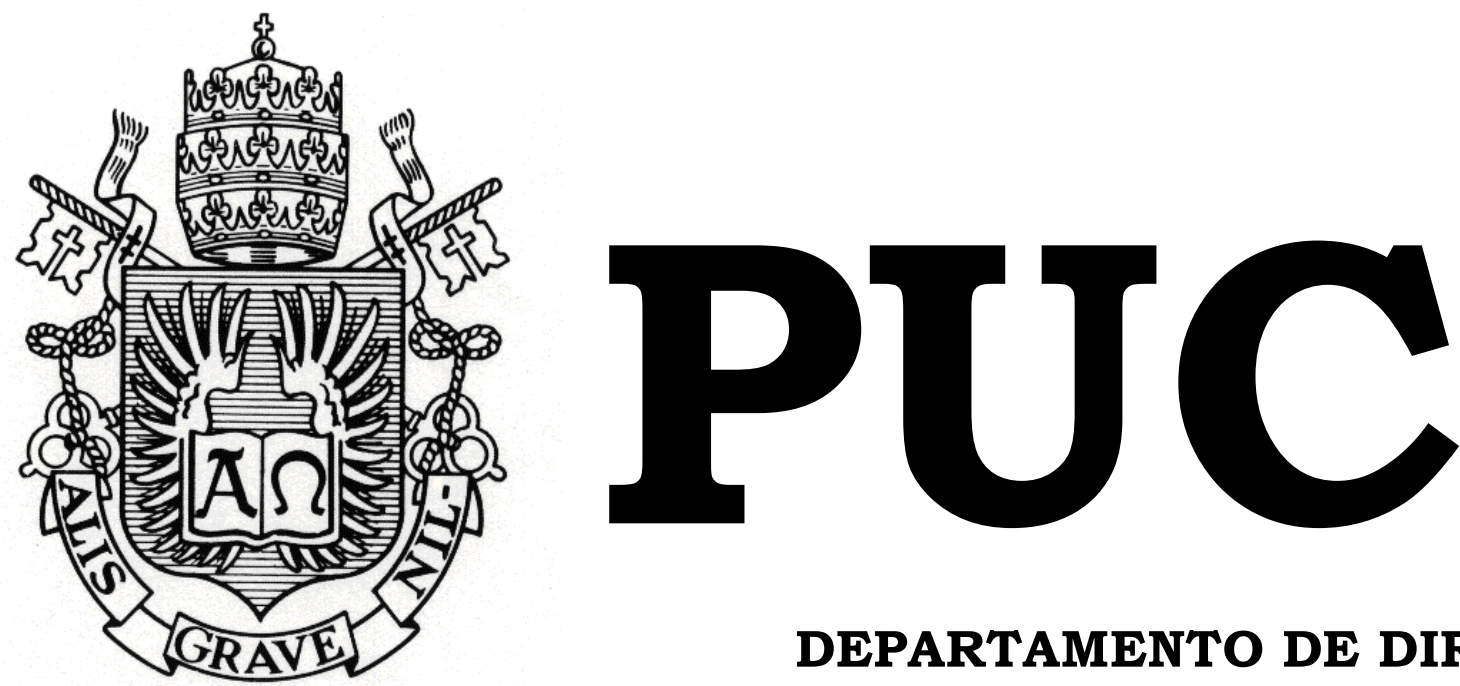

DEPARTAMENTO DE DIREITO

\title{
MEDIDAS DE DEFESA, UMA ANÁLISE HISTÓRICA, COMPARATIVA E PRÁTICA
}

Por

SABRINA FONSECA FALEIRO

ORIENTADOR(A): Francisco Antunes Maciel Müssnich

2015.2

PONTIFÍCIA UNIVERSIDADE CATÓLICA DO RIO DE JANEIRO

RUA MARQUÊS DE SÃO VICENTE, 225 - CEP 22453-900

RIO DE JANEIRO - BRASIL 


\title{
MEDIDAS DE DEFESA, UMA ANÁLISE HISTÓRICA, COMPARATIVA E PRÁTICA
}

\author{
por
}

\section{SABRINA FONSECA FALEIRO}

\author{
Monografia apresentada ao \\ Departamento de Direito da \\ Pontificia Universidade Católica do \\ Rio de Janeiro (PUC-Rio) para a \\ obtenção do Título de Bacharel em \\ Direito.
}

Orientador(a): Francisco Antunes

Maciel Müssnich 
Aos meus pais que sempre me apoiaram e se esforçaram para que eu pudesse realizar todos os meus sonhos, bem como me ensinaram que só o estudo enobrece a alma e que todo o esforço é recompensado.

Aos meus ilustríssimos mestres, em especial ao meu orientador Francisco Müssnich, que com sabedoria me guiaram pelo caminho dos estudos do Direito e despertaram em mim o amor e o apreço pelo conhecimento. 


\section{Resumo}

Este trabalho tem por objetivo desenvolver uma análise das medidas defensivas utilizadas para impedir as tomadas hostis de controle das empresas de capital aberto (hostile takeovers). Primeiramente, será estudado o poder de controle e como ele é exercido nas companhias para, em seguida, podermos abordar minuciosamente como funciona uma tomada hostil de controle e quais as medidas defensivas que podem ser utilizadas contra estes adquirentes.

Neste trabalho, analisarei, também, como as medidas defensivas estão sendo utilizadas no Brasil e se elas podem ou não ser aplicadas de acordo com nosso ordenamento jurídico. Os quatro mecanismos de proteção de empresas com dispersão acionária mais utilizados e que serão abordados neste trabalho são: as poison pills clássicas, a poison pill estatutária, o cavaleiro branco (White Knight), a joia da coroa (Crown Jewel), o pac man, o flin in e flip over e o paraquedas dourado (Golden Parachute).

Para completar o estudo, abordaremos, de forma minuciosa, os casos envolvendo empresas que fazem uso de medidas defensivas e como isso as influenciou positiva e/ou negativamente em uma futura operação de compra e venda de ações. Além disso, mostraremos os dados de uma pesquisa feita com as empresas listadas no Segmento do Novo Mercado da BM\&FBovespa e seus resultados em relação ao percentual de dispersão acionária e à utilização de mecanismos de defesa contra ofertas hostis de controle da companhia.

\section{Palavras-chave:}

Poder de controle. Aquisição Hostil. Oferta de aquisição de controle. Medidas defensivas. Poison pills. 


\section{Abstract}

This work aims to address the defensive measures used to prevent hostile takeovers of public held companies (hostile takeovers). This paper will first discuss the share control and how it is used in companies in order to analyze in detail how a hostile takeover works and what countermeasures the company can use against these purchasers.

Herein we will analyze how the defensive measures are being used in Brazil and may or may not be applied according to its legal system. We will also discuss the four most assigned measures: the classic poison pill, the statutory poison pill, White Knight, crown jewel, pac man, flin in , flip over and golden parachute.

To wrap up this work, I will scrutinize the cases involving companies that use these defensive measures and how it affected them positive and/or negative in a future share purchase and sale operation bid. In addition, I will show the data of a survey of companies listed on the "Novo Mercado" segment of BM\&FBovespa and its results regarding the percentage of share dilution and the use of defense mechanisms against takeover bids.

\section{Key Words:}

Share Control; Hostile Takeover; Takeover bid; Defensive measures; Poison pills. 


\section{Sumário}

1. Introdução e objeto de estudo .................................................... 8

2. Poder de controle e suas diversas vertentes...................................10

2.1 Tipos de Poder de Controle...................................................... 14

2.1.1 Controle Externo ................................................................... 14

2.1.2 Controle Interno................................................................. 15

2.1.2.1. Controle Quase Totalitário.................................................... 16

2.1.2.2. Controle Majoritário ........................................................... 16

2.1.2.3. Controle Minoritário ........................................................... 17

2.1.2.4. Controle Gerencial ................................................................ 18

3. Aquisições de Controle da Companhia ..........................................20

3.1 Aquisição Voluntária e Involuntária .............................................21

3.2. Aquisição Originária e Derivada ....................................................21

3.3. Aquisição mediante operação isolada ou operações conjuntas ........23

3.4 Aquisição amigável ou hostil .....................................................24

4. Medidas defensivas contra a tomada hostil de controle .......................29

4.1. Tipos de Medidas defensivas .................................................. 31

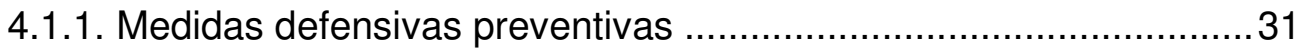

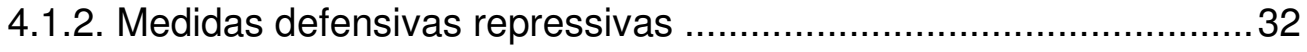

4.1.3. Medidas defensivas estatutárias ............................................... 33

4.1.4. Medidas defensivas Contratuais ................................................. 33

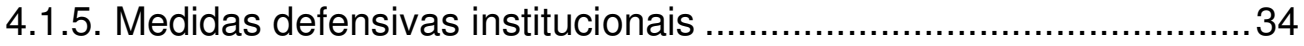

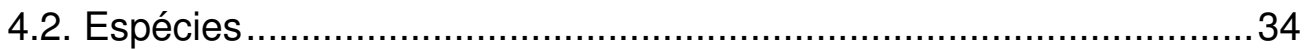

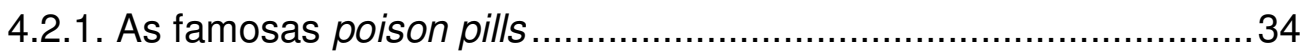

4.2.1.1. A poison pill americana ................................................... 35

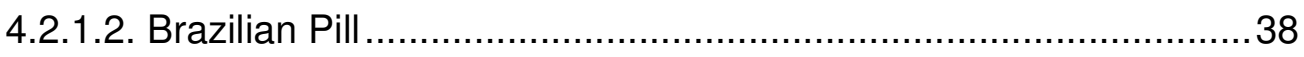

4.2.1.3. Flip In............................................................................. 41

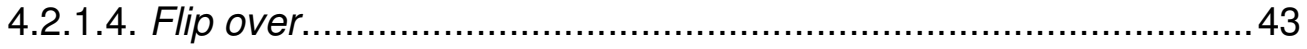

4.2.2. Cavaleiro Branco (White Knight) ....................................... 44 
4.2.3. Jóia da Coroa (Crown Jewel) ................................................. 48

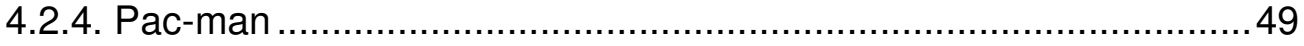

4.2.5. Paraquedas Dourado (Golden Parachute) .................................50

4.2.6. Medidas defensivas estatutárias ...............................................51

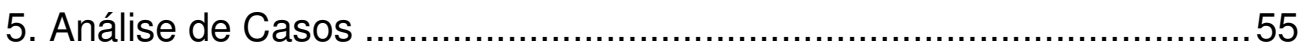

5.1. Unocal Corp. V. Mesa Petroleum Co. ...........................................55

5.2. Moran v. Household International, Inc..........................................5 57

5.3 Mittal Steel Company v. Arcelor S.A. ...........................................59

6. Análise Prática: panorama das empresas listadas no segmento do Novo Mercado da BM\&FBovespa ...............................................62

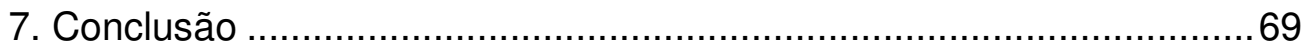

8. Referências Bibliográficas ............................................................ 72

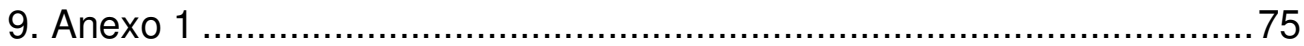




\section{Tabela de Figuras}

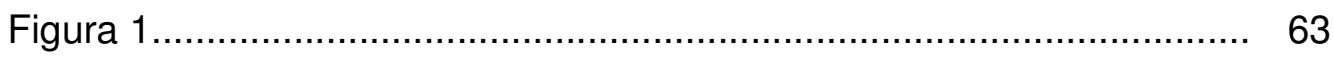

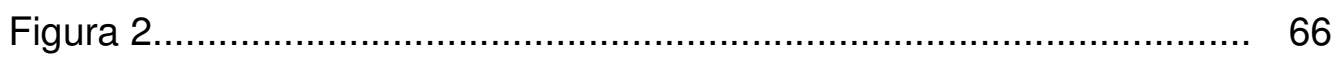

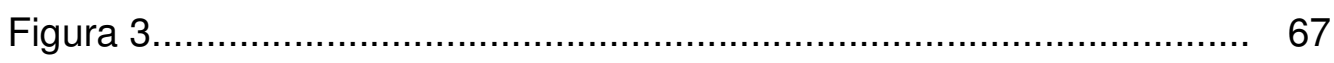

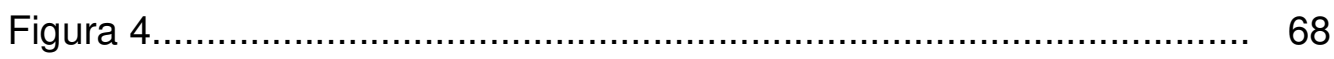




\section{Introdução e objeto de estudo}

Este estudo abordará temas que envolvem tomadas hostis de controle de uma determinada companhia e as medidas defensivas utilizadas por elas para evitar estes tipos de aquisições.

Primeiramente, revisitaremos temas como o poder de controle, que são cruciais para entender como as tomadas hostis funcionam e o que elas visam. Para fazer uma análise completa de poder de controle e elucidarmos todos os seus pontos, será explicada a tipologia do poder de controle, podendo este ser externo ou interno e suas variações como totalitário, majoritário, minoritário e gerencial.

Em seguida, serão analisadas as formas de aquisição de controle da companhia. As aquisições de controle podem ser voluntárias ou involuntárias e amigáveis ou hostis. Concluiremos que as tomadas hostis de controle ocorrem em companhias em que o controle é difuso e minoritário ou gerencial, onde se tem maior dispersão acionária.

Ato contínuo, abordaremos os tipos e espécies de medidas defensivas contra tomadas hostis de controle. Faremos um paralelo entre o direito americano e o direito brasileiro para entendermos como ocorreu seu surgimento e como estes mecanismos foram modificados ao serem importados para o Brasil. As medidas defensivas podem ser classificadas como repressivas, estatutárias, contratuais e institucionais. Além disso, essas medidas podem ser divididas nas seguintes espécies: poison pills, a primeira medida defensiva arquitetada por um advogado americano, cavaleiro branco (White Knight), pac man, paraquedas dourado (Golden Parachute) e a joia da coroa (Crown Jewel).

Ultrapassadas estas considerações, faremos uma análise prática abordando os casos mais emblemáticos tanto no direito americano quanto no brasileiro a respeito das tomadas hostis de controle da companhia e as medidas defensivas adequadas. 
Por fim, serão disponibilizados dados de uma pesquisa feita com as empresas listadas no segmento do Novo Mercado da BM\&FBovespa para avaliarmos seus resultados relativos à dispersão acionária das companhias e à utilização de medidas defensivas contra tomadas hostis de controle em seus estatutos sociais.

Para embasar este trabalho, serão utilizadas referências bibliográficas brasileiras e estrangerias, bem como reportagens, julgados, pareceres, dispositivos legais, definições de dicionários, dentre outros. 


\title{
2. Poder de controle e suas diversas vertentes
}

Para entendermos como são engendradas as aquisições de controle em uma companhia, é necessário conhecer como é exercido o poder de controle. Uma companhia de capital aberto é composta por órgãos que exercem a função de gerir e tomar decisões, bem como de orientar os rumos do negócio.

Segundo a doutrina brasileira ${ }^{1}$, a estrutura da companhia é hierarquizada: primeiro, temos a Assembleia Geral, órgão supremo capaz de tomar as decisões mais importantes e que tem o poder de eleger e destituir a qualquer momento seus administradores ${ }^{2}$.

\begin{abstract}
"No modelo legal, é, incontestavelmente, a Assembleia Geral o órgão primário, ou imediato, que investe os demais, elegendo os seus membros e podendo demitilos (LSA, art. 122, $\mathrm{n}^{\circ}$ II). Nesse sentido estritamente jurídico, nem sempre coincidente com a realidade econômica, ela é, sem dúvida, o poder supremo da companhia, como diz o Código das Obrigações suíço (art. 698), ou órgão supremo, como preferiu declarar a Lei Geral mexicana de sociedades mercantis (art. 178).
\end{abstract}

Abaixo desta, temos o Conselho de Administração, órgão obrigatório somente nas companhias abertas e de capital autorizado ${ }^{4}$, cujos membros são escolhidos por deliberação da Assembleia Geral. É válido ressaltar que, nas Companhias que possuem Conselho de Administração, a condução dos negócios se torna mais dinâmica e descentralizada da figura do acionista, sendo os administradores capazes de gerir o negócio de forma imparcial.

"O Conselho de Administração, órgão de deliberação, na verdade é intermediário entre a Assembleia Geral e a diretoria. Muitas das funções da antiga concepção de poder da assembleia geral, dado o absenteísmo dos acionistas e desinteresse pelas reuniões da assembleia, foram, pela teoria moderna, transferidos para o

\footnotetext{
${ }^{1}$ LAMY FILHO, Alfredo; BULHÕES PEDREIRA, José Luiz. Direito das Companhias. V.1, Rio de Janeiro: Forense, 2009, p. 805-806

${ }^{2}$ Art. 122, inciso II, Lei 6.404/76: “Art. 122. Compete privativamente à assembleia geral: II eleger ou destituir, a qualquer tempo, os administradores e fiscais da companhia, ressalvado o disposto no inciso II do art. 142."

${ }^{3}$ COMPARATO, Fábio Konder. In: LAMY FILHO, Alfredo; BULHÕES PEDREIRA, José Luiz. Direito das Companhias. V.1, Rio de Janeiro: Forense, 2009, p. 805.

${ }^{4}$ Art. 138, § 2º Lei 6.404/1976. Art. 138. A administração da companhia competirá, conforme dispuser o estatuto, ao conselho de administração e à diretoria, ou somente à diretoria. $\S 2^{\circ}$ As companhias abertas e as de capital autorizado terão, obrigatoriamente, conselho de administração.
} 
conselho de administração, pois ele, na teoria e na prática, efetivamente, acolhe os acionistas controladores. Daí a competência ampla do conselho de administração que, como componente do órgão de execução, estabelece a política econômica, social e financeira a ser seguida pela sociedade, e exerce permanentemente vigilância sobre os executivos lotados na diretoria. 5 ",

Ultrapassado o acima exposto, concluímos que a Assembleia Geral é o órgão supremo de uma companhia, sendo capaz de gerir e tomar decisões que influenciam todo o negócio. As deliberações na Assembleia Geral são feitas por maioria absoluta de $\operatorname{votos}^{6}$ e a pessoa jurídica ou física que tem maior número de ações ordinárias com direito a voto tem maior poder decisório e, consequentemente, detém o controle da companhia.

"A influência dominante exercida na Assembleia Geral tende a se exteriorizar para os demais órgão sociais, nos quais o poder de controle suscitará que o maior número de cargos nos órgãos da administração e fiscalização sejam ocupados por profissionais eleitos por indicação daqueles acionistas que detenham participação acionária mais relevante na companhia.",

O controle pode ser exercido por uma pessoa física ou jurídica acionista da empresa, por uma holding ou por um bloco de controle criado mediante um acordo de acionistas.

“[...] poder de controle é essa modalidade de poder exercida pelo acionista (ou grupo de acionistas), pessoa natural ou jurídica, que é titular de direitos de voto suficientes para formar a maioria nas Assembleias Gerais. É poder de fato, e não jurídico. Não é direito contido na ação: cada ação confere apenas o direito (ou poder jurídico de um voto), e o poder de controle nasce do fato da reunião na mesma pessoa (ou no mesmo grupo de pessoas) de quantidade de direitos de voto $[\ldots] .{ }^{8,}$

O conceito legal de acionista controlador e seus requisitos estão previsto no artigo 116 da Lei 6404 de 1976:

\footnotetext{
${ }^{5}$ REQUIÃO, Rubens. Curso de direito comercial. V.2, $20^{\circ}$ ed. São Paulo: Saraiva, 1995, p. 158

6 Art. 129, Lei 6.404/1976. “As deliberações da assembleia geral, ressalvadas as exceções previstas em lei, serão tomadas por maioria absoluta de votos, não se computando os votos em branco."

${ }^{7}$ NASCIMENTO, João Pedro Barroso do. Medidas defensivas à Tomada de Controle de Companhias. Editora Quartier Latin do Brasil. 2011(fl. 34)

${ }^{8}$ BULHÕES PEDREIRA, José Luiz. Alienação de Controle de Companhia Aberta. In: LAMY FILHO, Alfredo; BULHÕES PEDREIRA, José Luiz. A Lei das S.A.. v. 2, 2. ed. Rio de Janeiro: Renovar, 1996, p. 620.
} 
"Entende-se por acionista controlador a pessoa, natural ou jurídica, ou o grupo de pessoas vinculadas por acordo de voto, ou sob controle comum que: (a) é titular de direitos de sócio que lhe assegurem, de modo permanente, a maioria dos votos nas deliberações da Assembleia Geral e o poder de eleger a maioria dos administradores da companhia; e (b) usa efetivamente seu poder para dirigir as atividades sociais e orientar o funcionamento dos órgãos da companhia."

\section{O artigo $243, \S 3^{\circ}$ da mesma lei também conceitua controle:}

"Considera-se controlada a sociedade na qual a controladora, diretamente ou através de outras controladas, é titular de direitos de sócio que lhe assegurem, de modo permanente, preponderância nas deliberações sociais e o poder de eleger a maioria dos administradores."

O primeiro requisito para ser acionista controlador é ser titular de direitos de sócio. Os direitos essenciais dos acionistas estão previstos no artigo 109 e 110 c/c $111^{9}$ da Lei 6.404/1976. É válido ressaltar, neste ponto, que a lei usa a expressão "direitos de sócio" porque deseja incluir não só o acionista controlador que detém essa qualidade devido ao direito de voto conferido as suas ações, mas também ao usufrutuário das ações. A doutrina brasileira $^{10}$ explica:

"O direito de voto não pode ser transferido separadamente da propriedade da ação, mas a lei admite que o instrumento que institui usufruto possa atribuir o

\footnotetext{
${ }^{9}$ Art. 109 da Lei 6.404/76. "Art. 109 Nem o estatuto social nem a assembleia-geral poderão privar o acionista dos direitos de: I - participar dos lucros sociais; II - participar do acervo da companhia, em caso de liquidação; III - fiscalizar, na forma prevista nesta Lei, a gestão dos negócios sociais; IV - preferência para a subscrição de ações, partes beneficiárias conversíveis em ações, debêntures conversíveis em ações e bônus de subscrição, observado o disposto nos artigos 171 e 172; V retirar-se da sociedade nos casos previstos nesta Lei. $§ 1^{\circ}$ As ações de cada classe conferirão iguais direitos aos seus titulares. $\S 2^{\circ}$ Os meios, processos ou ações que a lei confere ao acionista para assegurar os seus direitos não podem ser elididos pelo estatuto ou pela assembleia-geral. § 3o O estatuto da sociedade pode estabelecer que as divergências entre os acionistas e a companhia, ou entre os acionistas controladores e os acionistas minoritários, poderão ser solucionadas mediante arbitragem, nos termos em que especificar."

Art. 110 da Lei 6.404/76. "Art. 110. A cada ação ordinária corresponde 1 (um) voto nas deliberações da assembleia-geral. $\S 1^{\circ} \mathrm{O}$ estatuto pode estabelecer limitação ao número de votos de cada acionista. $\$ 2^{\circ}$ É vedado atribuir voto plural a qualquer classe de ações."

Art. 111 da Lei 6.404/76. "Art. 111. O estatuto poderá deixar de conferir às ações preferenciais algum ou alguns dos direitos reconhecidos às ações ordinárias, inclusive o de voto, ou conferi-lo com restrições, observado o disposto no artigo $109 . \S 1^{\circ}$ As ações preferenciais sem direito de voto adquirirão o exercício desse direito se a companhia, pelo prazo previsto no estatuto, não superior a 3 (três) exercícios consecutivos, deixar de pagar os dividendos fixos ou mínimos a que fizerem jus, direito que conservarão até o pagamento, se tais dividendos não forem cumulativos, ou até que sejam pagos os cumulativos em atraso. $\S 2^{\circ} \mathrm{Na}$ mesma hipótese e sob a mesma condição do $\S 1^{\circ}$, as ações preferenciais com direito de voto restrito terão suspensas as limitações ao exercício desse direito. $\S 3^{\circ} \mathrm{O}$ estatuto poderá estipular que o disposto nos $\S \S 1^{\circ}$ e $2^{\circ}$ vigorará a partir do término da implantação do empreendimento inicial da companhia."

${ }^{10}$ LAMY FILHO, Alfredo; BULHÕES PEDREIRA, José Luiz. Direito das Companhias. V.1, Rio de Janeiro: Forense, 2009, p. 815-816
} 
direito de voto ao usufrutuário, ao nu-proprietário, ou distribuí-lo entre ambos; e como é controvertido se o usufrutuário é acionista, a lei refere-se a titular dos direitos de sócio para não deixar dúvida de que o usufrutuário que exerce o direito de voto (e o poder de controle) tem os deveres e responsabilidades de acionista controlador."

O segundo requisito é que esse poder seja exercido de forma permanente. A lei expressamente definiu que esse controle deve ser feito de forma permanente para excluir os acionistas que eventualmente detém a maioria dos votos na Assembleia Geral.

"O legislador, ao impor o requisito da permanência do poder decisório nas deliberações da assembleia geral, filiou-se às lições doutrinarias que excluem do conceito de controle o voto decisivo meramente episódico, eventual, futuro e difuso. ${ }^{11,}$

O poder de eleger a maioria dos administradores é outra importante prerrogativa legal. Além dos votos assegurarem a maioria nas deliberações na Assembleia Geral, é necessário que ele assegure o poder de eleger a maioria dos administradores, pois, devido a uma estipulação estatutária, por exemplo, o acionista pode ter a maioria dos votos para deliberar na Assembleia, mas não ter o poder de eleger a maioria dos administradores, o que descaracterizaria o poder de controle que deve ser exercido na Assembleia Geral e sobre os órgãos da administração ${ }^{12}$.

O último requisito é o uso efetivo do poder de controle. É necessário que o acionista controlador, efetivamente, exerça seus direitos de sócios para dirigir as atividades da sociedade e orientar o funcionamento dos órgãos da administração. Os artigos legais supracitados que definem poder de controle têm redações divergentes quanto à necessidade do exercício efetivo deste poder.

"O requisito de que a pessoa (ou grupo de pessoas) exerça efetivamente o poder de dirigir as atividades sociais e orientar o funcionamento dos órgãos da companhia se explica porque a definição do artigo 116 da Lei abrange pessoas naturais, e a experiência mostra que há pessoas naturais que, embora sejam titulares da maioria dos votos, não exercem efetivamente o poder de controle. [...]. Cabe destacar que a Lei não inclui esse requisito na definição de sociedade

\footnotetext{
${ }^{11}$ CARVALHOSA, Modesto. Comentários à Lei de Sociedades Anônimas. V.2, $2^{\mathrm{a}}$ ed. São Paulo: Saraiva, 1998, p. 431).

${ }^{12}$ LAMY FILHO, Alfredo; BULHÕES PEDREIRA, José Luiz. Direito das Companhias. V.1, Rio de Janeiro: Forense, 2009, p. 817
} 
controladora, constante no $\S 2^{\circ}$ do artigo 243, porque a sociedade existe para realizar seu objeto e, se este inclui a participação em companhias, ela exerce seus direitos de sócio. ${ }^{13,}$

\subsection{Tipos de Poder de Controle}

Para finalizar a abordagem sobre poder de controle, exploraremos sua tipologia. A primeira distinção a ser feita é entre controle interno e externo, desenvolvida por Fábio Konder Comparato em sua obra "O Poder de Controle na Sociedade Anônima ${ }^{14, "}$. Controle interno é aquele exercido por quem atua dentro da sociedade, é aquele executado por um agente próprio da estrutura da companhia. $\mathrm{O}$ controlador interno tem este poder mediante os votos que the são conferidos e o poder de deliberação na Assembleia Geral. Já o poder externo, é aquele exercido por um agente que não faz parte da sociedade, não integra seus órgãos internos, é um terceiro alheio a sua estrutura. Este controle pode ser exercido, por exemplo, por um terceiro que tenha crédito contra a sociedade ou algum contrato contra ela exequível.

A doutrina nacional relaciona a diferença essencial entre estes dois tipos de controle:

“[...] o controle interno (natureza associativa) redunda no exercício de uma soberania, enquanto que o controle externo (natureza contratual) outorga ao credor o exercício de um poder naturalmente contratual ou às vezes legal de constrição, o que implica tão-somente na possibilidade de responsabilização do controlador externo, por danos causados à sociedade em geral, quando e se houver agido além de seus limites contratuais. ${ }^{15,}$

\subsubsection{Controle Externo}

O controle externo é exercido por pessoa física ou jurídica estranha à sociedade e que não faça parte de nenhum órgão de sua estrutura

${ }^{13}$ Ibid.

${ }^{14}$ COMPARATO, Fábio Konder; SALOMÃOFILHO, Calixto. $O$ poder de controle na Sociedade Anônima. $4^{\mathrm{a}}$ ed. Rio de Janeiro: Forense, 2005.

${ }^{15}$ COSTA, Orcesi da. In: LAMY FILHO, Alfredo; BULHÕES PEDREIRA, José Luiz. Direito das Companhias. V.1, Rio de Janeiro: Forense, 2009, p. 831-832 
corporativa. Conforme leciona João Pedro Barroso do Nascimento $^{16}$ e Guilherme Doring Cunha Pereira ${ }^{17}$ :

"a última palavra na orientação da empresa não procede de um acionista nem dos administradores da sociedade, mas de centros decisórios estranhos à estrutura orgânica da companhia. Estes centros decisórios podem ser credores relevantes ${ }^{18}$, fornecedores de produtos e matérias-primas em situações de oligopólio ou monopólio, [...] dentre outros casos."

O controlador externo passa a ter ingerência sobre as decisões tomadas em Assembleia Geral por meio de uma sanção econômica ou jurídica como a resolução do contrato ou a imposição de multas ou indenizações. Carlo Pasteris ${ }^{19}$ explica que para caracterizar este tipo de controle são necessários os seguintes requisitos:

“a) que a influência seja de ordem econômica; b) que a influencia se estenda a toda atividade desenvolvida pela empresa controlada; c) que se trate de um estado de subordinação permanente, ou pelo menos, duradouro; e d) que haja impossibilidade para a controlada de subtrair-se a influência, sem séria ameaça de sofrer grave prejuízo econômico."

\subsubsection{Controle Interno}

Berle e Means ${ }^{20}$ dividiram o controle interno em (i) quase totalitário; (ii) majoritário; (iii) minoritário; (iv) gerencial; e (v) mediante expedientes legais. Este último foi suprido por Fábio Konder Comparato em sua obra o Poder de Controle na Sociedade Anônima ${ }^{21}$, e, por isso, não será analisado neste trabalho.

\footnotetext{
16 NASCIMENTO, João Pedro Barroso do. Medidas defensivas à Tomada de Controle de Companhias. Editora Quartier Latin do Brasil. 2011(fls 44-45)

${ }^{17}$ PEREIRA, Guilherme Doring Cunha. Alienação do Poder de Controle Acionário. São Paulo: Saraiva, 1995, p.4

18 “A Lei no 6.404 prevê, nos artigos 113 e 114, possibildiade de assegurar aos credores garantidos por penhor, usufruto ou alienaçõ fiduciária de ações, ingerência sobre o exercício do direito de voto"

${ }^{19}$ PASTERIS, Carlo. Il Controllo. Milão. Giuffrè, 1957, p. 14.

${ }^{20}$ BERLE, Adolf A; MEANS, Gardiner C. The modern corporation and private property. $9^{\mathrm{a}}$ edição. New Brunswick/New Jersey: Transaction Publishers, 2007, p. 67.

${ }^{21}$ COMPARATO, Fábio Konder; SALOMÃOFILHO, Calixto. O poder de controle na Sociedade Anônima. $4^{\mathrm{a}}$ ed. Rio de Janeiro: Forense, 2005.
} 


\subsubsection{Controle Quase Totalitário}

O acionista controlador, nesta modalidade de controle, detém algo muito próximo dos $100 \%$ das ações da companhia. Quem detém esta quantidade de ações tem o poder de aprovar quase todas as deliberações discutidas em Assembleia Geral, pois o quórum exigido pela lei é, na maior parte das deliberações, da maioria absoluta dos votos. ${ }^{22}$

Contudo, é válido ressaltar, que o próprio artigo 129 da Lei 6.404/76 estabelece, em seu parágrafo primeiro, que o estatuto pode aumentar este quórum para certas deliberações e há algumas matérias que o quórum exigido para sua aprovação é de unanimidade dos votos. São assuntos que exigem a unanimidade: 1) a alteração do projeto do estatuto (artigo 87, § $2^{\circ}$, LSA); 2) a transformação (artigo 221, LSA), salvo a exceção prevista neste artigo; 3) a cisão parcial desproporcional (artigo 229, § 5, LSA); 4) o pagamento de participação aos administradores (artigo 294, § 2º LSA); e 5) a mudança da nacionalidade (Decreto-Lei $n^{\circ} 2.627 / 40$ e artigo 1.127 do Código Civil). Nesses casos, o acionista controlador não teria o poder de aprovar essas matérias sozinho.

\subsubsection{Controle Majoritário}

Controle Majoritário é aquele tipo de controle mais clássico, ou seja, o exercido por quem detém $50 \%$ mais uma das ações com direito a voto. É o controle exercido por um acionista ou um grupo de acionistas, por meio de acordo de acionistas $^{23}$, que detêm mais da metade das ações. O artigo

\footnotetext{
22 Caput do artigo 129 da Lei 6.404/76. “Art. 129. As deliberações da assembleia-geral, ressalvadas as exceções previstas em lei, serão tomadas por maioria absoluta de votos, não se computando os votos em branco."

23 Art. 118 da Lei 6.404/76. "Art. 1188: Os acordos de acionistas, sobre a compra e venda de suas ações, preferência para adquiri-las, exercício do direito a voto, ou do poder de controle deverão ser observados pela companhia quando arquivados na sua sede.. $\S 1^{\circ}$ As obrigações ou ônus decorrentes desses acordos somente serão oponíveis a terceiros, depois de averbados nos livros de registro e nos certificados das ações, se emitidos. $\S 2^{\circ}$ Esses acordos não poderão ser invocados para eximir o acionista de responsabilidade no exercício do direito de voto (artigo 115) ou do poder de controle (artigos 116 e 117). $\$ 3^{\circ}$ Nas condições previstas no acordo, os acionistas podem promover a execução específica das obrigações assumidas. $4^{\circ}$ As ações averbadas nos termos
} 
116 da Lei 6.404/76, por exemplo, garante ao acionista que detém esta porcentagem de ações o controle sobre as deliberações da Assembleia Geral, conforme explicado no item anterior.

\subsubsection{Controle Minoritário}

Os casos de controle minoritário acontecem, normalmente, em empresas com grande dispersão acionária. Este controle é exercido por um acionista ou grupo de acionistas que detenha menos da metade das ações com direito a voto, mas possua quantidade suficiente para preencher os requisitos previstos no artigo 116 da Lei 6.404/76 e esteja inserido em uma companhia em que nenhum outro acionista detenha mais que a metade desses direitos. "A rigor, um controle minoritário bem estruturado, em companhia com grande pulverização acionária, pode atuar com a mesma eficiência que um controle majoritário. ${ }^{24,}$

Contudo, o Professor Calixto Comparato nos faz uma ressalva:

"No Brasil, a lei societária consagra o controle minoritário como princípio dentro do capital total da sociedade. A famosa regra que permitia a existência de até dois terços do capital total da empresa representados por ações preferenciais (sem voto) - art. $15, \S 2^{\circ}$, da Lei $\mathrm{n}^{\circ}$ 6.404/76, agora reduzida a no máximo $50 \%$ do total do capital - nada mais é que a consagração legal do controle. [...] Por outro lado, é preciso bastante cuidado ao se falar em controle minoritário referido ao capital total, que foi mencionado acima. Deve-se pressupor que os adquirentes das ações

deste artigo não poderão ser negociadas em bolsa ou no mercado de balcão. $§ 5^{\circ}$ No relatório anual, os órgãos da administração da companhia aberta informarão à assembleia-geral as disposições sobre política de reinvestimento de lucros e distribuição de dividendos, constantes de acordos de acionistas arquivados na companhia.§ $60 \mathrm{O}$ acordo de acionistas cujo prazo for fixado em função de termo ou condição resolutiva somente pode ser denunciado segundo suas estipulações. § 7o O mandato outorgado nos termos de acordo de acionistas para proferir, em assembleia-geral ou especial, voto contra ou a favor de determinada deliberação, poderá prever prazo superior ao constante do $\S 10$ do art. 126 desta Lei. § 8o O presidente da assembleia ou do órgão colegiado de deliberação da companhia não computará o voto proferido com infração de acordo de acionistas devidamente arquivado. §9o $\mathrm{O}$ não comparecimento à assembleia ou às reuniões dos órgãos de administração da companhia, bem como as abstenções de voto de qualquer parte de acordo de acionistas ou de membros do conselho de administração eleitos nos termos de acordo de acionistas, assegura à parte prejudicada o direito de votar com as ações pertencentes ao acionista ausente ou omisso e, no caso de membro do conselho de administração, pelo conselheiro eleito com os votos da parte prejudicada.$\S 10$. Os acionistas vinculados a acordo de acionistas deverão indicar, no ato de arquivamento, representante para comunicar-se com a companhia, para prestar ou receber informações, quando solicitadas. § 11. A companhia poderá solicitar aos membros do acordo esclarecimento sobre suas cláusulas."

${ }^{24}$ COMPARATO, Fábio Konder e FILHO, Calixto Salomão. O Poder de Controle na Sociedade Anônima. Rio de Janeiro: Editora Forense, 2008, p.65/67. 
com direito a voto têm interesse em compartilhar das decisões relativas aos destinos da companhia. Não são meros sócios capitalistas, que querem investir seus recursos sob administração de outrem. ${ }^{25}$,

\subsubsection{Controle Gerencial}

Este controle não é exercido pelo acionista em si, mas por aquelas pessoas que possuem cargos diretivos. É a forma pela qual a administração vai controlar, de alguma maneira, a companhia ou algum sistema. Essa forma de controle decorre da ausência de um controlador efetivo que passa esse controle para os administradores.

Este controle é muito comum nos Estados Unidos, onde as companhias tem grande dispersão acionária e o controle fica na mão do "board of directors ${ }^{26 ",}$, este seria para eles o "management control".

No Brasil, há uma grande discussão se existiria ou não este tipo de controle nas nossas companhias, uma vez que nossa cultura não é de pulverização do capital social nas empresas. Nelson Eizirik ${ }^{27}$ afirmava, enfaticamente, que "não existe no Brasil, nenhum caso de empresa que possa ser classificada como controlada pela direção". Mais recentemente, Ricardo Ferreira de Macedo ${ }^{28}$ se opôs a este entendimento alegando que "a situação de controle gerencial pode ser efeito não apenas de ambiente de pulverização acionária, mas, também, de outros cenários fáticos em que se veja a vacuidade de influencia dos sócios sobre a administração."

Nas companhias em que ocorre o controle gerencial, os administradores podem se perpetuar no poder por meio de procurações que

\footnotetext{
${ }^{25}$ Ibidem, p. 68.

${ }^{26}$ A tradução de board of directors para o português é Assembleia Geral e não diretoria, como seu nome pode, erroneamente, aludir. O Black's Law Dictionary define board of directors como: "The governing body elected by the shareholders to establish corporate policy, appoint executive officers, and make major business and financial decisions. (GARNER, Bryan A. Black's Law Dictionary. 4th Pocket ed. West Group, 2001, verbete board of directors, p. 81)

${ }^{27}$ EIZIRIK, Nelson. O mito do "controle gerencial”- alguns dados empíricos. RDM. São Paulo: Malheiros, nº 66, p. 103 - 106, abr./jun., 1987, p.106

${ }^{28}$ MACEDO, Ricardo Ferreira de. Controle não societário. Rio de Janeiro: Renovar, 2004, p. 135.
} 
lhe são outorgadas pelos acionistas. Segue entendimento da nossa doutrina sobre o assunto:

"Exemplo clássico da dissociação entre propriedade e controle, o chamado poder gerencial acentua, de maneira particularmente ilustrativa, instituição de uma possível dominação burocrática em que a crença na legitimidade, de forma mais intensa, depende da estrutura formal da sociedade anônima e dos mecanismos legais capazes de assegurar o domínio. Dentre esses últimos, avultam os pedidos de procurações (proxy solicitations), formulados pelos administradores para se manterem no poder, e admitidos por nossa lei de 1976 (art. 126, § 2 ${ }^{\circ}$ ). Mas é imperioso reconhecer que o management control somente se estabiliza (e propicia a dominação) quando tem o suporte das proxies, ou seja, quando não lhe falta o apoio dos acionistas. ${ }^{29,}$

Para entender como são feitas as tomadas hostis de controle é de extrema importância compreender o controle gerencial e o controle minoritário, pois estas aquisições são feitas em um mercado acionário disperso, onde não se tenha um controle totalitário ou majoritário, mas sim minoritário ou gerencial.

${ }^{29}$ GUERREIRO, José Alexandre Tavares. Sociedade anônima: poder e dominação. Revista de Direito Mercantil, Industrial, Econômico e Financeiro. São Paulo, no 53, janeiro-março/ 1984, p. 78 


\section{Aquisições de Controle da Companhia}

No Brasil, ainda temos poucas empresas com dispersão acionária, diferentemente do que acontece em países como os Estados Unidos e a Inglaterra, onde a estrutura de controle disperso é predominante ${ }^{30}$.

"No sistema norte-americano, a separação entre propriedade e controle decorre da diluição do capital e de o poder de comando empresarial ser exercido pelos administradores. No Brasil, pelo contrário, o sistema é de um controle fortemente concentrado, de modo que o conflito central a ser regulado é o que se estabelece entre controlador e não-controladores. ${ }^{31,}$

Silvia Valadares realizou uma pesquisa na qual demonstrou que no mercado de ações brasileiro, em 2000, das 325 companhias abertas, 203 $(62,5 \%)$ tinham um único acionista detendo mais de $50 \%$ das ações com poder de voto. Além disso, nas outras 122 empresas, em que não se tinha um controle majoritário, os acionistas detinham em média $29 \%$ das ações com direito a voto, i.e., mesmo não tendo a maioria, tinham uma parte considerável. $^{32}$

Dessa forma, fica claro que no Brasil é mais difícil termos tomadas hostis de controle de uma determinada companhia, pois o controle é extremamente concentrado, permitindo uma espécie de "bloqueio" a estes tipos de aquisição.

"No sistema de controle diluído, o poder de controle é passível de disputa no mercado acionário, enquanto que, no sistema de controle concentrado, ele permanece bloqueado com o controlador, de forma que somente pode ser negociado diretamente com este. ${ }^{33,}$

Contudo, não existe apenas a aquisição hostil de controle, ela pode ser também amigável, voluntária ou involuntária, originária ou derivada e

${ }^{30}$ CASTRO, Rodrigo R. Monteiro; ARAGÃO, Leandro Santos de. Direito Societário: Desafios Atuais. São Paulo: Quartier Latin, p. 124, 2009)

${ }^{31}$ MUNHOZ, Eduardo Secchi. Desafios do direito societário brasileiro na disciplina da companhia aberta: avaliação dos sistemas de controle diluído e concentrado.

32 VALADARES, Silvia Mourthé; LEAL, Ricardo Pereira Câmara. Ownership and Control Structure of Brazilian Companies. 2000. Disponível em SSR: $<$ http://papers.ssrn.com/sol3/papers.cfm?abstract_id=213409>. Acessado em 24/09/2015.

33 CASTRO, Rodrigo R. Monteiro; ARAGÃO, Leandro Santos de. Direito Societário: Desafios Atuais. São Paulo: Quartier Latin, p. 124, 2009. 
decorrente de uma operação isolada ou de operações conjuntas, conforme será analisado, a seguir.

\title{
3.1 Aquisição Voluntária e Involuntária
}

A aquisição de controle voluntária é aquela que tem o elemento volitivo, ou seja, o adquirente deseja tomar o controle daquela companhia. Já na tomada involuntária de controle, o adquirente não deseja esta aquisição, ele a faz por fatores externos e alheios a sua vontade.

\begin{abstract}
"As aquisições involuntárias compreendem várias hipóteses, com destaque para a mais flagrante delas, que é a decorrente de sucessão causa mortis, em que o adquirente do poder de controle assume o status socci de controlador por conta de efeitos sucessórios. [...] Por sua vez, a aquisição voluntária de controle pode ocorrer, dentre outras hipóteses, na compra e venda de ações mediante contrato celebrado entre vendedor e comprador; na oferta pública de aquisição de ações; e nas operações de reorganização societária, em que o adquirente volitivamente coordena atos que lhe assegurarão a obtenção do poder de controle sobre a companhia. ${ }^{34,}$
\end{abstract}

\subsection{Aquisição Originária e Derivada}

Em uma aquisição originária de controle, não há controle sendo transmitido, pois está sendo formado um bloco de controle que antes não existia. Ninguém perdeu ou alienou o controle para outra pessoa, mas aquela que adquiriu as ações se tornou controladora; um bloco de controle originário será formado a partir da consolidação de determinada operação.

A aquisição originária pode ocorrer, por exemplo, por meio da criação de uma holding ou acordo de acionistas. Bem como, uma pessoa que já detinha uma certa quantidade de ações pode comprar as ações de outro acionista e, a partir desse negócio jurídico, deter o controle da companhia que anteriormente era disperso.

Já a aquisição derivada, decorre de um negócio jurídico de quem já detinha o controle. A pessoa que possuía o poder de controle a priore aliena

\footnotetext{
34 NASCIMENTO, João Pedro Barroso do. Medidas defensivas à Tomada de Controle de Companhias. Editora Quartier Latin do Brasil. 2011, pp. 57-58.
} 
para um terceiro este bloco, passando, então, a ser o acionista controlador

daquela companhia. A doutrina brasileira leciona neste sentido:

"A aquisição do poder de controle pressupõe sua transferência por pessoa que o detenha, e, como o controle é poder de fato fundado no bloco de controle, sua transferência entre pessoas pressupõe a transmissão da propriedade do conjunto de ações, que é a fonte desse poder. Para que possa ocorrer a transferência do poder de controle é indispensável, portanto, (a) a existência do bloco de controle, como universalidade, no patrimônio de uma pessoa (ou grupo de pessoas), e (b) fato jurídico cujo efeito seja a transmissão da propriedade desse conjunto de ações. ${ }^{35, "}$

Esta diferenciação é extremamente importante para entender o artigo 254-A da Lei $6.404 / 76^{36}$, porque este artigo fala em alienação de controle, pressupondo a existência de um bloco de controle anterior para que este possa ser transmitido. Este artigo trata das aquisições derivadas de controle da companhia e a obrigatoriedade de realização de oferta publica de aquisição de ações nesses casos.

"É importante examinar se houve a transferência do controle, de modo a determinar se há incidência da obrigatoriedade de realização de oferta pública de compra das ações pertencentes aos acionistas minoritários, de acordo com o artigo 254-A da Lei 6.404/76. ${ }^{37,}$

\footnotetext{
${ }^{35}$ LAMY FILHO, Alfredo; BULHÕES PEDREIRA, José Luiz. Direito das Companhias. V.1, Rio de Janeiro: Forense, 2009, p. 829

${ }^{36}$ Art. 254-A. A alienação, direta ou indireta, do controle de companhia aberta somente poderá ser contratada sob a condição, suspensiva ou resolutiva, de que o adquirente se obrigue a fazer oferta pública de aquisição das ações com direito a voto de propriedade dos demais acionistas da companhia, de modo a lhes assegurar o preço no mínimo igual a $80 \%$ (oitenta por cento) do valor pago por ação com direito a voto, integrante do bloco de controle. § 1o Entende-se como alienação de controle a transferência, de forma direta ou indireta, de ações integrantes do bloco de controle, de ações vinculadas a acordos de acionistas e de valores mobiliários conversíveis em ações com direito a voto, cessão de direitos de subscrição de ações e de outros títulos ou direitos relativos a valores mobiliários conversíveis em ações que venham a resultar na alienação de controle acionário da sociedade.§ 2o A Comissão de Valores Mobiliários autorizará a alienação de controle de que trata o caput, desde que verificado que as condições da oferta pública atendem aos requisitos legais. § 3o Compete à Comissão de Valores Mobiliários estabelecer normas a serem observadas na oferta pública de que trata o caput. $\S 40 \mathrm{O}$ adquirente do controle acionário de companhia aberta poderá oferecer aos acionistas minoritários a opção de permanecer na companhia, mediante o pagamento de um prêmio equivalente à diferença entre o valor de mercado das ações e o valor pago por ação integrante do bloco de controle.

37 NASCIMENTO, João Pedro Barroso do. Medidas defensivas à Tomada de Controle de Companhias. Editora Quartier Latin do Brasil. 2011, p. 60
} 


\title{
3.3. Aquisição mediante operação isolada ou operações conjuntas
}

O controle pode ser adquirido por meio de uma única operação ou por várias operações sucessivas que, ao final, garantem o poder de controle para $o$ adquirente.

Normalmente, a aquisição de controle por uma operação isolada é feita mediante um contrato de compra e venda de ações que garante ao adquirente o bloco de controle da companhia-alvo.

A aquisição através de operações conjuntas é conhecida como "escalada acionária". Este tipo de operação acontece quando o adquirente por meio de várias operações de compra de pequenas quantidades de ações na bolsa de valores adquire, em um certo momento, um percentual que the garante o controle da companhia-alvo.

Contudo, a escalada acionária sofre algumas restrições que visam impedir a aquisição de controle discricionária e sem consentimento dos acionistas e/ou administradores da companhia.

\begin{abstract}
"A aquisição de controle da companhia-alvo, por meio de uma série de operações coordenadas, é realizada quando o adquirente interessado visa a surpreender os acionistas e os administradores da companhia-alvo e, quiçá, o próprio mercado em geral, em relação ao objetivo de tomar o controle da companhia-alvo. Entretanto, esse método suscita inconvenientes que tendem a inviabilizar a tomada de controle. Sempre há a possibilidade de que as operações individuais para a aquisição de pequenas quantidades de ações de emissão da companhia-alvo sofram interferências externas de terceiros igualmente interessados na compra das ações de emissão da companhia-alvo. ${ }^{38, "}$
\end{abstract}

A instrução da CVM n n $^{\circ}$ 358/02 discorre sobre a divulgação de informações em casos de negociação de valores mobiliários e de aquisição de lote significativo de ações de emissão de uma determinada companhia. $\mathrm{O}$ artigo 12 estipula que sempre que a participação direta ou indireta de uma pessoa aumentar em 5\% esta deve divulgar a operação. Além dessa obrigação, o $\S 6$ do artigo $4^{\circ}$ da Lei 6.404/76 estabelece que se acionista controlador adquirir ações que aumentem seu poder de controle dentro da companhia, este é obrigado a fazer uma Oferta Pública por Aumento de

${ }^{38}$ NASCIMENTO, João Pedro Barroso do. Medidas defensivas à Tomada de Controle de Companhias. Editora Quartier Latin do Brasil. 2011, p. 64 
Participação nos moldes do artigo ora mencionado e do artigo $2^{\circ}$ da Instrução da CVM no 361/02.

“A obrigatoriedade de realização de oferta pública por aumento de participação tem por objetivo evitar o chamado "fechamento branco de capital", verificado quando, em decorrência de aquisições feitas pelo acionista controlador (ou por quem está vinculado a ele, sob alguma forma), reduz-se o nível de liquidez das ações em circulação no mercado, deixando o investidor em situação desfavorável. ${ }^{39,}$

É evidente que o legislador buscou impor barreiras para as escaladas acionárias, impedindo que tomadas de controle sejam feitas à revelia dos direitos e garantias dos acionistas minoritários.

\subsection{Aquisição amigável ou hostil}

A aquisição amigável de controle de uma companhia alvo é aquela na qual os dealers negociam os termos em que a operação irá se concretizar e estabelecem, normalmente, um contrato formal de compra e venda de ações, obtendo, assim, o consentimento dos acionistas e administradores para concluir a aquisição.

Contudo, em alguns casos, os acionistas ou administradores da empresa são contra estas operações e os futuros adquirentes, mesmo assim, decidem continuar com a oferta. Há casos em que o potencial adquirente nem sequer negocia com os acionistas ou administradores da companhia alvo, ele apenas faz uma oferta pública de aquisição de ações. Nesses casos, temos as chamadas ofertas ou aquisições ou tomadas hostis de controle da companhia.

Segue entendimento doutrinário sobre oferta pública de aquisição de ações:

"é uma modalidade de aquisição de poder de controle voluntária, uma que pressupõe obrigatoriamente a manifestação de vontade do ofertante; originária, já que o bloco de ações representativas do controle se formará inicial e originalmente a partir da reunião, pelo ofertante, das ações que antes se encontravam dispersas no mercado acionário; e decorrente de operação isolada, isto é, a oferta pública é tendente a adquirir poder de controle em uma única

39 NASCIMENTO, João Pedro Barroso do. Medidas defensivas à Tomada de Controle de Companhias. Editora Quartier Latin do Brasil. 2011, p. 66 
operação. As ofertas públicas podem ser amigáveis ou hostis, conforme sejam efetuadas com ou sem consentimento dos administradores e/ou determinados acionistas e/ou grupos de acionistas relevantes da companhia-alvo., ${ }^{40}$

As tomadas hostis de controle ou hostile takeovers surgiram com força na década de 1980 nos Estados Unidos, onde sua prática é muito comum devido à alta dispersão acionária. Há estudos que mostram que durante esta época, conhecida como "deal decade", aproximadamente metade das companhias americanas mais influentes receberam propostas hostis de aquisição de controle. ${ }^{41}$

Os estados Unidos passaram por basicamente duas fases de tomada hostil de controle da companhia. A primeira foi caracterizada pelas brigas por procurações para representações nas Assembleias Gerais (proxy fights). Em seguida, veio a chamada "Saturday Night Live", quando as ofertas eram feitas sexta a noite e os acionistas tinham até o início da próxima semana para decidir se a aceitavam ou não. O pagamento seria feito em dinheiro e, à medida que os acionistas da companhia alvo aceitassem a oferta, eles eram pagos (first come first serve). Contudo, a quantidade de ações adquiridas eram aquelas suficientes para garantir o controle ao adquirente. Após assumir o controle, eles "espremiam" para fora (squeezed out) da companhia os acionistas que não ofertaram suas ações por meio de uma nova oferta publica de aquisição de ações, evidentemente, por um valor muito mais baixo, ou por meio de uma incorporação da companhia alvo por uma companhia que o adquirente já detinha. Esta operação ficou conhecida como "two-tier-takeover". Esse tipo de aquisição de controle foi muito usado nos Estados Unidos até o advento do Williams Act, em 1968, que criou barreiras para essas tomadas hostis e também mecanismos de proteção para as companhias alvo. ${ }^{42}$

Contudo, alguns doutrinadores alegam que, após revisões, o Williams Act acabou se tornando mais um mecanismo de obrigação de

\footnotetext{
40 NASCIMENTO, João Pedro Barroso do. Medidas defensivas à Tomada de Controle de Companhias. Editora Quartier Latin do Brasil. 2011, p. 75

${ }^{41}$ MITCHELL, Mark L.; MULHERIN, J. Harold. The impact of Industry shocks on Takeover and Restructuring Activity. Journal of Financial Economist. V.41, 1996, pp. 193-229.

${ }^{42}$ LIPTON, Martin. Takeovers \& Freezeouts. Law Journal Press
} 
informação do que propriamente uma proteção contra tomadas hostis de controle. $^{43}$

A revista World Finance listou, em 2014, as 5 maiores tomadas hostis de controle de todos os tempos. Segundo eles, a grande aquisição do milênio foi a da AOL pela Time Warner por 164 bilhões de dólares em 2000. Estão na lista, também, as aquisições da companhia de biotecnologia Genzyme e da Bolsa de Valores de Nova Iorque. ${ }^{44}$

Segundo a doutrina nacional:

"a oferta pública de aquisição de controle é o mecanismo clássico aplicado nas tomadas de controle hostis de companhias abertas. Quando há resistência à aquisição de controle por parte dos administradores e/ou determinados acionistas relevantes, em cenário de dispersão acionária, tal instrumento revela-se eficiente, pois permite a realização da operação diretamente com os acionistas detentores de ações dispersas no mercado, independentemente de aprovação dos órgãos sociais. ${ }^{45,}$

Em 2008, o mercado presenciou uma oferta pública de ações envolvendo players brasileiros. A Inbev fez uma oferta pública de aquisição das ações da Anheuser-Busch, oferecendo 65 dólares por ação da companhia alvo (um prêmio de $18 \%$ em relação ao recorde histórico da cotação da ação) $)^{46}$. Apesar da $\mathrm{AB}$ ter feito uma contra oferta dizendo que se os cariocas Jorge Paulo Lemann, Marcel Telles e Beto Sucupira quisessem adquirir o controle de uma das maiores fabricantes de cerveja do mundo, eles tinham que desembolsar mais dinheiro e fazer uma oferta melhor em 24 horas, é evidente que foi uma oferta hostil de controle feita por parte da Inbev. A Inbev ofereceu 5 dólares a mais por ação e após seis meses de negociação e convencimento dos acionistas e administradores de ambas as empresas, eles adquiriram o controle da maior cervejaria americana.

\footnotetext{
43 "As first proposed, the Williams Act would have largely curtailed tender offer through substantive restrictions. Congress had become alarmed that large corporations were being rapidly taken over by unknown "raiders" and wished to slow down this movement. However, the SEC succeeded in redrafting the proposed bill, turning it largely into a disclosure statute. (CHOPER, Jesse H.; COFFEE Jr. John C.; e GILSON, Ronald J. Cases and materials on corporations. $7^{\mathrm{a}}$ ed. Nova York : Aspen Publishers, 2008.

${ }_{44}$ www.worldfinance.com/strategy/the-top-five-hostile-takeovers-of-all-time Acessado em 24/09/2015.

${ }^{45}$ NASCIMENTO, João Pedro Barroso do. Medidas defensivas à Tomada de Controle de Companhias. Editora Quartier Latin do Brasil. 2011, p. 99.

${ }^{46}$ CORREA, Cristiane. Sonho Grande. GMT Editores Ltda. 2013 Pags 19-37.
} 
Já no Brasil, as empresas começaram apenas em 1940 a dispersar seu capital, o que fez com que as ofertas e tomadas hostis de controle não fossem muito comuns no mercado nacional. Este aumento na dispersão acionária se deu, principalmente, pela criação do Novo Mercado pela BM\&FBovespa, lançado no ano de $2000^{47}$. Mais adiante, faremos uma análise minuciosa das empresas que compõem o Novo Mercado e seus estatutos em relação à proteção contra ofertas hostis de aquisição de controle e como seu quadro de acionistas é estruturado ${ }^{48}$. Além da criação do Novo Mercado, a conjuntura econômica também propiciou este novo rumo das companhias por meio da redução da inflação, estabilidade macroeconômica e a abertura comercial. ${ }^{49}$

Um caso emblemático de companhia com dispersão acionária no Brasil é o da Lojas Renner que em 2000 pulverizou seu controle tendo colocado quase $100 \%$ das suas ações para negociação na Bolsa de Valores no segmento do Novo Mercado. Em 2011, o free float da empresa era de $99,65 \%$ de suas ações com direito a voto.

Contudo, pondera Alfredo Lamy Filho e José Luiz Bulhões Pedreira:

"No Brasil tem sido raros os casos de aquisição de controle mediante oferta pública porque são raras as comapnhias abertas cujo controle é assegurado pela posse de ações representativas de menos de $50 \%$ do capital com direito a voto. As transferências de controle de companhia aberta se realizam em geral mediante contratos de cessão de controle.

Também nos mercados de valores mobiliários mais desenvolvidos, a prática das ofertas públicas para aquisição de controle experimenta um declínio, dentre

\footnotetext{
47 "Lançado no ano 2000, o Novo Mercado estabeleceu desde sua criação um padrão de governança corporativa altamente diferenciado. A partir da primeira listagem, em 2002, ele se tornou o padrão de transparência e governança exigido pelos investidores para as novas aberturas de capital. Na última década, o Novo Mercado firmou-se como uma seção destinada à negociação de ações de empresas que adotam, voluntariamente, práticas de governança corporativa adicionais às que são exigidas pela legislação brasileira. A listagem nesse segmento especial implica na adoção de um conjunto de regras societárias que ampliam os direitos dos acionistas, além da adoção de uma política de divulgação de informações mais transparente e abrangente. Texto extraído do site da MN\&FBovesba. Disponível em: <http://www.bmfbovespa.com.br/ptbr/servicos/solucoes-para-empresas/segmentos-de-listagem/novo-mercado.aspx?idioma=pt-br $>$. Acessado em 20/09/2015

${ }^{48}$ A BM\&FBovspa estipula para as empresas que façam parte do segmento do Novo Mercado que estas tenham $25 \%$ das suas ações em circulação (free float). Disponível em: <http://www.bmfbovespa.com.br/pt-br/servicos/solucoes-para-empresas/segmentos-delistagem/novo-mercado.aspx?idioma=pt-br $>$. Acessado em 28/09/2015

49 Migalhas. A nova S.A. e o controle minoritário. Disponível em: $<$ http://www.migalhas.com.br/dePeso/16,MI184525,101048-

A+nova+SA+e+o+controle+minoritario $>$. Acessado em: 28/09/2015
} 
outras razões porque o processo não enseja uma prévia auditoria destinada a verificar a situação patrimonial da companhia visada ("due diligence"), inclusive no que se refere a insuficiências ativas e contingências ocultas. ${ }^{50,}$

Neste cenário, analisaremos quais são os mecanismos que as companhias alvo de tomadas hostis de controle podem usar em seus estatutos para garantir que o controle se mantenha estático. Além disso, observaremos quais são as consequências positivas e negativas destas barreiras. É inegável que a maior parte das companhias abertas brasileiras não possuem grande dispersão acionária, como acontece nos Estados Unidos. No caso da Anheuser-Busch, por exemplo, no momento da oferta publica de aquisição pela Inbev, a família Busch detinha apenas $4 \%$ das ações desta empresa. Contudo no Brasil, a maior parte das empresas listadas no novo mercado apresentam em seus estatutos sociais medidas defensivas contra ofertas hostis de controle, conforme será analisado adiante.

${ }^{50}$ LAMY FILHO, Alfredo; BULHÕES PEDREIRA, José Luiz. Direito das Companhias. V.1, Rio de Janeiro: Forense, 2009, p. 2033 


\section{Medidas defensivas contra a tomada hostil de controle}

As pílulas de veneno (poison pills ${ }^{51}$ ), ou afasta-tubarões (shark repellents $^{52}$ ) ou dispositivo porco-espinho (porcupine provisions ${ }^{53}$ ) são nomes dados às medidas defensivas (takeover defenses ${ }^{54}$ ) contra tomada hostil de controle da companhia (hostile takeovers ${ }^{55}$ ).

Francisco Mussnich afirma que o emprego do termo "poison pills" é utilizado erroneamente para caracterizar as medidas adotadas por companhias brasileiras para impedir a tomada de controle hostil. ${ }^{56}$ As poison pills, como foram concebidas na doutrina americana, são mecanismos que, uma vez utilizados, excluem dos acionistas proteções ou direitos típicos que lhes são inerentes, i.e., lhes é proibido exercer a preferência na subscrição ou aquisição de ações. O preço de emissão é fixado num valor menor do que aquele estipulado pelo mercado. Já as cláusulas estatutárias utilizadas no Brasil, normalmente, estipulam um percentual mínimo de ações que o acionista, ao atingi-lo, fica obrigado a fazer uma oferta pública para aquisição das demais ações de emissão da

\footnotetext{
51 O Black's Law Dictionary define poison pill como: “A corporation's defense against an unwanted takeover bid whereby shareholders are granted the right to acquire equity or debt securities at a favorable price to increase the bidder's acquisition cost. (GARNER, Bryan A. Black's Law Dictionary. $4^{\text {th }}$ Pocket ed. West Group, 2001, verbete poison pill, p. 576)

52 Black's Law Dictionary define shark repellent como: "1. Takeover defense. 2. More specifically, a charter or bylaw provision designated to impede hostile bids to acquire a controlling interest in a corporation". (GARNER, Bryan A. Op. cit., verbete shark repellent, p. 690)

${ }^{53}$ Black's Law Dictionary define porcupine provisions como: "A clause in a corporation's charter or bylaws designed to prevent a takeover without the consent of the board of directors." (GARNER, Bryan A. Op. cit., verbete porcupine provision, p. 578)

${ }^{54}$ Black's Law Dictionary define takeover defense como: "A measure taken by a corporation to discourage hostile takeover attempts." (GARNER, Bryan A. Op. cit., verbete takeover defense, p. 740)

55 Black's Law Dictionary define takeover e hostile takeover, respectivamente, como: "The acquisition of ownership or control of a corporation. A takeover is typically accomplished by a purchase of shares or assets, a tender offer, or a merger." e "A takeover that is resisted by the target corporation." (GARNER, Bryan A. Op. cit., verbete takeover e hostile takeover, p. 739-740)

56 MUSSNICH, Francisco Antunes Maciel; PERES, Fabio Henrique. Administração deve colaborar para o melhor uso das poison pills. Disponível em: $<$ http://www.bmalaw.com.br/nova_internet/arquivos/Artigos/Numero\%2025.pdf $>$. Acessado em $25 / 09 / 2015$.
} 
companhia, tornando extremamente onerosa essa aquisição e impedindo que ele adquira o controle da companhia alvo. ${ }^{57}$

Modesto Carvalhosa explica como essas cláusulas de proteção acionária, visando impedir tomadas hostis de controle, são aplicadas nos estatutos das companhias:

"A posion pill estatutária mais utilizada pelas companhias abertas brasileiras consiste em cláusula estabelecendo que a aquisição de determinado percentual de ações de emissão da companhia $(15 \%, 20 \%, 25 \%$..) gera, para o adquirente, o dever de realizar Oferta Pública de Aquisição de ações (OPA) dirigida a todos os demais acionistas" $" 58$.

Vale ressaltar que, para Francisco Mussnich, as "pílulas de veneno" utilizadas no Brasil deveriam ser chamadas de "Brazilian Pills", uma vez que em nada se assemelham às poison pills americanas.

"Poison pill nada mais é do que a nomenclatura dada para um tipo de medida defensiva criada nos Estados Unidos59, mas que em nada se assemelha com a variação tupiniquim incorporada em alguns estatutos sociais de companhias brasileiras60, uma evidente confusão de espécie com gênero. ${ }^{61,62}$

Com base nessas ponderações, iremos analisar os tipos de medidas defensivas contra tomada hostil de controle da companhia: (i) preventivas; (ii) posteriores; (iii) estatutárias; (iv) contratuais e (v) institucionais, para, em seguida, analisarmos as espécies mais utilizadas: (i) poison pills; (ii) cavaleiro branco; (iii) jóia da coroa; (iv) pac man; (v) paraquedas dourado; e (iv) medidas defensivas estatutárias

57 NASCIMENTO, João Pedro Barroso do. Medidas defensivas à Tomada de Controle de Companhias. Editora Quartier Latin do Brasil. 2011, p. 48-49

${ }^{58}$ CARVALHOSA, Modesto. As poison pills Estatutárias na Prática Brasileira: alguns aspectos de sua legalidade. In: CASTRO, Rodrigo R. Monteiro; ARAGÃO, Leandro Santos de. Direito societário: Desafios Atuais. São Paulo: Quartier Latin, 2009, p.25.

${ }^{59}$ LIPTON, Martin; ROWE, Paul K. Pills POlls and Professors. A Reply to Professor Gilson. New York University Center for Law and Business Research Paper, n. 01-006, abr. 2001, p. 15.

NASCIMENTO, João Pedro Barroso do. Medidas defensivas à Tomada de Controle de Companhias. Editora Quartier Latin do Brasil. 2011, p. 48, 49 e 149.

60 NASCIMENTO, João Pedro Barroso do. Medidas defensivas à Tomada de Controle de Companhias. Editora Quartier Latin do Brasil. 2011, p. 48, 49 e 149.

${ }^{61}$ GAMEZ, Milton. Ora, Pílulas, Revista IstoÉ Dinheiro, n. 614. 15/07/2009, p. 89. Francisco Mussnich alega: "Os advogados confundiram uma espécie com o gênero".

${ }^{62}$ MUSSNICH, Francisco Antunes Maciel. Análise prática e considerações sobre a realidade e a aplicação das medidas de proteção à tomada hostil de controle nos estatutos sociais das companhias abertas brasileiras (Brazilian pills). In: SILVA, Alexandre Coutro. Direito Societário, Estudos sobre a lei de sociedades por ações. Editora Saraiva, 2013. P. 253 - 278 
Neste trabalho, não vamos confundir a espécie poison pill com o gênero medidas defensivas. Por isso, exploraremos em separado e, conforme acima exposto, do jeito correto que ela deve ser empregada. Seguiremos na mesma linha que João Pedro Barroso do Nascimento abordou em seu trabalho sobre o tema:

\begin{abstract}
"As pílulas de veneno, referidas como poison pills, são provavelmente a forma mais famosa de defesa contra tomadas de controle hostis. Em alguns casos, esta espécie de medida defensiva é erroneamente classificada como se fosse gênero em que se inserem todas as demais espécies de medidas de defesa. Ocorre que a poison pill é apenas mais uma das espécies do gênero das medidas defensivas. ${ }^{63}$ ", (grifo nosso).
\end{abstract}

\title{
4.1. Tipos de Medidas defensivas
}

As medidas defensivas podem ser identificadas quanto ao momento em que são empregadas, bem como em relação a sua natureza jurídica. Se estas medidas são implementadas antes de uma oferta hostil de aquisição de controle, elas são chamadas de preventivas, se são adotadas após o potencial adquirente fazer a oferta, elas são chamadas de posteriores ou repressivas. Em relação a sua natureza jurídica, estas medidas podem ser classificadas como estatutárias, contratuais ou institucionais.

\subsubsection{Medidas defensivas preventivas}

As medidas defensivas preventivas são aquelas adotadas antes de se ter uma oferta hostil de aquisição de controle e servem, justamente, para impedir este tipo de operação.

Uma vez adotadas, elas criam uma espécie de "barreira" que impede que o controle da companhia seja "tomado" por um terceiro alheio aos órgãos que a compõem. Normalmente, as empresas com grande dispersão acionária fazem uso desse mecanismo para impedir os hostile takeovers. ${ }^{63}$ NASCIMENTO, João Pedro Barroso do. Medidas defensivas à Tomada de Controle de
Companhias. Editora Quartier Latin do Brasil. 2011, p.135 
Tais medidas também são utilizadas como estratégia para garantir tempo suficiente aos órgãos da administração da companhia ou seus acionistas para tomarem medidas com o intuito de impedir que o controle da companhia alvo seja adquirido hostilmente.

As principais espécies de medidas preventivas são as pílulas de veneno e o paraquedas dourado, conforme serão estudadas mais adiante.

\subsubsection{Medidas defensivas repressivas}

As medidas defensivas repressivas são aquelas adotadas posteriormente a uma oferta de aquisição hostil da companhia. Neste caso, a companhia alvo já sofreu uma oferta para aquisição de controle e adota algum mecanismo para impedir sua concretização.

O limite que se estabeleceu para que as medidas defensivas sejam ad hoc é a data da divulgação da OPA nos termos do artigo $4^{\circ}$-A da Instrução da CVM 361 de $2002 .^{64}$

“[...] enquanto o anúncio da oferta pública ou qualquer outro comunicado oficial ao mercado não houver sido realizado e, consequentemente, a tentativa de tomada de controle por meio de oferta pública não tenha se tornado de conhecimento público, a medida defensiva que vier a ser utilizada poderá ser enquadrada como preventiva. ${ }^{65 "}$

\footnotetext{
${ }^{64}$ Instrução da CVM 361/02. Art. $4^{\circ}$-A: Art. 4o-A O ofertante deve guardar sigilo a respeito da OPA até sua divulgação ao mercado, bem como zelar para que seus administradores, empregados, assessores e terceiros de sua confiança também o façam. 1 1o A obrigação de sigilo prevista no caput se estende até: I - a data em que for divulgado fato relevante referente a OPA sujeita a registro na CVM, nos termos do art. 9o da Instrução CVM no 358, de 3 de janeiro de 2002; ou II - a data em que for publicado o edital de OPA não sujeita a registro na CVM. § 2o Caso a informação escape do controle do ofertante antes da data referida no $§ 10$, o potencial ofertante deverá, imediatamente: I - publicar o instrumento de OPA, nos termos do art. 11; ou II - informar ao mercado que tem interesse em realizar a OPA, ou que está considerando essa possibilidade, embora ainda não tenha certeza de sua efetivação. § 3o Exceto quando se tratar de OPA sujeita a registro, o anúncio previsto no §2o, inciso II, deverá: I - incluir as informações indicadas nos itens "i" até "m" do inciso I do Anexo II; e II - ser encaminhado ao diretor de relações com investidores da companhia objeto, para que este o divulgue imediatamente ao mercado, por meio de sistema eletrônico disponível na página da CVM na rede mundial de computadores. § 4o Caso o ofertante divulgue o anúncio previsto no $\$ 2 \mathrm{o}$, inciso II, a CVM poderá fixar um prazo para que ele: I - publique o instrumento de OPA, nos termos do art. 11; ou II - anuncie ao mercado, de maneira inequívoca, que não pretende realizar a OPA dentro do período de 6 (seis) meses.

${ }_{65}$ NASCIMENTO, João Pedro Barroso do. Medidas defensivas à Tomada de Controle de Companhias. Editora Quartier Latin do Brasil. 2011, p.120
} 
Estas defesas muitas vezes são usadas pelas companhias alvo depois que uma medida defensiva preventiva já foi empregada. Elas são mecanismos que reforçam a proteção contra tomadas hostis de controle. As medidas mais comuns deste tipo e que serão estudados adiante são: pac man, jóia da coroa (Crown Jewel) e cavaleiro branco (White Knight).

\subsubsection{Medidas defensivas estatutárias}

As medidas defensivas estatutárias são aquelas que estão descritas nos estatutos sociais das empresas e visam, de antemão, garantir uma proteção à oferta hostil de aquisição de controle que suas companhias possam vir a sofrer.

Este tema será amplamente debatido nos itens 4.2.6 e 6, quando analisaremos, respectivamente, esta espécie e os estatutos sociais das empresas listadas no segmento do Novo Mercado da Bolsa de Valores e suas cláusulas que estabelecem medidas defensivas estatutárias.

\subsubsection{Medidas defensivas Contratuais}

São medidas empregadas com o intuito de proteger a companhia alvo por meio de contratos contendo disposições que funcionam como uma barreira contra os raiders que desejam tomar o controle da companhia.

Um tipo clássico de medida defensiva contratual é o da joia da coroa ou Crown Jewel defense, como ficou conhecida nos Estados Unidos. Esse mecanismo visa tirar o interesse dos raiders da companhia alvo. Geralmente, a pessoa jurídica ou física que faz a oferta hostil de aquisição de controle tem interesse em algum ativo valioso da companhia, então, por meio de um contrato de compra e venda, de hipoteca, de garantia, de empréstimo, dentre outros, a companhia tira o interesse daquele potencial adquirente da sua "joia da coroa". A companhia alvo se torna menos atraente para o investidor devido a essas barreiras. 


\subsubsection{Medidas defensivas institucionais}

Neste tipo de medida, a companhia alvo cria organismos, como por exemplo uma holding, fundos de investimentos, trusts, consórcios de sociedade, dentre outros, para fortalecer a companhia e protegê-la contra terceiros que visam tomar seu controle.

A doutrina caracteriza a medida defensiva institucional como:

"aquelas técnicas de organização de controle interno que consistem na criação de um organismo, personalizado ou não, com o objetivo de consolidar a titularidade do poder soberano da sociedade e disciplinar-lhe o exercício. ${ }^{66, "}$

Este tipo de mecanismo só pode ser empregado posteriormente a uma oferta hostil de aquisição de controle, uma vez que sua função é criar um bloco de controle e concentrar as ações da companhia alvo e, caso existisse a priori, esta oferta nem seria feita. Vale relembrar que as ofertas hostis de controle são executadas em empresas que tem grande dispersão acionária.

\subsection{Espécies}

Uma vez compreendidos os tipos de medidas defensivas, examinaremos suas espécies mais usadas e conhecidas. Vale ressaltar que são muitas as espécies de medidas defensivas que foram criadas e desenvolvidas ao longo dos anos em diferentes países, mas nem todas serão estudadas neste trabalho.

\subsubsection{As famosas poison pills}

Neste trabalho se faz necessário um breve histórico do surgimento das pílulas de veneno nos Estados Unidos e no Brasil para compreendermos suas principais diferenças e o cenário em que elas estão inseridas.

66 COMPARATO, Fábio Konder; SALOMÃO FILHO, Calixto. O poder de Controle na Sociedade Anônima. $4^{\mathrm{a}}$ ed. Rio de Janeiro: Forense, 2005, p. 145) 
É evidente que o mercado de ações americano é formado por empresas com uma dispersão acionária muito mais expressiva. Já o mercado de ações brasileiro, ainda é muito incipiente e traz uma tradição de empresas com controle acionário muito concentrado, principalmente, na mão de famílias que fundaram as companhias. Por isso, existem diferenças inerentes entre as duas e, como já foi abordado, as poison pills brasileiras em nada se assemelham à americana, apenas levam esse nome erroneamente.

\title{
4.2.1.1. A poison pill americana
}

Nos Estados Unidos as poison pills foram criadas pelo advogado nova iorquino Martin Lipton na década de $80^{67}$. Elas foram concebidas para impedir as tomadas hostis de controle das companhias que estavam ocorrendo, frequentemente, nos Estados Unidos nas décadas de 60 e 70, conforme acima já mencionado.

Nas palavras do próprio advogado Martin Lipton, em um artigo escrito em 2002, ele disserta:

\begin{abstract}
"September of this year will mark the twentieth anniversary of the publication of my memorandum recommending that companies adopt the poison pill, which I invented in the summer of 1982 to deal with the takeover abuses that emerged in the 1970s and had become endemic by the end of the decade. The pill prevents a hostile tender offer from being consummated unless and until the board of directors of the target redeems the pill. ${ }^{68,}$
\end{abstract}

Nos Estados Unidos antes de 1960, as discussões acadêmicas e judicias com foco em regras que poderiam ser aplicadas contra ofertas de tomada de controle de uma determinada companhia eram muito escassas. A partir de 1970, este assunto se tornou extremamente relevante, uma vez que

${ }^{67}$ VELASCO, Julian. Justo do it: an antidote to the Poison Pill. Emory Law Journal, n. 52, jul. 2003, p. 849-908

${ }^{68}$ LIPTON, Martin. Pills, polls and professors Redux. The University of Chicago Law Review. Volume 69. Summer 2002. Number 3. P. 1039. Segue tradução livre do trecho: "Em setembro deste ano farão 20 anos da publicação do meu memorandum recomendando as companhias a adotarem pílulas de venenos as quais inventei no verão de 1982 para lidar com os abusos nas tomadas de poder que surgiram no ano de 1970 e se tornaram endêmicas no final desta década. As pílulas previnem ofertas hostis de serem consumadas ao menos e até que o conselho de administração da companhia alvo retire a pílula." 
as tomadas hostis se tornaram mais frequentes. Contudo, não se tinha jurisprudência ou leis que regulassem os mecanismos para impedir essa aquisição de controle, acarretando grande preocupação entre os advogados das companhias-alvo.

"In this period, the role of the board of directors and the grounds on which it was to act in responding to a hostile takeover bid were nebulous and had yet to be definitely determined. ${ }^{69}$,

Como uma forma de trazer esclarecimentos para este assunto, Martin Lipton, em 1979, escreveu a dissertação “Takeover Bid in the Target's Boardroom". Neste artigo, ele aconselhava os administradores das companhias a governar de acordo com a "business judgement rule ${ }^{70}{ }_{-}^{71}$ ", e, ao exercer seu julgamento, eles deveriam levar em consideração o interesse dos empregados, da comunidade, bem como os interesses de longo prazo dos acionistas. Contudo, sua posição não foi bem aceita pelos doutrinadores da época, que rejeitavam a ideia de um conselho de administração ativo e contra as tomadas hostis de controle. Eles acreditavam na "Rule of Passivity", segundo a qual os administradores deveriam ficar passivos e

\footnotetext{
${ }^{69}$ LIPTON, Martin. Pills, polls and professors Redux. The University of Chicago Law Review. Volume 69. Summer 2002. Number 3. P. 1037. Segue tradução livre do trecho: "Neste período, o papel do conselho de administração e os mecanismos de ação em resposta a uma oferta hostil de tomada de controle era nebuloso e ainda tinha que ser delimitado."

${ }^{70}$ O Black's Law Dictionary define business judgment rule como: "The presumption that in making decisions not involving direct self-interest or self-dealing, corporate directors act on an informed basis, in good faith, and in the honest belief that their actions are in the corporation's best interest. The rule shields directors and officers from liability for unprofitable transactions. If the transactions were made in good faith, with due care, and within the director's or officers' authority." (GARNER, Bryan A. Black's Law Dictionary. $4^{\text {th }}$ Pocket ed. West Group, 2001, verbete business judgment rule, p. 92)

${ }^{71}$ Luiz Antonio Soares explica a Business Judgment Rule no direito brasileiro: "O $\$ 6^{\circ}$ do artigo 159 da Lei ${ }^{\circ}$ 6.404/1976 autoriza o juiz a reconhecer que o administrador agiu de boa-fé e visando o interesse da companhia, na ação social de responsabilidade civil por prejuízo patrimonial causado à sociedade. Nesse caso, poderá ser excluída a responsabilidade do administrador. Tratase de possibilidade advinda do direito americano e denominada business judgment rule. Com a aplicação da regra da decisão empresarial, protege-se a discricionariedade das decisões tomadas pelos administradores de empresas quando do exercício da função, limitando o poder de interferência do juiz em face da presunção de regularidade dos atos de administração. A abordagem leva em conta o condicionamento da equidade às hipóteses legais (art. 127 do Código de Processo Civil) e o princípio da livre apreciação da prova pelo juiz (art. 133), além de disposições da lei societária que afastam a responsabilidade do administrador por ato regular de gestão (art. 158 da LSA) e o dever de diligência (art. 153), e conclui pela natureza própria da disposição analisada ( $\S 6^{\circ}$ do art. 159 da LSA) e sua incidência ou não nas sociedades contratuais.". HENTZ, Luiz Antonio Soares. Business Judgement Rule no direito Brasileiro. Disponível em: <http://www.bv.fapesp.br/pt/auxilios/82901/business-judgment-rule-no-direitosocietario-brasileiro/>. Acessado em: 27/09/2015.
} 
apenas aconselhar os acionistas. As pessoas a favor das tomadas hostis de controle encontraram suporte entre os grupos de economistas que acreditavam na teoria eficiente do mercado (efficient market theory) que servia como base para o argumento de que os bens dos acionistas poderiam ser maximizados, tornando ilegal as formas de proteção contra tomadas de controle. Segundo eles, a vontade de um ofertante de pagar um prêmio pela aquisição do controle demonstra sua habilidade de gerir melhor e mais eficientemente os bens da companhia alvo. ${ }^{72}$

Martin Lipton se posiciona veementemente contra este posicionamento. Segundo o advogado nova iorquino, o argumento supracitado servia apenas para garantir os ganhos a curto prazo dos acionistas e as companhias teriam dificuldade de atuar em um ambiente em que elas estariam, frequentemente, "for sale". Ele afirma também que nem sempre o preço das ações refletem seu valor intrínseco, uma vez que as ineficiências do mercado podem existir a qualquer tempo. Além disso, várias ofertas de tomada de controle eram oportunidades para conseguir um valor baixo dos bens daquela companhia e não necessariamente uma coisa boa para economia. ${ }^{73}$

Em setembro de 1982, Martin Lipton publicou um memorando descrevendo o "Warrant Dividend Plan" que seria uma espécie de garantia que os administradores da companhia alvo poderiam decretar para ganhar mais tempo para reagir a uma oferta hostil de controle e fazer com que os administradores mantivessem o controle no processo de responder à oferta. $^{74}$

Carlos Martins Neto em sua dissertação explica este processo: "O Warrant Dividend Plan tinha como instrumento a distribuição de "direitos"

\footnotetext{
${ }^{72}$ LIPTON, Martin. Pills, polls and professors Redux. The University of Chicago Law Review. Volume 69. Summer 2002. Number 3. pp. 1040-1041.

${ }^{73}$ Ibid. pp. 1042-1043.

${ }^{74}$ Lipton afirma: "In September 1982, I published a memorandum describing the "Warrant Dividend Plan". The "warrant" was a security that could be issued by the board of directors of a target company (before or after it was faced with an unsolicited bid) that would have the effect of increasing the time available to the board to react to an unsolicited bid and allowing the board to maintain control over the process of responding to the bid.". LIPTON, Martin. Pills, polls and professors Redux. The University of Chicago Law Review. Volume 69. Summer 2002. Number 3. P. 1044.
} 
(que tinham feição de uma opção de compra cujo exercício era condicionado à verificação e determinados eventos) a todos os acionistas da companhia, à proporção de um “direito" por ação. O funcionamento da estratégia era relativamente simples: quando um acionista (ou grupo de acionistas) realizasse uma oferta para adquirir o controle ou lograsse adquirir, via mercado, um percentual específico do capital social da companhia (geralmente $15 \%$ a $20 \%$ ), ou anunciasse sua intenção de o fazer, a faculdade de se adquirir ações a preços muito abaixo dos praticados no mercado, conferida pelos "direitos", poderia, então, ser exercida. Assim, ocorrendo o evento que caracterizava o "gatilho" da poison pill, cada "direito" outorgaria a seu titular a faculdade de adquirir uma ou mais ações da companhia alvo (no caso das poison pills do tipo flip in) ou uma ou mais ações do potencial adquirente do controle (no caso das poison pills do tipo flip over), em ambos os casos, por um preço substancialmente abaixo do valor de mercado. Como os "direitos" expressamente não podiam ser exercidos pelo potencial adquirente do controle, este acabava tendo sua participação bastante diluída na companhia alvo, de forma que o prosseguimento da operação de aquisição do controle, tanto via mercado, quanto via oferta pública, tornava-se extremamente caro. ${ }^{75,} 76$

Este mecanismo começou a ser usado por muitas companhias e, seis meses depois, quando um banqueiro foi perguntado sobre como poderíamos chamar este plano, ele respondeu: "poison pill".

\subsubsection{Brazilian Pill}

No Brasil, as poison pills foram importadas do direito americano em uma época em que as empresas estavam dispersando mais suas ações e vivenciando uma nova fase no mercado acionário nacional.

\footnotetext{
75 SUBRAMANIAN, Guhan. The Poison Pill. Harvard Business School Review, Cambridge, 9 Nov. 2001, p. 1.

${ }^{76}$ NETO, Carlos Martins. Dispersão acionária, tomada hostil de controle e poison pills: breve reflexões. Disponível em: <http://www.bocater.com.br/artigos/dispersao-acionaria-tomada-hostilcontrole-poison-pills/>. Acessado em 29/09/2015.
} 
Até a década de 60, as empresas Brasileiras eram caracterizadas pela grande concentração das ações na mão de um grupo pequeno. As empresas, na maioria das vezes, eram compostas por famílias que detinham o controle daquela companhia e se perpetuavam no poder por gerações.

Na década de 70, ocorreu a promulgação das Leis 6.305 e 6.404 que trouxeram grandes avanços e inovações para a regularização do direito societário brasileiro. Além das reformas que foram essenciais para garantir a adequação desta lei no cenário econômico-politico que o país passava, é válido ressaltar, para este trabalho, a modificação trazida pela Lei 9.457/97 que revogou o artigo 254 da Lei 6.404 que consistia na instituição do "tag along", propiciando uma maior facilidade na alienação dos blocos de controle retirando a necessidade de aprovação da CVM para se concretizar.

Já em 2001, a Lei 10.303 trouxe maior proteção ao acionista minoritário como, por exemplo, a inclusão do artigo $254-\mathrm{A}^{77}$ que estabeleceu a obrigatoriedade de oferta publica de ações em caso de alienação de controle. Neste ponto, é válido ressaltar que alguns autores,

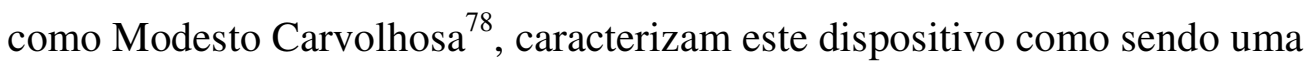
poison pill legal. Contudo, eu não vislumbro este artigo como uma poison pill clássica, pois este instituto, como foi originariamente formulado, visa impedir uma aquisição de controle hostil da companhia e, para se ter uma

\footnotetext{
${ }^{77}$ Art. 254-A. A alienação, direta ou indireta, do controle de companhia aberta somente poderá ser contratada sob a condição, suspensiva ou resolutiva, de que o adquirente se obrigue a fazer oferta pública de aquisição das ações com direito a voto de propriedade dos demais acionistas da companhia, de modo a lhes assegurar o preço no mínimo igual a $80 \%$ (oitenta por cento) do valor pago por ação com direito a voto, integrante do bloco de controle. $\S 1$ 1o Entende-se como alienação de controle a transferência, de forma direta ou indireta, de ações integrantes do bloco de controle, de ações vinculadas a acordos de acionistas e de valores mobiliários conversíveis em ações com direito a voto, cessão de direitos de subscrição de ações e de outros títulos ou direitos relativos a valores mobiliários conversíveis em ações que venham a resultar na alienação de controle acionário da sociedade. . § 2o A Comissão de Valores Mobiliários autorizará a alienação de controle de que trata o caput, desde que verificado que as condições da oferta pública atendem aos requisitos legais. § 3o Compete à Comissão de Valores Mobiliários estabelecer normas a serem observadas na oferta pública de que trata o caput. (Incluído pela Lei $n^{\circ} 10.303$, de 2001). § 4o $\mathrm{O}$ adquirente do controle acionário de companhia aberta poderá oferecer aos acionistas minoritários a opção de permanecer na companhia, mediante o pagamento de um prêmio equivalente à diferença entre o valor de mercado das ações e o valor pago por ação integrante do bloco de controle.
}

${ }^{78}$ CARVAlHOSA, Modesto. In: CASTRO, Rodrigo R. Monteiro; ARAGÃO, Leandro de Santos. Direito Societário: Desafios atuais. Sao Paulo: Quartier Latin, 2009, p. 23-24. 
aquisição hostil, é necessário que o capital da companhia alvo seja disperso e diluído. Dessa forma, o artigo 254-A, ao tratar de alienação de controle, aborda apenas companhias que já tenham a priore um controle definido e concentração acionária.

Além disso, a Bolsa de Valores de São Paulo, nesta época, criou o segmento do Novo Mercado visando garantir uma maior confiança das companhias em pulverizar seu capital. Segue texto elaborado por Maria Helena Santana, "a premissa básica que norteou a criação, em dezembro de 2000, do Novo Mercado, segmento especial de listagem da Bolsa de Valores de São Paulo (BOVESPA) destinado a empresas que se comprometem com a adoção de padrões elevados de governança corporativa, foi de que a redução da percepção de risco por parte dos investidores influenciaria positivamente a valorização e a liquidez das ações.[...] Ao final de junho de 2006, 31 companhias encontravam-se listadas no Novo Mercado, 13 no Nível 2, e 34 no Nível 1, representando $52,99 \%$ da capitalização de mercado e $53,88 \%$ do volume negociado. ${ }^{79,}$. Algumas empresas que pulverizaram seu capital nos anos 2000 foram a Lojas Renner S.A, a Perdigão S.A., a Diagnósticos da América S.A., a Submarino e a Empresa Brasileira de Aeronáutica.

Nesta conjuntura, as empresas brasileiras buscaram mecanismos para impedir que seu controle ficasse vulnerável, uma vez que suas ações começavam a se dispersar na bolsa de valores. Dessa forma, as companhias "importaram" do direito americano as pílulas de veneno e as implementarem em seus estatutos sociais.

Vale ressaltar que nós não incorporamos as poison pills na maneira em que foram idealizadas nos Estado Unidos, uma vez que nosso ordenamento impede esta prática. Nós adaptamos os estatutos das companhias para que eles contivessem medidas que impedissem as tomadas hostis de aquisição de controle.

\footnotetext{
${ }^{79}$ SANTANA, Maria Helena. O novo Mercado por Maria Helena. The International Bank for Reconstruction and Development/The World Bank Group. Disponível em: $<$ http://www.bmfbovespa.com.br/Pdf/focus5.pdf $>$. Acessado em 28/09/2015.
} 
As poison pills como foram originalmente arquitetadas não podem ser inseridas em nosso sistema jurídico porque (i) a administração é vedada de recomprar as ações de sua própria companhia a partir do momento que se tenha uma oferta hostil de aquisição de controle, pois feriria o artigo $2^{\circ}$ da Instrução da CVM n ${ }^{\circ} 10 / 80^{80}$; (ii) não poderiam ser conferidos tratamentos desiguais para os acionistas de uma mesma companhia, nos moldes do $\S 1^{\circ}$ do art. 109 da Lei $6.404 / 76^{81}$; (iii) não se pode conceder aos acionistas a possibilidade de aquisição de ações por um preço inferior ao do mercado, pois este deve observar as regras estabelecidas no artigo 170 da Lei 6.404/76 e o parecer de orientação CVM n ${ }^{\circ}$ 01/78.

A seguir, analisaremos as medidas defensivas contra tomadas hostis de controle usadas no Brasil e nos Estados Unidos e concluiremos se estas estão em conformidade com as normas legais nacionais. Visitaremos também as "clausulas pétreas" que algumas companhias estipularam em seus estatutos e o motivo que fez com que a CVM as proibisse.

\subsubsection{Flip In}

A poison pill do tipo flip in é amplamente utilizada nos Estados Unidos e, em conjunto com a flip over, elas são subespécies da pílula de veneno.

A Investopedia define flip in como:

"a type of poison pill strategy in which existing shareholders, but not acquiring shareholders, are allowed to purchase shares in the target company at a discount. A flip-in poison pill takeover defense dilutes the value of the shares purchased by the acquiring company by flooding the market with new shares, while also

\footnotetext{
${ }^{80}$ Artigo $2^{\circ}$ da Instrução da CVM n ${ }^{\circ}$ 10/80. "Art. 2o A aquisição, de modo direto ou indireto, de ações de emissão da companhia, para permanência em tesouraria ou cancelamento, é vedada quando: a) importar diminuição do capital social; b) requerer a utilização de recursos superiores ao saldo de lucros ou reservas disponíveis, constantes do último balanço; c) criar por ação ou omissão, direta ou indiretamente, condições artificiais de demanda, oferta ou preço das ações ou envolver práticas não equitativas; d) tiver por objeto ações não integralizadas ou pertencentes ao acionista controlador; e) estiver em curso oferta pública de aquisição de suas ações."

$81 \S 1^{\circ}$ do art. 109 da Lei 6.404/76. "Art. 109. $\S 1^{\circ}$ As ações de cada classe conferirão iguais direitos aos seus titulares."
} 
allowing investors who purchase the new shares to profit instantaneously from the difference between the discounted purchase price and the market price. ${ }^{82,}$

Trocando em miúdos, este tipo de poison pill visa aumentar o número de ações da companhia para tanto diluir o capital desta quanto para aumentar a quantidade de ações que o potencial adquirente terá que comprar para ter o seu controle. Além disso, garante aos acionistas préexistentes da companhia a possibilidade de aumentar sua participação, pois lhes são vendidas estas ações por um preço abaixo do valor de mercado.

Segue entendimento doutrinário sobre esta modalidade de poison pill:

“A companhia-alvo permite aos seus acionistas com exclusão do ofertante, a possibilidade de: (i) adquirirem ações de emissão da companhia alvo, mantidas em tesouraria, por um preço inferior ao valor de mercado, dificultando-se a obtenção do controle; ou (ii) subscreverem ações a serem emitidas em aumento do capital social da companhia-alvo, por valores inferiores aos praticados pelo mercado. ${ }^{83}$,

No nosso ordenamento jurídico as medidas defensivas do tipo flip in poderiam ser utilizadas mediante bônus de subscrição ${ }^{84}$ e plano de opção de compra $^{85}$. Essas seriam as únicas hipóteses que poderíamos conceber a implementação desta medida defensiva.

82 Disponível em: http://www.investopedia.com/terms/f/flip-in-poison-pill.asp. Acessado em 20/10/2015. Tradução livre: "um tipo de poison pill a qual os acionistas já existentes, mas não os acionistas adquirentes, podem comprar ações da companhia alvo com desconto. A poison pill flip in dilui o valor das ações compradas pela companhia adquirente, uma vez que coloca no mercado uma grande quantidade de ações ao mesmo tempo que permite aos investidores que as compram ganhos instantâneos baseados na diferença entre o desconto do preço de compra e o valor de mercado das ações."

83 NASCIMENTO, João Pedro Barroso do. Medidas defensivas à Tomada de Controle de Companhias. Editora Quartier Latin do Brasil. 2011, p.142-143

84 "Analisando o bônus de subscrição à luz das táticas defensivas contra tomadas de controle, especialmente os planos de poison pill na modalidade flip in, observa-se que estes podem servir como mecanismo adotado para dificultar a tomada de controle da companhia-alvo, mediante aumento de seu capital social: (i) diluindo a participação acionária detida pelo potencial adquirente interessado na tomada de controle; e/ou (ii) aumentando a quantidade de ações que o ofertante deverá adquirir para tomar o controle da companhia-alvo; paralelamente elevando a participação acionária detida pelos acionistas interessados na manutenção do controle na companhia-alvo. NASCIMENTO, João Pedro Barroso do. Medidas defensivas à Tomada de Controle de Companhias. Editora Quartier Latin do Brasil. 2011, p.143-144.

85 “A Lei 6.404/76 em seu artigo 168, $\S 3^{\circ}$, estabelece que, dentro do limite do capital autorizado, o estatuto social pode prever que a companhia, de acordo com o plano aprovado pela assembleia geral, outorgue opção de compra aos seus administradores, empregados ou pessoas naturais que prestem serviços à companhia ou para a sociedade sob seu controle. [...] Da mesma forma que ocorre com o bônus de subscrição, a opção de compra de ações também assegura ao seu titular o direito de subscrever futuramente ações da companhia, por um preço de emissão previamente 


\subsubsection{Flip over}

Outra modalidade de poison pill é a de flip over. Esta cláusula garante aos acionistas da companhia alvo o poder de comprarem as ações da companhia adquirente por um preço abaixo do valor de mercado. Neste caso, o controle do adquirente passaria aos acionistas da companhia alvo.

Segue entendimento de Luís Menezes Leitão sobre a poison pill de flip over: "a sociedade visada concede aos seus acionistas o direito de adquirir ações do próprio ofertante a um preço mais reduzido após a aquisição, procurando assim transferir o controlo do ofertante para os seus próprios acionistas. ${ }^{86,}$

Este tipo de mecanismo é usado após uma empresa adquirir o controle da companhia alvo e decidir praticar um ato societário de concentração, como uma fusão ou incorporação, por exemplo. Nesses casos, seriam atribuídas aos acionistas da companhia alvo as ações da nova empresa por um preço menor do que o seu valor de mercado. Estes direitos seriam exequíveis juridicamente porque "os países em que há a adoção de poison pills na modalidade flip over, notadamente os EUA, adotam o pressuposto de que a companhia resultante da operação de concentração empresarial será sucessora universal, em todos os direitos e obrigações das companhias extintas em tal operação, e, consequentemente, será responsável por honrar o direito de conversão atribuído aos acionistas da companhia-alvo. ${ }^{87,}$

estabelecido à época da outorga da opção de compra.[...] Os aumentos de capital realizados para exercício de opção de compra, assim como aqueles realizados para o exercício do bônus de subscrição, serão efetivados sem a existência de direito de preferência aos demais acionistas, de acordo com o $\S 3^{\circ}$ do artigo 171 da Lei $6.404 / 76$. No caso das opções de compra, por suas próprias características e por destinar-se a beneficiários específicos, o direito de preferencia não se aplica nem mesmo na outorga da opção de compra. NASCIMENTO, João Pedro Barroso do. Medidas defensivas à Tomada de Controle de Companhias. Editora Quartier Latin do Brasil. 2011, p.145147.

${ }^{86}$ LEITÃ̃, Luís Manuel Teles de Menezes. As medidas defensivas contra uma oferta pública de aquisição hostil. $O$ direito. Ano 138, t.III, Coimbra: Almedina, 2006, p.463.

87 NASCIMENTO, João Pedro Barroso do. Medidas defensivas à Tomada de Controle de Companhias. Editora Quartier Latin do Brasil. 2011, p.148 
A utilização desta medida defensiva não seria possível no Brasil. Apesar de nosso ordenamento jurídico ter o mesmo raciocínio acima exposto, de que a nova empresa sucederá em todos os direitos e obrigações a companhia incorporada (artigo 227 Lei 6.404/76), nada obriga que esta regra seja respeitada antes da incorporação e, além disso, o nosso ordenamento proíbe tratamentos diferenciados entre os acionistas de uma mesma empresa. Dessa forma, seria inviável que esta cláusula fosse implementada nas companhias brasileiras.

\subsubsection{Cavaleiro Branco (White Knight)}

A proteção contra tomadas hostis de controle conhecida como cavaleiro branco ou, como é chamada nos Estado Unidos de White Knight, é definida no Black's Law Dictionary como “a person or Corporation that rescues the target of an unfriendly corporate takeover, esp. by acquiring a controlling interest in the target coporation or by making a competing tender offer. ${ }^{88, "}$

O cavaleiro branco seria um terceiro, amigo dos administradores e/ou acionistas da companhia alvo de uma oferta hostil de controle, que seria convidado para realizar também uma oferta de aquisição de controle. Isso representaria mais uma oferta na mesa e faria com que os administradores escolhessem a que lhes fosse mais benéfica.

Este tipo de mecanismo já foi relatado no filme "Wall Street - Poder e Cobiça" ${ }^{\text {" }}$, no qual o personagem de Michael Douglas faz uma oferta hostil de aquisição de controle contra a companhia Bluestar e, para se defender desta operação, empregados da companhia vão procurar um cavaleiro branco e encontram o "Sir. Larry Wildman" que faz uma oferta amigável à empresa.

\footnotetext{
${ }^{88}$ Tradução livre do trecho: "uma pessoa ou companhia que resgata uma companhia alvo de tomada hostil de aquisição de controle, mediante a aquisição de seu controle ou fazendo uma oferta concorrente.'(GARNER, Bryan A. Black's Law Dictionary. $4^{\text {th }}$ Pocket ed. West Group, 2001, verbete poison pill, p. 828)

${ }^{89}$ WALL STREET. Direção de Oliver Stone. EUA: $20^{\text {th }}$ Century Foz Film Corporation. 126 minutos, 1987. Nome da versão brasileira: "Wall street - poder e cobiça."
} 
Este mecanismo foi recentemente utilizado também pela Gucci contra uma oferta hostil de aquisição de controle da Louis Vuitton Moet Henessy (LVMH). Por meio de escalada acionária que começou em meados de 1999, a LVMH tentou adquirir o controle da concorrente Gucci através de uma companhia fantasma. Primeiramente, a LVMH alegou que estas escaladas seriam apenas passivas e estratégicas e que não representavam uma oferta de fato à Gucci. Contudo, devida a fama do Chairman da LVMH, a Gucci sabia que aquela operação era uma oferta hostil de controle. Com base neste raciocínio, a Gucci começou a procurar mecanismos para impedir a aquisição do controle pela sua maior concorrente. Ela poderia negociar com a LVMH, o que limitaria o controle da LVMH sobre a Gucci, ou ela poderia encontrar uma defesa prevista em seu Estatuto Social, o que impediria a potencial aquisição de controle pela LVMH das ações da Gucci, ou a Gucci poderia encontrar um cavaleiro branco que compraria ações suficientes para impedir a aquisição de controle da LVMH e que agiria em conjunto com o seu Conselho de Administração. Todavia, seu Estatuto Social não apresentava nenhuma defesa substantiva, pelo contrário, ele facilitava tomadas hostis de controle. A única defesa que ele apresentava era uma cláusula de paraquedas dourados para proteger Tom Ford, diretor criativo, e Domenico De Sole, presidente e CEO da empresa.

Neste cenário, a primeira manobra feita pela Gucci foi fazer uso do mecanismo chamado White Squire (ela deu a opção de compra para os seus empregados de suas ações) para diluir a participação da LVMH na companhia alvo, medida que ficou conhecida como Employee Stock Ownership Plan (ESOP), emitindo 37 milhões de ações ordinárias. A LVMH que antes tinha $34.4 \%$ das ações da empresa ficou com apenas $25.6 \%$, após a operação.

Esta prática foi muito controvertida, pois era ilegal nos Estados Unidos, onde sua lei comercial impede que uma companhia emita ações repentinamente e com valor acima de $20 \%$ do seu capital social. Não 
obstante, como a Gucci era uma empresa estrangeira, ela não estava obrigada por essa lei. De qualquer forma, a LVMH entrou com uma ação contra a Gucci no Poder Judiciário da Holanda, sede da Gucci, alegando que a ESOP era ilegal porque seu único objetivo era impedir a LVMH de adquirir mais ações e não tinha nenhum benefício para os empregados. Já a Gucci alegou que a ESOP foi implementada porque o Conselho de Administração estava protegendo o futuro da companhia, os seus interesses e sua independência, bem como seus empregados e administradores.

Em março de 1999, a Corte decidiu por suspender os direitos de voto da LVMH e as ações emitidas através do ESOP até uma futura audiência a ser realizada em maio de 1999. Ademais, a Corte Holandesa ordenou que a LVMH e a Gucci conversassem seriamente sobre como resolver esta disputa. Apesar da Corte ter alegado que a aplicação ou não da ESOP era duvidosa, isso fez com a Gucci ganhasse mais tempo para neutralizar a LVMH.

A companhia alvo precisava de outra medida defensiva e, destarte, passou a procurar um White Knight. Isto posto, em 12 de março de 1999, ela fez um acordo com o grupo francês Pinault-Printems-Rédoute (PPR) que aceitou fazer uma oferta concorrente a da LVMH. O acordo incluía a compra de $40 \%$ das ações da Gucci por 2.9 bilhões de dólares. Neste acordo, as suas ações estavam avaliadas em \$75,00 e esta manobra diminuiria a participação acionária da LVMH de $34,4 \%$ para $21 \%$.

Enquanto isso, a LVMH tentou negociar uma oferta de aquisição das ações da Gucci pelo valor de $\$ 81,00$ por ação e, ao saber do acordo dela com a PPR, aumentou esse valor para $\$ 85,00$.

Em maio de 1999, a Corte julgou contra a LVMH e declarou que o acordo entre a Gucci e a PPR era legal. A Corte também invalidou a emissão de ações da Gucci por meio do ESOP. Neste cenário, o acordo entre a Gucci e a PRP se manteve e a LVMH apelou da decisão.

Em 28 de setembro de 2000, a Corte Suprema Holandesa sentenciou que a Corte de Primeira Instância não investigou propriamente as práticas 
de gestão da Gucci quando aprovou a sua aliança com a PPR. Ela deveria ter analisado se este acordo feriria os interesses dos acionistas minoritários. Incapaz de resolver este conflito, a Corte Holandesa manteve esta disputa por anos sem resolvê-la.

Devido à morosidade do processo e sem esperanças que ele pudesse ser resolvido, a Gucci e a LMVH, enfim, entraram em um acordo: "In September 2001, LVMH and Gucci finally came to an out of court agreement, with PPR purchasing 8,579,337 of LVMH's Gucci shares. PPR purchased a little over $40 \%$ of LVMH's Gucci shares. This leaves PPR with over $51 \%$ of the Gucci shares and LVMH with $12 \%$ in its competitor. This agreement ended all litigation. PPR agreed to buy the LVMH shares for \$94 a share, while Gucci agreed to pay a special $\$ 7$ cash dividend to all nonPPR shareholders. Similarly, the Agreement set April 2004 as a date when "Gucci shareholders have the right, but not the obligation to put their share to PPR at $\$ 101.50$ a share." 90,".

Apesar do White Knight ser um mecanismo de defesa amplamente usado, ele as vezes não é operado no melhor interesse da companhia e apenas como uma medida para impedir aquisições hostis. Muitas vezes, para conseguir um cavaleiro branco, as empresas garantem alguns benefícios para seus "salvadores" que fazem com que a relação negocial fique desequilibrada ou até mesmo vendem suas ações por um preço mais baixo apenas para garantir que um terceiro amigável irá adquirir o controle de sua companhia.

No Brasil, tal medida defensiva não só não seria vedada, como está prevista na Lei 6.404 no artigo 262 e na Instrução CVM 361/02 com o nome de oferta pública concorrente. João Pedro Barroso do Nascimento afirma que "a atuação do administrador em buscar outras opções de ofertas públicas paralelamente à tentativa de tomada de controle da companhia é,

\footnotetext{
${ }^{90}$ LOPEZ, Ernesto Adolfo Hernandez. Bag Wars and Bank Wars, the Gucci and Banque National de Paris Hostile Bids: European Corporate Culture Responds to active Shareholders. Fordham Journal of Corporate \& Financial Law. v.9, $n^{\circ}$ 1, p. 127-190, 2003. Disponível em SSRN: $<$ http://ir.lawnet.fordham.edu/cgi/viewcontent.cgi?article $=1138 \&$ context=jcfl $>$. Acessado em $20 / 10 / 2015$.
} 
em nossa opinião, inclusive uma tarefa decorrente dos deveres legais impostos pelos artigo 153 a 158 da Lei 6.404/76 aos administradores da companhia." $" 91$

\subsubsection{Jóia da Coroa (Crown Jewel) ${ }^{92}$}

Esse mecanismo de defesa consiste na alienação de ativos relevantes da companhia-alvo (joias da coroa) para um terceiro com o intuito de tirar o atrativo daquela companhia para o ofertante.

Esta medida deve ser analisada com muita cautela no nosso ordenamento jurídico, pois ela pode ir contra o melhor interesse da companhia. Esta alienação, se feita fora dos limites impostos pelo mercado, pode não estar em conformidade com os deveres expressos nos artigos 153 a 158 da Lei 6.404/76, dado que não estará alinhada aos fins e interesse da companhia alvo. Destarte, caso haja necessidade de fazer uso desse mecanismo, é necessário uma sólida justificativa demonstrando que tal medida atende ao interesse social da empresa.

\section{Afirma Carlos Martins Neto:}

"o ativo a ser alienado pode ser considerado relevante pelo potencial adquirente, mas não estar relacionado à atividade principal da companhia. Nesse caso, em principio, não haveria qualquer óbice para alienação do ativo, sendo essa venda inclusive recomendada por Calixto Salomão Filho, uma vez que "evita um potencial desvirtuamento da atividade social futura em função dos interesses do adquirente ${ }^{93, .} ., 94$

De qualquer forma, para evitar questionamentos perante o poder judiciário, a companhia alvo tem que apresentar argumentos muito fortes e

\footnotetext{
91 NASCIMENTO, João Pedro Barroso do. Medidas defensivas à Tomada de Controle de Companhias. Editora Quartier Latin do Brasil. 2011, p.169

92 O Black's Law Dictionary define Crown Jewel como: “a company's most valuable asset, esp. as valued when the company is the subject of a hostile takeover. A common antitakeover device is for the target company to sell its Crown Jewel to a third party so that the company will be less attractive to an unfriendly suitor." (GARNER, Bryan A. Black's Law Dictionary. $4^{\text {th }}$ ed. West Group, 2001, verbete crown jewel, p. 384)

93 SALOMÃO FILHO, Calixto. O novo direito societário. $3^{\text {a }}$ ed. São Paulo: Malheiros, 2006, p.149.

${ }^{94}$ NETO, Carlos Martins. Dispersão acionária, tomada hostil de controle e poison pills: breve reflexões. Disponível em: <http://www.bocater.com.br/wp-content/uploads/2013/10/artigo-201009.pdf $>$. Acessado em 28/09/2015.
} 
consolidados para justificar a utilização da medida defensiva "Crown Jewel", demonstrando que está agindo no melhor interesse da sociedade e que tal prática irá trazer benefícios e lucros para a companhia-alvo.

\subsubsection{Pac-man}

A defesa pac-man ${ }^{95}$ seria uma espécie de contra-ataque à oferta hostil de tomada de controle da companhia alvo. A companhia alvo faz uma contraoferta ao ofertante para adquirir as ações da companhia do potencial adquirente. Este mecanismo ganhou esse nome devido ao jogo de vídeo game que ficou amplamente famoso nos anos 80 .

É válido ressaltar que o mecanismo pac-man não é uma oferta concorrente, mas sim, uma nova oferta originária em que as partes, apesar de serem as mesmas, ocupam polos distintos.

"É importante especificar que a defesa pac-man não é uma oferta pública concorrente. Trata-se de duas ofertas públicas distintas. Enquanto a oferta concorrente tem por objeto a companhia-alvo simultaneamente à(s) outra (s) oferta (s) pública (s) de aquisição de controle da companhia-alvo, a defesa pacman é uma oferta pública realizada pela companhia-alvo tendo objetivo adquirir o controle da companhia que estiver, concomitantemente, tentando adquirir o seu controle. ${ }^{96,}$

À vista disso, não seria aplicável a este tipo de defesa as imposições relativas à oferta concorrente, uma vez que são duas ofertas diferentes e que o objeto são duas companhias distintas e as partes ocupam polos diferentes na operação. Por conseguinte, consideramos equivocada a opinião de VeraHelena de Mello Franco que alega que ambas “estão sujeitas aos mesmos requisitos e procedimentos da oferta com que concorre."97

\footnotetext{
${ }^{95}$ O Black's Law Dictionary define Pac-man defense como: "an aggressive antitakeover defense by which the target company attempts to take over the bidder company by making a cash tender offer for the bidder company's shares. The name derives from a video game popular in the 1980s, the object of which was to gobble up the enemy. This defense is seldom used today." (GARNER, Bryan A. Black's Law Dictionary. $4^{\text {th }}$ ed. West Group, 2001, verbete pac man defense, p. 1133) 96 NASCIMENTO, João Pedro Barroso do. Medidas defensivas à Tomada de Controle de Companhias. Editora Quartier Latin do Brasil. 2011, p.176

${ }^{97}$ FRANCO, Vera Helena de Mello. Considerações sobre as ofertas públicas para aquisição de ações (OPAs): estado atual da questão. RDM. São Paulo: Malheiros, $\mathrm{n}^{\circ}$ 144, p. 16-58, out./dez. 2006, p. 29)
} 
Ultrapassadas as ponderações acima, no nosso ordenamento jurídico, seria possível aplicar a defesa pac-man, pois ela seria regida pelas regras de qualquer oferta pública de aquisição de controle. Contudo, a operação só seria caracterizada de fato como um pac-man, uma vez que a companhia ofertante fosse aberta e tivesse dispersão acionária para que fosse possível a aquisição do seu controle.

\subsubsection{Paraquedas Dourado (Golden Parachute)}

A medida defensiva conhecida como Golden Parachute garante aos administradores de uma determinada companhia uma indenização econômica alta caso o controle da companhia alvo seja transferido. Esta medida visa tanto impedir tomadas hostis de controle por gerar um ônus a mais para o potencial adquirente, como também visa garantir a estabilidade do controle, retendo seus funcionários estratégicos, dado que, em uma mudança de controle, os administradores normalmente são destituídos. ${ }^{98}$

O Black's Law dictionary define Golden Parachute como:

\footnotetext{
"an employment-contract provision that grants an upper-level executive lucrative severance benefits -including long term salary guarantees or bonuses - if control of the company changes hands (as by a merger)."
}

Este mecanismo tem alguns inconvenientes que são objeto de grande debate nos Estados Unidos. Primeiro, o golden parachute impediria que o controle da companhia fosse mudado e, caso esse controle não fosse exercido no melhor interesse da empresa e de acordo com o business judgement rule ele não seria renovado. Segundo, os funcionários que fossem beneficiados com esta cláusula poderiam até mesmo incentivar uma mudança de controle para que eles pudessem usufruir de sua compensação.

No Brasil, há controvérsia se este mecanismo seria legal ou não. João Pedro Barroso do Nascimento reputa ser lícita esta proteção, uma vez

\footnotetext{
${ }^{98}$ CLARK, Robert Charles. Corporate Law. New York. Aspen Publishers, 1986, p. 577.

${ }^{99}$ Tradução livre do trecho: "uma cláusula em um contrato de emprego que garante aos executivos de alto nível benefícios lucrativos se o controle da companhia mudar de mãos."(GARNER, Bryan A. Black's Law Dictionary. $4^{\text {th }}$ Pocket ed. West Group, 2001, verbete golden parachute, p. 336)
} 
respeitados a função social do contrato, a boa fé objetiva (art. 2035 Código Civil) e os requisitos previstos nos artigos 153 a 157 da Lei 6.404/76. Segue seu entendimento:

\begin{abstract}
"Parece-nos até certo ponto saudável e alinhado com o sistema pátrio, a adoção de medidas que visem a manutenção da estabilidade na condução dos negócios da companhia-alvo, mesmo diante de potencial tomada de controle, sendo que o paraquedas dourado contribuiria neste sentido. Todavia, tal defesa não deve ser utilizada para perpetrar abusos e/ou propiciar favorecimentos indevidos de administradores e profissionais estratégicos. A apuração do equilíbrio quanto ao conteúdo do programa de retenção de executivos deve ser feita em cada caso concreto." 100
\end{abstract}

Já Carlos Augusto Silveira Lobo, alega que os Golden Parachutes são ilegais, visto que são uma "atribuição injustificada aos administradores de opções de compra de ações, bônus, gratificações em dinheiro, enormes honorários e outras vantagens extraordinárias a serem pagas no caso de serem exonerados."

\title{
4.2.6. Medidas defensivas estatutárias
}

As medidas defensivas estatutárias são os mecanismos amplamente utilizados no Brasil contra tomadas hostis de controle da companhia. As companhias brasileiras colocam em seus estatutos cláusulas que visam impedir as tomadas hostis de controle ao estipularem a obrigatoriedade de realização de oferta pública de ações, uma vez que um percentual mínimo de ações é atingido.

Segue um exemplo de cláusula estatutária de proteção à dispersão acionária:

"Qualquer acionista que adquira ou se torne titular de ações de emissão da
companhia, em quantidade igual ou superior a X\% do total de ações de emissão,
excluídas para os fins deste cômputo as ações em tesouraria, deverá, no prazo de
30 (trinta) dias a contar da data de aquisição ou do evento que resultou na
titularidade de ações em quantidade igual ou superior a X\% do total de ações de

100 NASCIMENTO, João Pedro Barroso do. Medidas defensivas à Tomada de Controle de Companhias. Editora Quartier Latin do Brasil. 2011, p.179

101 LOBO, Carlos Augusto da Silveira. Sociedades coligadas, controladores e controladas. In: LAMY FILHO, Alfredo; BULHÕES PEDREIRA, José Luiz. Direito das companhias. V.2. Rio de Janeiro: Forense, 2009, p. 2034-2035 
emissão da companhia, realizar ou solicitar o registro de uma oferta pública de aquisição de ações para aquisição da totalidade das ações de emissão da Companhia. O preço de aquisição de cada ação de emissão da companhia não poderá ser inferior ao maior valor entre (i) X\% da cotação unitária mais alta atingida pelas ações de emissão da companhia durante o período de $\mathrm{X}$ meses anterior à realização da oferta em qualquer bolsa de valores em que as ações da companhia foram negociadas; (ii) X\% do preço unitário mais alto pago pelo acionista adquirente durante o período de $\mathrm{X}$ meses anterior à realização da oferta para uma ação ou lote de ações de emissão da companhia; e (iii) o valor econômico apurado em laudo de avaliação." 102

Estas cláusulas tornam obrigatória a realização de OPA à medida que um terceiro ou acionista adquira um percentual das ações de emissão da companhia.

“A finalidade dessa disposição estatutária é, de certa forma, proteger a companhia contra ofertas hostis, ao tornar demasiadamente oneroso o aumento de participação acionária para além de determinados limites estatutariamente previstos. ${ }^{103,}$

No Brasil, essa disposição estatutária está presente também em estatutos de companhias que não tem dispersão acionária, como será demonstrado no item 6 deste trabalho. As companhias quando começaram a pulverizar seu capital na bolsa, passaram a se utilizar desse mecanismo em seus estatutos com medo de perder o controle de suas empresas. Luiza Rangel de Moraes disserta sobre o assunto:

"No Brasil, as técnicas de defesa (poison pills) vão desde as medidas adotadas por companhias com acionista controlador definido, tendo por objetivo evitar a concentração de liquidez em um único acionista, até as que se destinam a prevenir uma tomada de controle hostil, em companhias com controle societário pulverizado. ${ }^{104,}$

Além deste modelo de cláusula, algumas companhias adotaram mecanismos para tornarem imutáveis estas medidas de proteção contra tomadas hostis de controle. Elas visavam vedar a mudança dessas cláusulas estatutárias de proteção impondo que, caso os acionistas votassem a favor

\footnotetext{
${ }^{102}$ Memorando para o Colegiado da CVM elaborado por Marcos Barbosa Pinto e Otavio Yazbek (deu origem ao parecer de Orientação 35).

103 NASCIMENTO, João Pedro Barroso do. Medidas defensivas à Tomada de Controle de Companhias. Editora Quartier Latin do Brasil. 2011, p.152

${ }^{104}$ MORAES, Luiza Rangel de. A pulverização do Controle de Companhias Abertas. RDB. São Paulo: RT, nº 32, p. 49-84, abr.jun. 2006, p.77
} 
de sua supressão ou alteração eles tivessem que realizar oferta pública de ações.

"O que se tem observado, contudo, é que a posion pill pretende adquirir, em muitos casos, feições de imutabilidade, de verdadeira cláusula "pétrea", evidenciando aquela primeira questão de utilizá-las como mecanismo jurídico de perpetuação de um determinado grupo no controle da companhia. São exemplos desse tipo aberrante as cláusulas estatutárias que punem aqueles acionistas que votarem em Assembleia Geral pela alteração ou exclusão, obrigando-os a realizar a OPA referente a todas as ações de emissão da companhia, sendo esta a própria oferta prevista na cláusula poison pill, pois constrange o exercício do direito de voto do acionista, o qual deverá ser manifestado, sempre, de forma livre e em consonância com o interesse social."

Estas cláusulas pétreas geraram grandes críticas por parte da doutrina, até que, em 2009, a CVM deu parecer sobre o assunto informando que "não aplicará penalidades, em processos administrativos sancionadores, aos acionistas que, nos termos da legislação em vigor, votarem pela supressão ou alteração da cláusula de proteção à dispersão acionária, ainda que não realizem a oferta pública prevista na disposição acessória."106

As cláusulas pétreas nitidamente violam nossos dispositivos legais e não estão em conformidade com o melhor interesse da companhia. É evidente a afronta ao artigo 115 da Lei das S.A., pois o voto deve ser livre, sem constrangimento ou restrição, por isso, não pode ser exercido em desacordo com o interesse da companhia.

Em relação aos artigos 121 c/c 122, I, que tratam da soberania da Assembleia Geral e de sua competência para alterar o estatuto, fica claro que ao limitar o direito a voto dos sócios nas suas deliberações, se estaria diminuindo seus poderes. Neste ponto, segue entendimento da doutrina:

"A respeito dos artigos 121 e 122, inciso I, da Lei no $6.404 / 76$, concordamos
parcialmente com as conclusões da CVM. De fato, a existência de sanção
estatutária que imponha ônus pecuniário ao acionista que votar favoravelmente à
alteração e/ou exclusão da cláusula de proteção à dispersão acionária representa
uma inadequada limitação ao voto atribuído ao acionista. A soberania da
Assembleia Geral não é limitada por tal disposição, permanecendo a Assembleia
Geral como órgão supremo da companhia. O que é limitado por tal disposição são
os direitos políticos atribuídos aos acionistas, notadamente o direito de voto, com

${ }^{105}$ CARVAlHOSA, Modesto; CASTRO, Rodrigo R. Monteiro de; e ARAGÃO, Leandro Santos de. Direito Societário: desafios atuais. Quartier Latin. 2009. P. 26

${ }^{106}$ SANTOS, Maria Helena. Parecer de Orientação no 36/2009 CVM. 
o reconhecimento permanente de que a imutabilidade da regra estatutária é a vontade social, com a consequente redução da importância do voto exercido pelo acionista." 107

Por fim, em relação ao artigo $129, \S 1^{\circ}$ da referida Lei, a CVM pondera que a prática adotada pelas cláusulas pétreas é vedada por este artigo, uma vez que "o efeito prático das disposições acessórias é exigir unanimidade, ou quase unanimidade, para que a cláusula de proteção à dispersão acionária possa ser suprimida. Indiretamente, as disposições acessórias podem aumentar o quórum previsto em lei para essa deliberação social."

Francisco Mussnich conclui sobre o assunto:

"Esta limitação do seu direito de voto acaba por desencadear diversas ofensas frontais a princípios basilares do direito societário e normas legais de ordem pública, evidenciando as cláusulas pétreas como dispositivos flagrantemente ilegítimos e ilegais. ${ }^{108,}$

Diante disso, resta evidente que as cláusulas pétreas são uma afronta ao nosso ordenamento jurídico e não devem ser inseridas nos estatutos sociais das companhias, lhe sendo permitido apenas a utilização de medidas defensivas contra a tomada hostil de controle mediante a obrigatoriedade de realização de oferta pública de aquisição de ações.

107 NASCIMENTO, João Pedro Barroso do. Medidas defensivas à Tomada de Controle de Companhias. Editora Quartier Latin do Brasil. 2011, p.159

${ }^{108}$ MUSSNICH, Francisco Antunes Maciel. Análise prática e considerações sobre a realidade e a aplicação das medidas de proteção à tomada hostil de controle nos estatutos sociais das companhias abertas brasileiras (Brazilian pills). In: SILVA, Alexandre Couto. Direito Societário, Estudos sobre a lei de sociedades por ações. Editora Saraiva, 2013. P. 266. 


\section{Análise de Casos}

Neste trabalho se faz importante uma análise de casos envolvendo ofertas hostis de tomada de controle da companhia e medidas defensivas contra aquisições tanto no ordenamento jurídico americano quanto no ordenamento jurídico nacional.

Serão analisados "leading cases" $" 109$ do direito americano e do direito brasileiro com o objetivo de verificarmos como os tribunais brasileiros e americanos estão julgando as questões inerentes a estas operações.

\subsection{Unocal Corp. V. Mesa Petroleum Co.}

Este foi um dos leading cases mais importantes, pois foi o primeiro caso julgado pelo judiciário americano a favor das medidas defensivas contra tomadas hostis de controle. ${ }^{110}$

A Mesa detinha 13\% das ações de emissão da Unocal e em 1985 tentou tomar o controle desta companhia mediante uma oferta de $37 \%$ das ações da companhia por $\$ 54,00$ por ação, quantidade suficiente para lhe garantir o controle da companhia alvo. Além disso, para as ações remanescentes, a Mesa as compraria com pagamento em valores mobiliários.

O conselho de administração da Unocal se reuniu junto com advogados e economistas da Goldman Sachs \& Co. para tentar encontrar uma medida defensiva contra esta oferta. Após muitas discussões, eles

\footnotetext{
109 Leading cases são casos emblemáticos que pela sua importância viraram jurisprudências e precedentes fortes e consolidados. O Black's Law Dictionary define leading case como: “A judicial decision that first definitely settled an important legal rule or principle and that has since been often and consistently followed. An important, often the most important, judicial precedent on a particular legal issue."

${ }^{110}$ Martin Lipton expressa a importância desse caso para o direito Americano: "This is probably the single most important corporate law case to come before the courts in years... Legal challenges [to the pill] have proliferated [throughout the United States]. But the [Household] case in Delware is the crucial one. Because so many companies are incorporated there, and because the court is widely respected, its decision will set the tone for rulings in other state and federal courts." LIPTON, Martin. Pills, polls and professors Redux. The University of Chicago Law Review. Volume 69. Summer 2002. Number 3. P. 1047.
} 
decidiram realizar uma oferta concorrente, tendo oferecido $\$ 72$ por ação

para os acionistas de sua companhia, excluindo a Mesa Petroleum.

Quando isso se tornou público, a Mesa entrou com uma ação na

Corte de Delware, alegando que essa medida feriria o princípio da igualdade entre os acionistas, uma vez que eles tinham sido excluídos da oferta.

A Suprema Corte decidiu pela Unocal alegando que ela agiu no melhor interesse da companhia e de seus administradores, em conformidade com o business judgement rule e que a medida defensiva foi plausível diante da oferta hostil de aquisição de controle que eles estavam submetidos.

Segue parte do julgado:

"A further aspect is the element of balance. If a defensive measure is to come within the ambit of the business judgment rule, it must be reasonable in relation to the threat posed. This entails an analysis by the directors of the nature of the takeover bid and its effect on the corporate enterprise. Examples of such concerns may include: inadequacy of the price offered, nature and timing of the offer, questions of illegality, the impact on "constituencies" other than the shareholders (i.e., creditors, employees, and perhaps even the community generally), the risk of nonconsummation, and the quality of securities being offered in the exchange.

(...)

In conclusion, there was directorial power to oppose the Mesa tender offer, and to undertake a selective stock exchange made in good faith and upon a reasonable investigation pursuant to a clear duty to protect the corporate enterprise. Further, the selective stock repurchase plan chosen by Unocal is reasonable in relation to the threat that the board rationally and reasonably believed was posed by Mesa's inadequate and coercive two-tier tender offer. Under those circumstances the board's action is entitled to be measured by the standards of the business judgment rules. Thus, unless it is shown by a preponderance of the evidence that the directors' decisions were primarily based on perpetuating themselves in office, or some other breach of fiduciary duty such as fraud, overreaching, lack of good faith, or being uninformed, a Court will not substitute its judgment for that of the board. (...)

With the Court of Chancery's findings that the exchange offer was based on the board's good faith belief that the Mesa offer was inadequate, that the board's action was informed and taken with due care, that Mesa's prior activities justify a reasonable inference that its principle objective was greenmail, and implicitly, that the substance of the offer itself was reasonable and fair to the corporation and its stockholders if Mesa were included, we cannot say that Unocal directors have acted in such a manner as to have passed an "unintelligent and unadvised judgement (... $)^{111,}$

111493 A.2d 946 (Del. Supr., 1985), pp. 955, 958/959. 


\subsection{Moran v. Household International, Inc.}

Este caso foi de grande destaque nos Estados Unidos, pois teve muita repercussão e estabeleceu limites e regras importantes para o uso de medidas defensivas contra tomadas hostis de controle da companhia. "O caso teve grande repercussão, por ter sido a primeira ocasião em que os planos de poison pill, que haviam se tornado extremamente populares em companhias norte-americanas dotadas de dispersão acionária, seriam submetidos à discussão perante o Judiciário."

Em agosto de 1984, o Conselho de Adminsitração da Household International votou o chamado "Rights Plan". Este plano consistia, basicamente, na concessão aos seus acionistas de uma opção de compra mediante a implementação de uma poison pill de flip over, já estudada anteriormente. Eles estabeleceram dois eventos que poderiam acionar este direito: (i) o anúncio de oferta de aquisição de controle de pelo menos $30 \%$ das ações de emissão da Household e (ii) a aquisição de no mínimo $20 \%$ das ações da companhia por uma única companhia ou grupo.

Esta cláusula foi implementada antes que qualquer oferta tivesse sido feita e tinha o intuito de proteger a companhia contra futuras aquisições hostis. O maior acionista da Household era a Dyson-Kissner Moran Corporation que tinha como presidente John Moran. John Moran foi um dos administradores que votaram contra a implementação desta cláusula e, após sua aprovação, entrou na justiça para tentar impedir sua perpetuação.

A Corte de Delware entendeu que a poison pill era legítima, uma vez que a Household International agiu no melhor interesse da companhia. A Corte estabeleceu, nesse caso, como no caso da Unocal, que cabe ao conselho de administração determinar se a oferta pública de aquisição de ações da companhia alvo é benéfica ou não para sua companhia. Dessa forma, sendo guiados pela business judgement rule, podem e devem se preparar para uma possível oferta hostil para diminuir seu risco de tomar uma decisão sem um julgamento racional. 
"The business judgment rule is a "presumption that in making a business decision the directors of a corporation acted on an informed basis, in good faith and in the honest belief that the action taken was in the best interests of the company." Aronson v. Lewis, Del.Supr., 473 A.2d 805, 812 (1984) (citations omitted). Notwithstanding, in Unocal we held that when the business judgment rule applies to adoption of a defensive mechanism, the initial burden will lie with the directors. The "directors must show that they had reasonable grounds for believing that a danger to corporate policy and effectiveness existed.... [T] hey satisfy that burden 'by showing good faith and reasonable investigation...." Unocal, 493 A.2d at 955 (citing Cheff v. Mathes, 199 A.2d at 554-55). In addition, the directors must show that the defensive mechanism was "reasonable in relation to the threat posed." Unocal, 493 A.2d at 955. Moreover, that proof is materially enhanced, as we noted in Unocal, where, as here, a majority of the board favoring the proposal consisted of outside independent directors who have acted in accordance with the foregoing standards. Unocal, 493 A.2d at 955; Aronson, 473 A.2d at 815. Then, the burden shifts back to the plaintiffs who have the ultimate burden of persuasion to show a breach of the directors' fiduciary duties. Unocal, 493 A.2d at 958.

(...)

In addition, to meet their burden, the Directors must show that the defensive [1357] mechanism was "reasonable in relation to the threat posed". The record reflects a concern on the part of the Directors over the increasing frequency in the financial services industry of "boot-strap" and "bust-up" takeovers. The Directors were also concerned that such takeovers may take the form of two-tier offers.[14] In addition, on August 14, the Household Board was aware of Moran's overture on behalf of D-K-M. In sum, the Directors reasonably believed Household was vulnerable to coercive acquisition techniques and adopted a reasonable defensive mechanism to protect itself. ${ }^{12, "}$

Destarte, este julgado estabeleceu também que, para a implementação de uma medida defensiva, é necessário que os administradores e acionistas tenham amplo conhecimento daquilo que estão aprovando e os efeitos que possam decorrer deste mecanismo. Assim sendo, esses mecanismo de defesa não podem representar um impedimento absoluto para a tomada de controle, mas apenas uma medida que vai permitir uma maior negociação e estruturação da operação.

Segue a parte conclusiva do julgado:

"In conclusion, the Household Directors receive the benefit of the business judgment rule in their adoption of the Rights Plan.

The Directors adopted the Plan pursuant to statutory authority in 8 Del.C. $\$ \S$ 141, 151, 157. We reject appellants' contentions that the Rights Plan strips stockholders of their rights to receive tender offers, and that the Rights Plan fundamentally restricts proxy contests.

The Directors adopted the Plan in the good faith belief that it was necessary to protect Household from coercive acquisition techniques. The Board was informed as to the details of the Plan. In addition, Household has demonstrated that the

${ }^{112}$ Disponível em: <https://h2o.law.harvard.edu/collages/8890 $>$. Acessado em 30/09/2015 
Plan is reasonable in relation to the threat posed. Appellants, on the other hand, have failed to convince us that the Directors breached any fiduciary duty in their adoption of the Rights Plan.

While we conclude for present purposes that the Household Directors are protected by the business judgment rule, that does not end the matter. The ultimate response to an actual takeover bid must be judged by the Directors' actions at that time, and nothing we say here relieves them of their basic fundamental duties to the corporation and its stockholders. Unocal, 493 A.2d at 954-55, 958; Smith v. Van Gorkom, 488 A.2d at 872-73; Aronson, 473 A.2d at 812-13; Pogostin v. Rice, Del.Supr., 480 A.2d 619, 627 (1984). Their use of the Plan will be evaluated when and if the issue arises ${ }^{113}$ ",

\subsection{Mittal Steel Company v. Arcelor S.A. ${ }^{114}$}

O caso da Mittal Steel Company e da Arcelor foi emblemático no Brasil, pois garantiu que uma imposição estatutária fosse cumprida, bem como caracterizou a obrigação ou não de uma oferta pública de ações.

A Mittal Steel Company, empresa com sede na Holanda, adquiriu, por oferta pública de aquisição de ações, as ações de emissão da Arcelor, companhia aberta sediada em Luxemburgo, e com subsidiárias e valores mobiliários listados em diversas jurisdições, inclusive no Brasil, onde é controladora da Arcelor Brasil e da Acesita.

$\mathrm{O}$ artigo $8^{\circ}$ e $10^{\circ}$ do Estatuto social da Arcelor Brasil dispunham do seguinte:

"Art. 80 - A alienacão a título oneroso de bloco de acões que assegure a um acionista, a um grupo de acionistas sob controle comum ou vinculados por acordo de voto, o poder de controle da Companhia, direta ou indiretamente, tanto por meio de uma única operacão, como por meio de operacões sucessivas, deve ser contratada sob a condicão, suspensiva ou resolutiva, de que o adquirente do poder de controle obrigue-se a concretizar uma oferta pública de aquisicão das acões dos demais acionistas da Companhia, de forma a lhes assegurar tratamento igualitário àquele dado ao alienante.

$\$ 10$ - A transfereñcia de acões ou de direitos inerentes às acões da Companhia ou de outros títulos ou direitos relativos a valores mobiliários conversíveis em acões, de forma direta ou indireta, entre Pessoas Relacionadas, mesmo que implique na consolidacão do poder de controle em apenas um acionista, não constitui alienacão do poder de controle,

$5 / 11$

\footnotetext{
${ }^{113}$ Disponível em: <https://h2o.law.harvard.edu/collages/8890 > Acessado em 30/09/2015

114 Processo Administrativo CVM RJ-2006-6209/2006. Disponível em: $<$ http://www.cvm.gov.br/export/sites/cvm/decisoes/anexos/0003/5256-0.pdf $>$. Acessado em $30 / 09 / 2015$
} 
não dando causa, portanto, à obrigacão de realizar oferta pública nos termos do caput deste Artigo. Para fins desta Secão, Pessoa Relacionada" significa o controlador final da Companhia e as pessoas ou entidades, direta ou indiretamente, sob controle comum de tal controlador.

$\$ 2 o$ - O prazo, a documentacão e o procedimento da oferta mencionada nesta Secão deverão ser aqueles exigidos pela regulamentacão da Comissão de Valores Mobiliários aplicável a ofertas públicas por alienacão de controle que estiver em vigor na data da referida alienacão.

Art. $9 o$ - A oferta pública de aquisicão de acões a que se refere o caput do Artigo 8 o também será exigida quando houver cessão onerosa de direitos de subscricão de acões de outros títulos ou direitos relativos a valores mobiliários conversíveis em acões emitidos pela Companhia, que venha a resultar na alienacão de bloco de acões que assegure o poder de controle da Companhia.

Art. 10 - A oferta pública de aquisicão de acões a que se refere o Artigo 80 será também exigida caso uma pessoa, que não uma Pessoa Relacionada, adquira o poder de controle da Companhia por meio de aquisicão de acões de emissão do acionista controlador final da Companhia. Neste caso, a sociedade objeto da aquisicão do poder de controle ficará obrigada a declarar à Bolsa de Valores de São Paulo (Bovespa)" a mudanca em seu controle acionário e a sociedade adquirente deste ficará obrigada a declarar à Bovespa o valor atribuído à Companhia nessa alienacão."

Com base nessas disposições estatutárias, em $1^{\circ}$ de agosto de 2006, a SEP e a SRE deram entendimento de que a Mittal Steel, "adquirente do poder de controle indireto da Arcelor Brasil, tem o dever legal de cumprir a obrigacão estatutariamente prevista de realização de OPA para os acionistas minoritários da Companhia". Essa declaração tinha fulcro no parecer da Procuradoria Federal Especializada - PFE (MEMO/PFE-CVM/No 1004/06, de 31.08.2006) que alegava que a OPA decorreria do artigo 10 do estatuto social da Arcelor Brasil (e não do art. 254-A da Lei 6.404/76). "Tratando-se de compromisso decorrente de cláusula estatutária, a Procuradoria entende que a Oferta não é exigível no caso de Acesita S.A., cujo estatuto não contém tal disposição."

A Arcelor recorreu desta decisão alegando que a CVM não tinha competência, de acordo com a lei brasileira, para estabelecer obrigações que não estavam previstas em lei ou regulamentações. Além disso, o recorrente também explicou que o artigo $10^{\circ}$ do Estatuto Social da Companhia se refere à OPA prevista no artigo 254-A da Lei 6.404/76, que pressupõe uma alienação de controle, o que não foi o caso, pois a Arcelor S.A. tinha seu controle disperso na bolsa e ninguém detinha seu controle 
direto. Por isso, o artigo $10^{\circ}$ só serviria para sinalizar que: "não importa onde o controlador final esteja localizado, se a aquisição dessa entidade ocorrer, uma oferta pública será exigida".

Wladimir Castelo Branco proferiu voto a respeito do assunto dispondo que, com base nos artigos $4^{\circ}$, inciso IV, alínea "b", 9 $9^{\circ}$, inciso V, e $11, \S 4^{\circ}$, da Lei 6.385/76, a CVM estava "exercendo suas atribuições com a finalidade de proteger os titulares de valores mobiliários e os investidores de mercado contra atos ilegais de administradores e acionistas controladores." Afirma, ainda, "assim, seja por força das matérias previstas na Lei 6.404/76, seja por força do disposto na Lei 6.385/76, a CVM tem competência legal para exercer suas atribuições à luz de cláusulas estatutárias. $\mathrm{O}$ que foi escrito no estatuto tem que ser respeitado na prática, sem o que não há relacionamento possível entre acionistas, nem mercado de capitais."

Em relação ao alegado pelo Recorrente como justificativa da aplicabilidade do artigo $10^{\circ}$ do Estatuto Social da Companhia, esta não parece adequada para Wladimir que argumenta: "a única interpretação que me parece fazer sentido é a de que o art. $10^{\circ}$ previu para a Arcelor Brasil uma OPA inexistente na atual legislação para o caso de uma aquisição originária de controle de sua controladora final, conferindo aos acionistas minoritários da companhia brasileira o direito de "retirar-se" pelo mesmo preço oferecido aos acionistas de Arcelor. $\mathrm{O}$ fato de se falar em "aquisição de ações de emissão do acionista controlador final da Companhia" indicaria que se pensou mesmo na venda em oferta pública, o que faria sentido na estrutura de capital da Arcelor."

Ademais, ele conclui dizendo que uma violação ao estatuto social é uma ilegalidade como o desrespeito a uma lei. "Contanto que o estatuto esteja livre de vícios de vontade e de validade, deve ser seguido como se segue à lei e punido como à lei se pune." 


\section{Análise Prática: panorama das empresas listadas no segmento do Novo Mercado da BM\&FBovespa}

Neste capítulo, serão abordados dados tirados do site da BM\&FBovespa para embasar a conclusão deste trabalho e para analisar de forma prática a dispersão acionária no mercado de ações nacionais e como é feita a utilização de medidas defensivas contra tomadas hostis de controle das companhias. Como referência, segue o Anexo I elaborado com os dados da pesquisa.

As empresas analisadas são as 131 listadas no Novo Mercado da BM\&Fbovespa. Foi escolhido este segmento para o estudo, pois o capital destas empresas deve ser, obrigatoriamente, composto somente por ações ordinárias com direito a voto e pelo menos $25 \%$ de suas ações devem estar em circulação no mercado. Outrossim, este segmento tem o mais elevado padrão de governança corporativa o que garante uma maior divulgação e transparência nas suas atividade. ${ }^{115}$

Segue abaixo, a tabela com todas as empresas listadas no Novo Mercado:

\footnotetext{
${ }^{115}$ Seguem algumas regras do Novo Mercado relativas à governança corporativa e aos direitos dos acionistas: "O capital deve ser composto exclusivamente por ações ordinárias com direito a voto; No caso de venda do controle, todos os acionistas têm direito a vender suas ações pelo mesmo preço (tag along de 100\%); Em caso de deslistagem ou cancelamento do contrato com a BM\&FBOVESPA, a empresa deverá fazer oferta pública para recomprar as ações de todos os acionistas no mínimo pelo valor económico; O Conselho de Administração deve ser composto por no mínimo cinco membros, sendo $20 \%$ dos conselheiros independentes e o mandato máximo de dois anos; A companhia também se compromete a manter no mínimo $25 \%$ das ações em circulação (free float); Divulgação de dados financeiros mais completos, incluindo relatórios trimestrais com demonstração de fluxo de caixa e relatórios consolidados revisados por um auditor independente; A empresa deverá disponibilizar relatórios financeiros anuais em um padrão internacionalmente aceito; Necessidade de divulgar mensalmente as negociações com valores mobiliários da companhia pelos diretores, executivos e acionistas controladores." Disponível em: $<$ http://www.bmfbovespa.com.br/pt-br/servicos/solucoes-para-empresas/segmentos-delistagem/novo-mercado.aspx?idioma=pt-br>. Acessado em: 29/10/2015.
} 
Figura 1 - Lista das Empresas listadas no segmento do Novo mercado

\begin{tabular}{|c|c|}
\hline Razão Social & Nome de Pregão \\
\hline ALIANSCE SHOPPING CENTERS S.A. & ALIANSCE \\
\hline GAEC EDUCAÇÃO S.A. & ANIMA \\
\hline AREZZO INDÚSTRIA E COMÉRCIO S.A. & $\underline{\text { AREZZO CO }}$ \\
\hline ARTERIS S.A. & $\underline{\text { ARTERIS }}$ \\
\hline B2W - COMPANHIA DIGITAL & $\underline{\text { B2W DIGITAL }}$ \\
\hline BB SEGURIDADE PARTICIPAC̣ÕES S.A. & BBSEGURIDADE \\
\hline BIOSEV S.A. & BIOSEV \\
\hline BMFBOVESPA S.A. BOLSA VALORES MERC FUT & BMFBOVESPA \\
\hline BRASIL BROKERS PARTICIPACOES S.A. & BR BROKERS \\
\hline BRASIL INSURANCE PARTICIPAÇÕES E ADMINISTRAÇÃO S.A & BR INSURANCE \\
\hline BR MALLS PARTICIPACOES S.A. & BR MALLS PAR \\
\hline BRASIL PHARMA S.A. & BR PHARMA \\
\hline BR PROPERTIES S.A. & BR PROPERT \\
\hline BCO BRASIL S.A. & BRASIL \\
\hline BRASILAGRO - CIA BRAS DE PROP AGRICOLAS & BRASILAGRO \\
\hline BRF S.A. & BRF SA \\
\hline CCR S.A. & CCR SA \\
\hline CCX CARVÃO DA COLÔMBIA S.A. & $\underline{\text { CCX CARVAO }}$ \\
\hline CETIP S.A. - MERCADOS ORGANIZADOS & CETIP \\
\hline CIA HERING & CIA HERING \\
\hline CIELO S.A. & CIELO \\
\hline CIA SANEAMENTO DE MINAS GERAIS-COPASA MG & COPASA \\
\hline COSAN S.A. INDUSTRIA E COMERCIO & COSAN \\
\hline COSAN LOGISTICA S.A. & COSAN LOG \\
\hline CPFL ENERGIA S.A. & CPFL ENERGIA \\
\hline CPFL ENERGIAS RENOVÁVEIS S.A. & CPFL RENOVAV \\
\hline CR2 EMPREENDIMENTOS IMOBILIARIOS S.A. & $\underline{\mathrm{CR} 2}$ \\
\hline CSU CARDSYSTEM S.A. & CSU CARDSYST \\
\hline CVC BRASIL OPERADORA E AGÊNCIA DE VIAGENS S.A. & CVC BRASIL \\
\hline CYRELA COMMERCIAL PROPERT S.A. EMPR PART & CYRE COM-CCP \\
\hline CYRELA BRAZIL REALTY S.A.EMPREEND E PART & CYRELA REALT \\
\hline DIAGNOSTICOS DA AMERICA S.A. & DASA \\
\hline DIRECIONAL ENGENHARIA S.A. & DIRECIONAL \\
\hline $\begin{array}{l}\text { DURATEX S.A. } \\
\end{array}$ & DURATEX \\
\hline ECORODOVIAS INFRAESTRUTURA E LOGÍSTICA S.A. & ECORODOVIAS \\
\hline $\begin{array}{l}\text { EMBRAER S.A. } \\
\end{array}$ & EMBRAER \\
\hline EDP - ENERGIAS DO BRASIL S.A. & ENERGIAS BR \\
\hline ENEVA S.A & ENEVA \\
\hline EQUATORIAL ENERGIA S.A. & EQUATORIAL \\
\hline ESTACIO PARTICIPACOES S.A. & ESTACIO PART \\
\hline ETERNIT S.A. & ETERNIT \\
\hline EVEN CONSTRUTORA E INCORPORADORA S.A. & EVEN \\
\hline EZ TEC EMPREEND. E PARTICIPACOES S.A. & EZTEC \\
\hline FERTILIZANTES HERINGER S.A. & FER HERINGER \\
\hline FIBRIA CELULOSE S.A. & FIBRIA \\
\hline
\end{tabular}




\begin{tabular}{|c|c|}
\hline FLEURY S.A. & FLEURY \\
\hline GAFISA S.A. & GAFISA \\
\hline GENERAL SHOPPING BRASIL S.A. & GENERALSHOPP \\
\hline GRENDENE S.A. & GRENDENE \\
\hline HELBOR EMPREENDIMENTOS S.A. & $\underline{\text { HELBOR }}$ \\
\hline HYPERMARCAS S.A. & HYPERMARCAS \\
\hline IDEIASNET S.A. & IDEIASNET \\
\hline IGUATEMI EMPRESA DE SHOPPING CENTERS S.A & IGUATEMI \\
\hline INTERNATIONAL MEAL COMPANY ALIMENTACAO S.A. & $\underline{\mathrm{IMC} \mathrm{S} / \mathrm{A}}$ \\
\hline INDUSTRIAS ROMI S.A. & INDS ROMI \\
\hline IOCHPE MAXION S.A. & IOCHP-MAXION \\
\hline JBS S.A. & $\underline{\mathrm{JBS}}$ \\
\hline JHSF PARTICIPACOES S.A. & $\underline{\mathrm{JHSF} \text { PART }}$ \\
\hline JSL S.A. & $\underline{\mathrm{JSL}}$ \\
\hline KROTON EDUCACIONAL S.A. & $\underline{\text { KROTON }}$ \\
\hline RESTOQUE COMÉRCIO E CONFECÇÕES DE ROUPAS S.A. & LE LIS BLANC \\
\hline $\begin{array}{ll}\text { LIGHT S.A. } \\
\end{array}$ & LIGHT S/A \\
\hline LINX S.A. & $\underline{\text { LINX }}$ \\
\hline LOCALIZA RENT A CAR S.A. & LOCALIZA \\
\hline CIA LOCAÇÃO DAS AMÉRICAS & LOCAMERICA \\
\hline LOG-IN LOGISTICA INTERMODAL S.A. & $\underline{\text { LOG-IN }}$ \\
\hline MARISA LOJAS S.A. & LOJAS MARISA \\
\hline LOJAS RENNER S.A. & LOJAS RENNER \\
\hline LPS BRASIL - CONSULTORIA DE IMOVEIS S.A. & LOPES BRASIL \\
\hline LUPATECH S.A. & LUPATECH \\
\hline M.DIAS BRANCO S.A. IND COM DE ALIMENTOS & M.DIASBRANCO \\
\hline MAGAZINE LUIZA S.A. & $\underline{\text { MAGAZ LUIZA }}$ \\
\hline MAGNESITA REFRATARIOS S.A. & MAGNESITA SA \\
\hline MARFRIG GLOBAL FOODS S.A. & MARFRIG \\
\hline MAHLE-METAL LEVE S.A. & METAL LEVE \\
\hline METALFRIO SOLUTIONS S.A. & $\underline{\text { METALFRIO }}$ \\
\hline MILLS ESTRUTURAS E SERVIÇOS DE ENGENHARIA S.A. & MILLS \\
\hline MINERVA S.A. & MINERVA \\
\hline MMX MINERACAO E METALICOS S.A. & MMX MINER \\
\hline MRV ENGENHARIA E PARTICIPACOES S.A. & MRV \\
\hline MULTIPLUS S.A. & $\underline{\text { MULTIPLUS }}$ \\
\hline NATURA COSMETICOS S.A. & NATURA \\
\hline ODONTOPREV S.A. & ODONTOPREV \\
\hline ÓLEO E GÁS PARTICIPAÇÕES S.A. & $\underline{\text { OGX PETROLEO }}$ \\
\hline OSX BRASIL S.A. & OSX BRASIL \\
\hline OURO FINO SAUDE ANIMAL PARTICIPACOES S.A. & OUROFINO S/A \\
\hline PARANAPANEMA S.A. & $\underline{\text { PARANAPANEMA }}$ \\
\hline FPC PAR CORRETORA DE SEGUROS S.A. & PARCORRETORA \\
\hline PDG REALTY S.A. EMPREEND E PARTICIPACOES & PDG REALT \\
\hline PETRO RIO S.A. & $\underline{\text { PETRORIO }}$ \\
\hline PORTO SEGURO S.A. & $\underline{\text { PORTO SEGURO }}$ \\
\hline PORTOBELLO S.A. & PORTOBELLO \\
\hline POSITIVO INFORMATICA S.A. & POSITIVO INF \\
\hline
\end{tabular}




\begin{tabular}{|c|c|}
\hline PROFARMA DISTRIB PROD FARMACEUTICOS S.A. & PROFARMA \\
\hline PRUMO LOGÍSTICA S.A. & $\underline{\text { PRUMO }}$ \\
\hline QGEP PARTICIPAÇÕES S.A. & QGEP PART \\
\hline QUALICORP S.A. & QUALICORP \\
\hline$\underline{\text { RAIA DROGASIL S.A. }}$ & $\underline{\text { RAIADROGASIL }}$ \\
\hline RENAR MACAS S.A. & RENAR \\
\hline RODOBENS NEGOCIOS IMOBILIARIOS S.A. & RODOBENSIMOB \\
\hline ROSSI RESIDENCIAL S.A. & $\underline{\text { ROSSI RESID }}$ \\
\hline RUMO LOGISTICA OPERADORA MULTIMODAL S.A. & $\underline{\text { RUMO LOG }}$ \\
\hline CIA SANEAMENTO BASICO EST SAO PAULO & $\underline{\text { SABESP }}$ \\
\hline SAO CARLOS EMPREEND E PARTICIPACOES S.A. & SAO CARLOS \\
\hline SAO MARTINHO S.A. & $\underline{\text { SAO MARTINHO }}$ \\
\hline SER EDUCACIONAL S.A. & $\underline{\text { SER EDUCA }}$ \\
\hline SONAE SIERRA BRASIL S.A. & SIERRABRASIL \\
\hline SLC AGRICOLA S.A. & $\underline{\text { SLC AGRICOLA }}$ \\
\hline SMILES S.A. & $\underline{\text { SMILES }}$ \\
\hline SOMOS EDUCAÇÃO S.A. & $\underline{\text { SOMOS EDUCA }}$ \\
\hline SPRINGS GLOBAL PARTICIPACOES S.A. & $\underline{\text { SPRINGS }}$ \\
\hline TARPON INVESTIMENTOS S.A. & TARPON INV \\
\hline TECHNOS S.A. & TECHNOS \\
\hline TECNISA S.A. & $\underline{\text { TECNISA }}$ \\
\hline TEGMA GESTAO LOGISTICA S.A. & TEGMA \\
\hline TEMPO PARTICIPACOES S.A. & TEMPO PART \\
\hline TEREOS INTERNACIONAL S.A. & TEREOS \\
\hline TIM PARTICIPACOES S.A. & $\underline{\text { TIM PART S/A }}$ \\
\hline T4F ENTRETENIMENTO S.A. & TIME FOR FUN \\
\hline TOTVS S.A. & $\underline{\text { TOTVS }}$ \\
\hline TRACTEBEL ENERGIA S.A. & TRACTEBEL \\
\hline TRISUL S.A. & TRISUL \\
\hline TPI - TRIUNFO PARTICIP. E INVEST. S.A. & $\underline{\text { TRIUNFO PART }}$ \\
\hline TUPY S.A. & $\underline{\text { TUPY }}$ \\
\hline ULTRAPAR PARTICIPACOES S.A. & ULTRAPAR \\
\hline UNICASA INDÚSTRIA DE MÓVEIS S.A. & $\underline{\text { UNICASA }}$ \\
\hline VANGUARDA AGRO S.A. & $\underline{\text { V-AGRO }}$ \\
\hline VALID SOLUÇÕES E SERV. SEG. MEIOS PAG. IDENT. S.A. & $\underline{\text { VALID }}$ \\
\hline VIGOR ALIMENTOS S.A. & VIGOR FOOD \\
\hline VIVER INCORPORADORA E CONSTRUTORA S.A. & $\underline{\text { VIVER }}$ \\
\hline WEG S.A. & $\underline{\text { WEG }}$ \\
\hline
\end{tabular}

Fonte: BM\&FBovespa

Dessas 131 empresas listadas, apenas 53 têm mais de 50\% de suas ações em circulação no mercado e somente a LUPATECH e a Viver Incorporadora e Construtora têm 100\% de dispersão acionária. 
Figura 2 - Empresas com dispersão Acionária

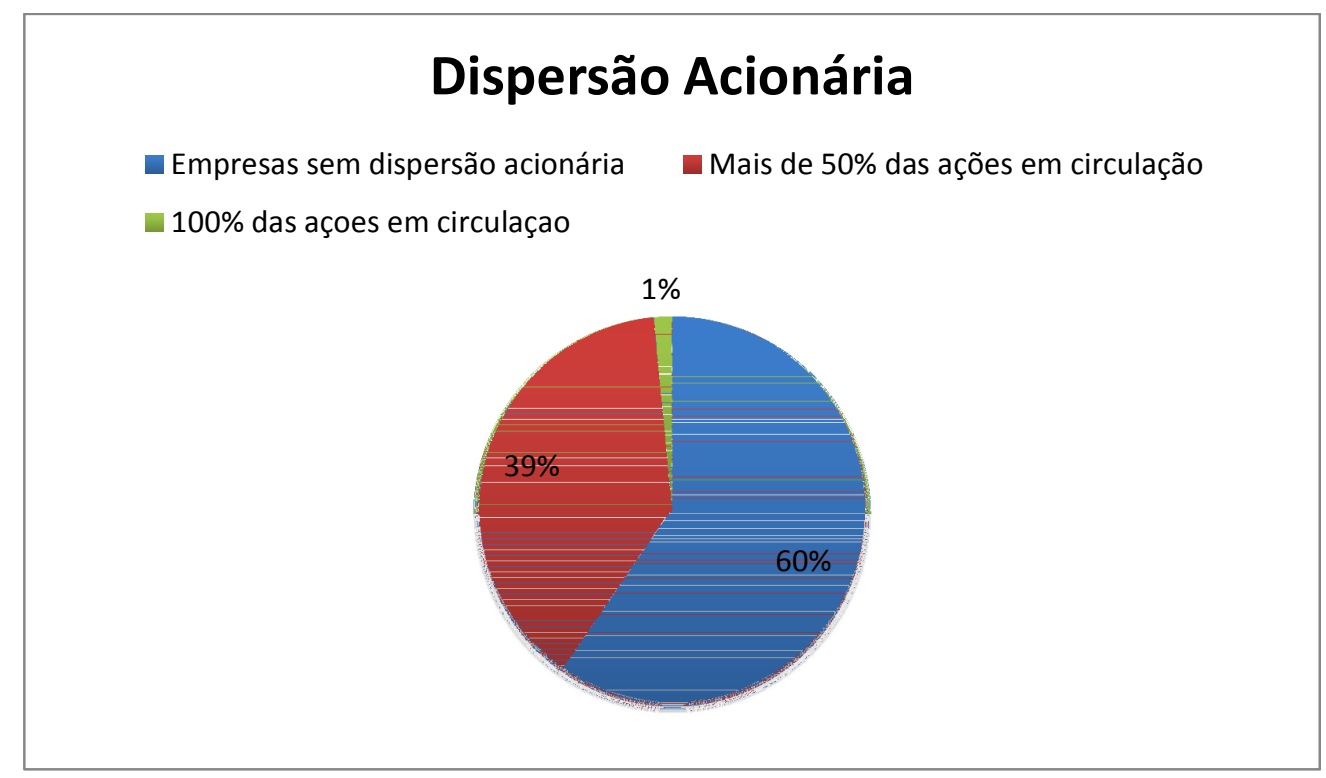

Fonte: BM\&FBovespa

Estes dados mostram com clareza que nossa cultura é de empresas com capital pouco pulverizado e com a concentração das ações na mão de uma pessoa ou um grupo pequeno. 39 empresas listadas no Novo Mercado têm acionista majoritário. Isso demonstra como as empresas ainda concentram seu capital em uma única pessoa. É válido observar também que este dado não inclui as empresas que têm acordo de acionistas o qual também garante uma concentração acionária. Mesmo em empresas com mais de $50 \%$ de suas ações em circulação, temos casos como o da Diagnósticos da América S.A. em que 48,35\% das suas ações estão concentradas em único acionista, um número muito elevado, uma vez que apenas $52,30 \%$ de suas ações se encontram em circulação no mercado.

Em relação à utilização de medidas defensivas contra tomadas hostis de controle, a primeira constatação é que todas as empresas que fazem uso dessa proteção colocam em seu Estatuto Social a medida defensiva estatutária, tornando-se obrigatória a realização de OPA caso um terceiro ou acionista de sua companhia adquira mais do que determinado percentual de suas ações. Segue o exemplo da clausula do estatuto social da Magazine Luiza: "Artigo 41 - Qualquer acionista, que adquira ou torne-se titular de 
ações de emissão da Companhia, em quantidade igual ou superior a $20 \%$ (vinte por cento) deverá, no prazo máximo de 60 (sessenta) dias a contar da data de aquisição ou do evento que resultou na titularidade de ações em quantidade igual ou superior a $20 \%$ (vinte por cento) do total de ações de emissão da Companhia, realizar uma oferta pública de aquisição ("OPA”) da totalidade das ações de emissão da Companhia, observando-se o disposto na regulamentação aplicável da CVM, o Regulamento do Novo Mercado, outros regulamentos da BM\&FBOVESPA e os termos deste artigo. ${ }^{116,}$

70 empresas analisadas apresentam em seu estatuto social a obrigatoriedade de realização de Oferta Pública de Aquisição de Ações e 33 delas não têm seu capital pulverizado na bolsa de valores. Ademais, 14 empresas tem concentração das ações em um único acionista e, mesmo assim, possuem medidas defensivas estatutárias. Por conseguinte, apenas 38 empresas que tem capital pulverizado na bolsa apresentam em seu estatuto medidas defensivas contra tomadas hostis de controle, fato que seria justificável uma vez que estas têm grande dispersão acionária.

Figura 3 - Obrigatoriedade de realização de Oferta Pública de Ações

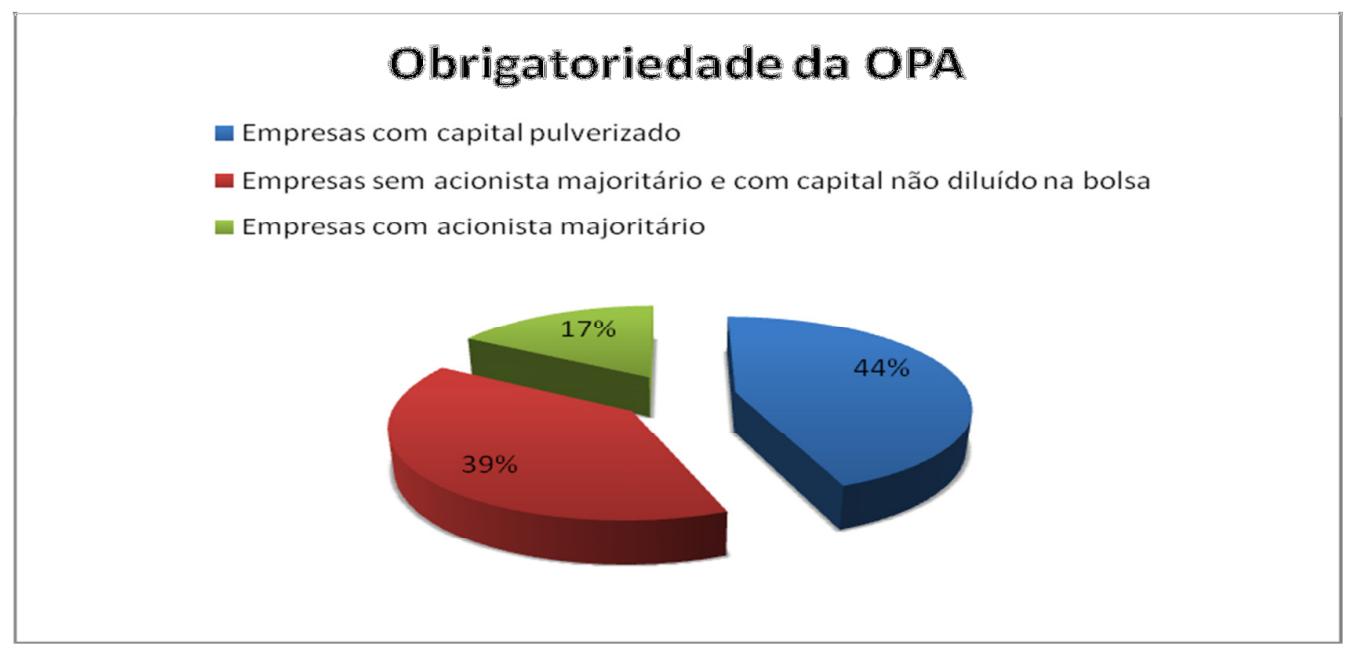

Fonte: BM\&FBovespa

116 Cláusula do Estatuto Social da Magazine Luiza disponível no site da BM\&FBovespa. Disponível em: $<$ http://www.bmfbovespa.com.br/empresas/consbov/ArquivoComCabecalho.asp?motivo=\&protoc olo=487185\&funcao=visualizar\&site $=B>$. Acessado em 29/10/2015. 
Cabe neste ponto ressaltar também o percentual da aquisição de ações que gera a obrigatoriedade de realização da OPA empregado pelas empresas:

Figura 4 - Percentual de ações estipulado nos estatutos sociais das companhias que obrigam o acionista adquirente a realizar a OPA

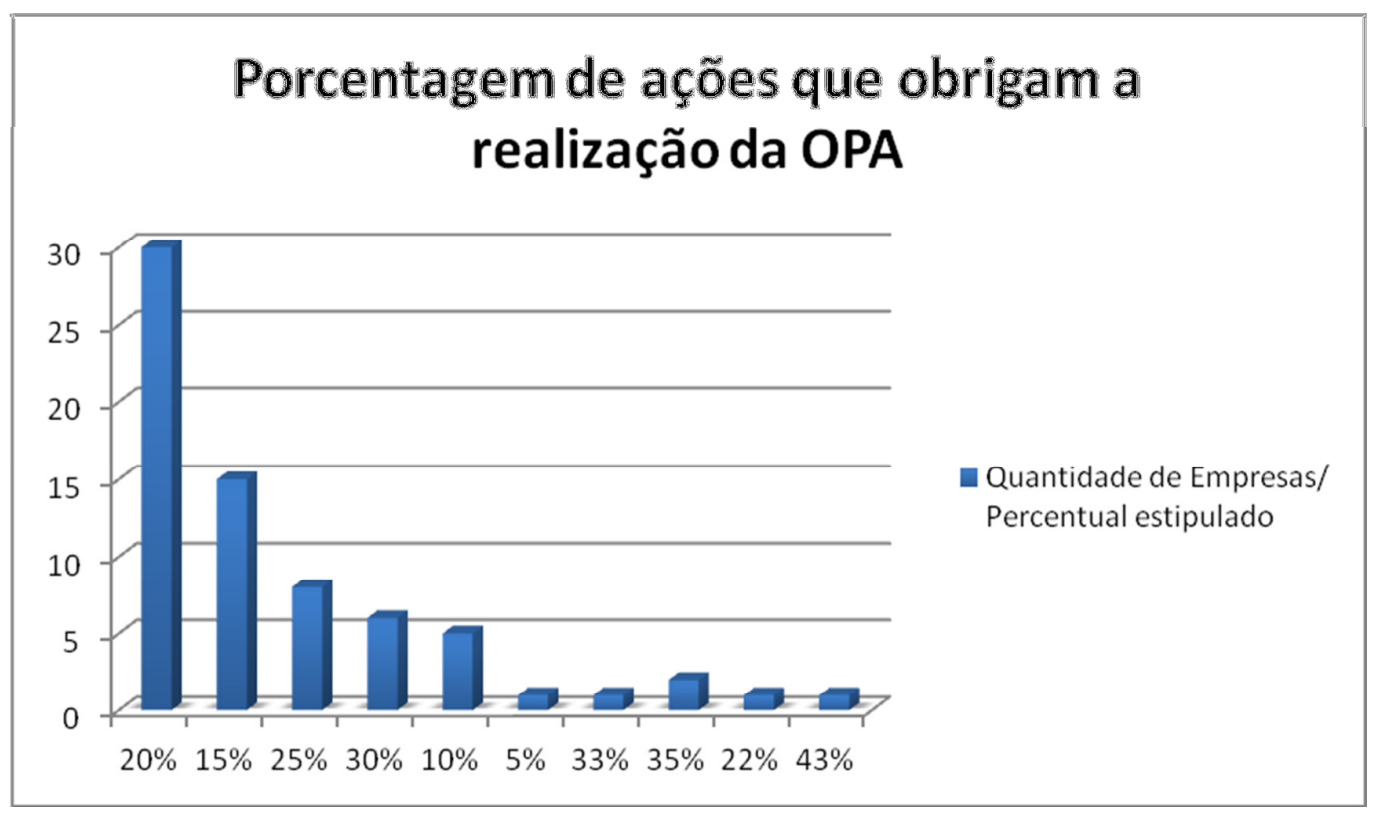

Fonte: BM\&FBovespa

Ultrapassados os dados expostos e as observações, conclui-se que uma quantidade muito pequena de nossas empresas tem seu capital disperso na bolsa. Mesmo assim, muitas empresas com concentração acionária colocam em seus estatutos sociais cláusulas que impedem tomadas e ofertas hostis de controle, casos em que seria impossível essa oferta se concretizar. Isso demonstra que muitas empresas brasileiras usam erroneamente a medida defensiva estatutária e, muitas vezes, perdem oportunidades de investimentos e melhorias apenas para manter o controle estático. 


\section{Conclusão}

Este trabalho teve como objetivo analisar as medidas defensivas contra tomadas hostis de controle e trazer uma perspectiva teórica e prática de sua aplicação no Brasil e nos Estados Unidos.

Primeiro, abordamos o poder de controle e entendemos que acionista controlador é aquele que é titular de direitos de sócio que lhe assegurem de modo permanente e efetivo a maioria dos votos nas deliberações da Assembleia Geral e o poder de eleger a maioria dos administradores, bem como dirigir as atividades da companhia, orientando o funcionamento de seus órgãos e de seus empregados. Constatamos, ainda, que as empresas que tem controle minoritário e gerencial são aquelas suscetíveis às tomadas hostis de controle.

As aquisições de controle podem ser de diversos tipos, como voluntária ou involuntária, mediante uma única operação ou operações sucessivas, e amigável ou hostil. As tomadas hostis de aquisição de controle são peças fundamentais neste trabalho. Concluímos que estas práticas ainda são pouco comuns em nosso ambiente econômico-societário, uma vez que nossas empresas são caracterizadas pela concentração acionária. Contudo, com a criação do segmento do Novo Mercado e da maior confiança dos investidores na economia brasileira, este cenário começou a mudar.

Quando as empresas brasileiras começaram a diluir seu capital, se tornou necessário o uso de medidas defensivas contra terceiros que quisessem adquirir de forma hostil e inesperada o controle de suas companhias.

Ato contínuo, os juristas brasileiros usaram como base as pílulas de veneno amplamente difundidas no direito americano e "abrasileiraram" este instituto. As poison pills criadas no direito americano pelo advogado nova iorquino Martin Lipton não podem ser empregadas em nosso ordenamento

jurídico exatamente como foram originariamente desenhadas. Ao serem 
importadas para o direito brasileiro, estas medidas defensivas acabaram virando sinônimo de medidas protetivas contra tomadas hostis de controle. Isto, nitidamente, demonstra o erro na aplicação desse instituo e a falta, muitas vezes, de um estudo aprofundado sobre o tema, uma vez que, no Brasil, a medida defensiva mais utilizada é a estatutária que estipula a obrigatoriedade de realização de Oferta Pública de Ação.

Não cabe neste trabalho avaliar se as medidas defensivas são ou não benéficas para as empresas, cabe apenas demonstrar seus pontos positivos e negativos e quais tipos poderiam ser empregados no nosso ordenamento jurídico e importadas do direito americano.

A poison pill do tipo flip in, por exemplo, poderia ser usada no Brasil por meio do bônus de subscrição e do plano de opção de compra. Já a medida do flip over não estaria em conformidade com nosso ordenamento. Em relação ao cavaleiro branco e à joia da coroa, estas são legais e foram incorporadas ao nosso direito, sendo que a joia da coroa precisa observar preços de mercado. Além dessas, a defesa do pac man também é aceita no nosso país, uma vez que representa uma oferta originária e estaria submetida à mesma regulação que qualquer outra oferta pública de aquisição de ações. Por fim, o paraquedas dourado é objeto de muita controvérsia entre os doutrinadores e seu uso ainda não foi devidamente regulado.

De todas as medidas, a mais amplamente usada é a medida defensiva estatuária. Conforme vimos nos dados colhidos com as informações da BM\&FBovespa, mais da metade das empresas listadas no segmento do Novo Mercado estipulam em seu estatuto a obrigatoriedade de realização de OPA, sendo que apenas $40 \%$ delas têm mais de $50 \%$ de suas ações em circulação no mercado. Este fato comprova que as empresas brasileiras fazem uso dessas medidas defensivas, mesmo em casos em que não são necessárias, i.e., em casos em que suas ações não correm o risco de serem tomadas por um terceiro estranho ou por um acionista minoritário da companhia. 
Concluo este trabalho, esperando ter fornecido a base necessária à compreensão das medidas defensivas contra tomadas hostis de controle. Espero também ter apresentado o panorama prático de sua aplicação em nosso ordenamento jurídico com dados recentes que podem auxiliar na adoção ou não desses dispositivos nos estatutos sociais das comapnhias abertas. 


\section{Referências Bibliográficas}

BERLE, Adolf A,; MEANS, Gardiner C. The modern corporation and private property. $9^{a}$ edição. New Brunswick/New Jersey: Transaction Publishers, 2007

BULHÕES PEDREIRA, José Luiz. Alienação de Controle de Companhia Aberta. In: LAMY FILHO, Alfredo; BULHÕES PEDREIRA, José Luiz. A Lei das S.A.. v. 2, 2. ed. Rio de Janeiro: Renovar, 1996

CARVAlHOSA, Modesto. Comentários à Lei de Sociedades Anônimas. V.2, 2a ed. São Paulo: Saraiva, 1998

CASTRO, Rodrigo R. Monteiro; ARAGÃO, Leandro Santos de. Direito Societário: Desafios Atuais. São Paulo: Quartier Latin, 2009

CHOPER, Jesse H.; COFFEE Jr. John C.; e GILSON, Ronald J. Cases and materials on corporations. $7^{\mathrm{a}}$ ed. Nova York : Aspen Publishers, 2008

CLARK, Robert Charles. Corporate Law. New York. Aspen Publishers, 1986

COMPARATO, Fábio Konder; SALOMÃOFILHO, Calixto. O poder de controle na Sociedade Anônima. 4ª ed. Rio de Janeiro: Forense, 2005.

CORREA, Cristiane. Sonho Grande. GMT Editores Ltda. 2013

EIZIRIK, Nelson. O mito do "controle gerencial”- alguns dados empíricos. RDM. São Paulo: Malheiros, nº 66, p. 103 - 106, abr./jun., 1987

FRANCO, Vera Helena de Mello. Consideraçoes sobre as ofertas públicas para aquisiçao de açoes (OPAs): estado atual da questão. RDM. São Paulo: Malheiros, $n^{\circ}$ 144, p. 16-58, out./dez. 2006

GARNER, Bryan A. Black's Law Dictionary. $4^{\text {th }}$ Pocket ed. West Group, 2001

GUERREIRO, José Alexandre Tavares. Sociedade anônima: poder e dominação. Revista de Direito Mercantil, Industrial, Econômico e Financeiro. São Paulo, nº 53, janeiro-março/ 1984

LAMY FILHO, Alfredo; BULHÕES PEDREIRA, José Luiz. Direito das Companhias. V.1 e V. 2, Rio de Janeiro: Forense, 2009,

LEITÃO, Luís Manuel Teles de Menezes. As medidas defensivas contra uma oferta pública de aquisiçao hostil. $O$ direito. Ano 138, t.III, Coimbra: Almedina, 2006 
LIPTON, Martin. Pills, polls and professors Redux. The University of Chicago Law Review. Volume 69. Summer 2002. Number 3.

LIPTON, Martin. Takeovers \& Freezeouts. Law Journal Press

LIPTON, Martin; ROWE, Paul K. Pills POlls and Professors. A Reply to Professor Gilson. New York University Center for Law and Business Research Paper, n. 01-006, abr. 2001

LOPEZ, Ernesto Adolfo Hernandez. Bag Wars and Bank Wars, the Gucci and Banque National de Paris Hostile Bids: European Corporate Culture Responds to active Shareholders. Fordham Journal of Corporate \& Financial Law. v.9, $\mathrm{n}^{\circ} 1$

MACEDO, Ricardo Ferreira de. Controle não societário. Rio de Janeiro: Renovar, 2004

MITCHELL, Mark L.; MULHERIN, J. Harold. The impact of Industry shocks on Takeover and Restructuring Activity. Journal of Financial Economisc. V.41, 1996

MORAES, Luiza Rangel de. A pulverização do Controle de Companhias Abertas. RDB. São Paulo: RT, no 32, p. 49-84, abr./jun. 2006

MUNHOZ, Eduardo Secchi. Desafios do direito societário brasileiro na disciplina da companhia aberta: avaliação dos sistemas de controle diluído e concentrado

MUSSNICH, Francisco Antunes Maciel. Análise prática e consideraçoes sobre a relaidade e a aplicaçao das medidas de protectao à tomada hostil de controle nos estatutos sociais das comapnhias abertas brasileiras (Brazilian pills). In: SILVA, Alexandre Coutro. Direito Societário, Estudos sobre a lei de sociedades por açoes. Editora Saraiva, 2013

NASCIMENTO, João Pedro Barroso do. Medidas defensivas à Tomada de Controle de Companhias. Editora Quartier Latin do Brasil. 2011

PASTERIS, Carlo. Il Controllo. Milão. Giuffrè, 1957

REQUIÃO, Rubens. Curso de direito comercial. V.2, $20^{\circ}$ ed. São Paulo: Saraiva, 1995

SALOMÃO FILHO, Calixto. O novo direito societário. $3^{\mathrm{a}}$ ed. São Paulo: Malheiros, 2006

SUBRAMANIAN, Guhan. The Poison Pill. Harvard Business School Review, Cambridge, 9 Nov. 2001, p. 1

VALADARES, Silvia Mourthé; LEAL, Ricardo Pereira Câmara. Ownership and Control Structure of Brazilian Companies. 2000. 
Disponível

em

SSR:

$<$ http://papers.ssrn.com/sol3/papers.cfm?abstract_id=213409 $>$. Acessado em 24/09/2015.

VELASCO, Julian. Justo do it: an antidote to the Poison Pill. Emory Law Journal, n. 52, jul. 2003 


\section{Anexo 1}

\begin{tabular}{|c|c|c|c|c|c|c|}
\hline Razão Social & $\begin{array}{c}\text { Nome do } \\
\text { Pregão }\end{array}$ & Ações ON & $\begin{array}{c}\text { Ações em } \\
\text { Circulação }\end{array}$ & $\begin{array}{c}\text { Porcentagem } \\
\text { de ações em } \\
\text { circulação }\end{array}$ & $\begin{array}{c}\text { Medidas } \\
\text { Defensivas }\end{array}$ & $\begin{array}{c}\text { Acionista com maior } \\
\text { participação acionária }\end{array}$ \\
\hline \begin{tabular}{c} 
ALIANSCE SHOPPING \\
\hline CENTERS S.A.
\end{tabular} & ALIANSCE & 162.735 .921 & $\underline{79.678 .412}$ & $48,96 \%$ & OPA: $43 \%$ & $\begin{array}{c}\text { Canada Pension Plan } \\
\text { Investment Board: } 29,16 \%\end{array}$ \\
\hline GAEC EDUCAÇ̃̃O S.A. & ANIMA & 82.866 .371 & $\underline{36.571 .481}$ & $44.13 \%$ & OPA: $20 \%$ & $\begin{array}{c}\text { Daniel Faccini Castanho: } \\
15,25 \%\end{array}$ \\
\hline
\end{tabular}




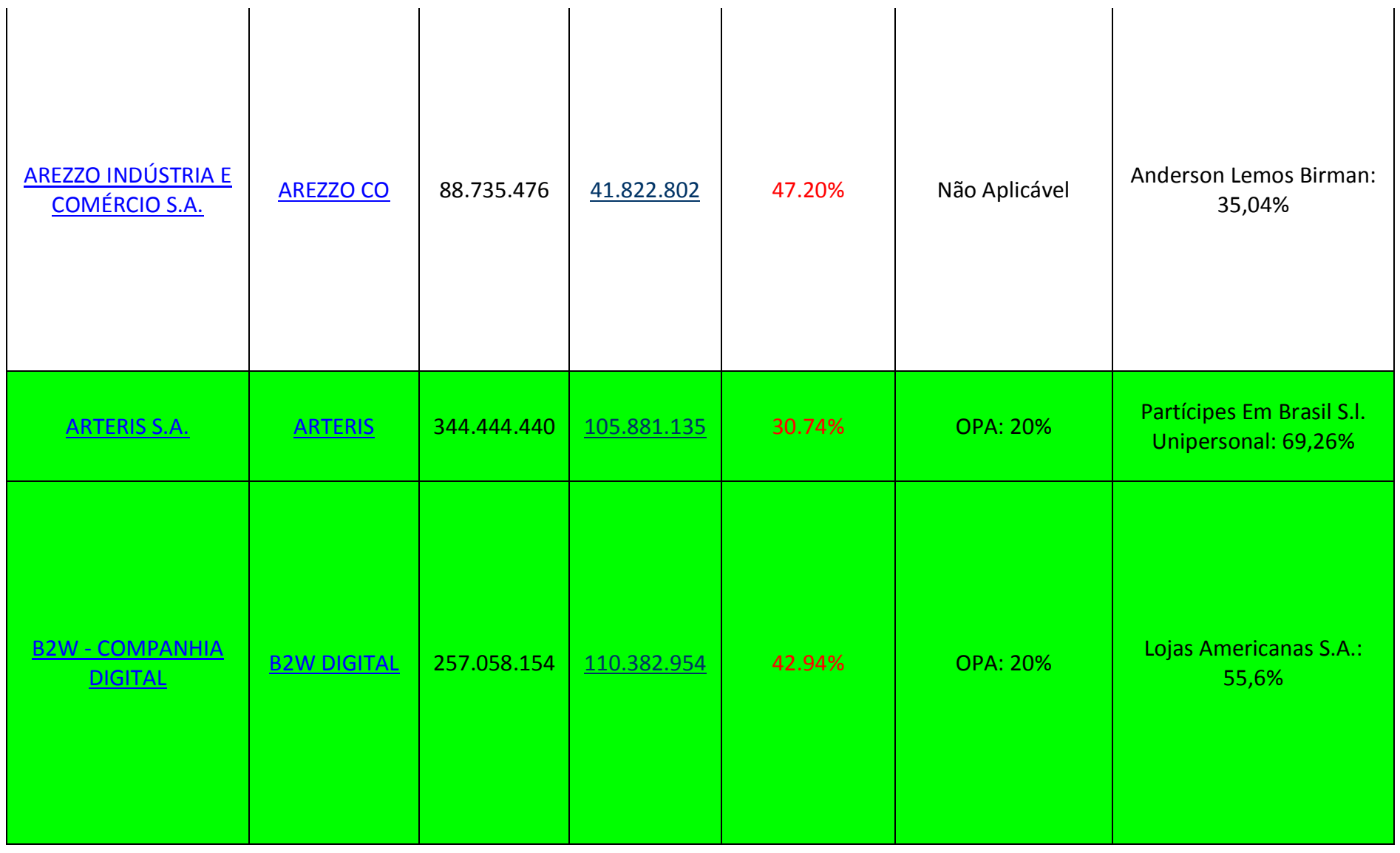




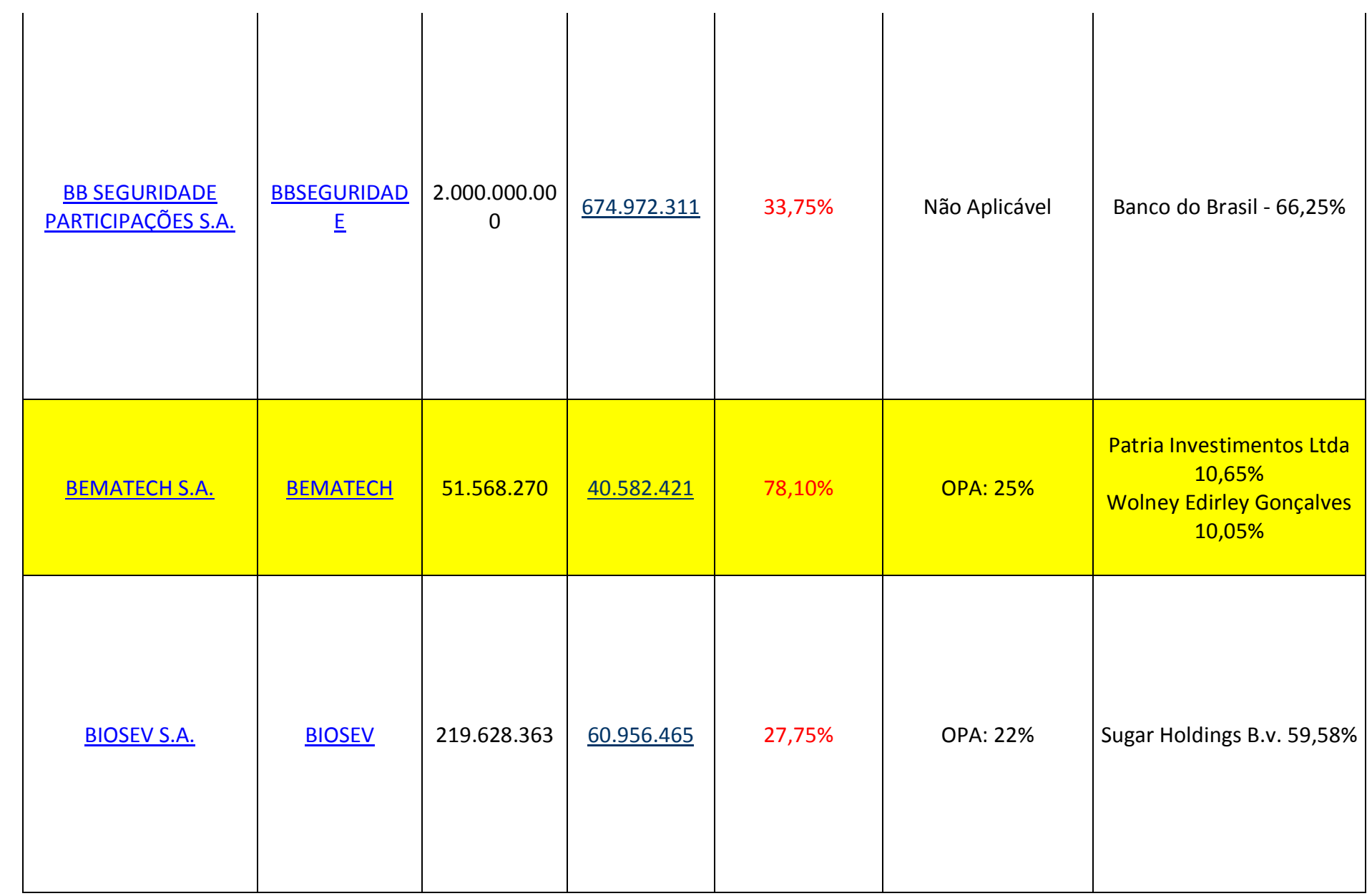




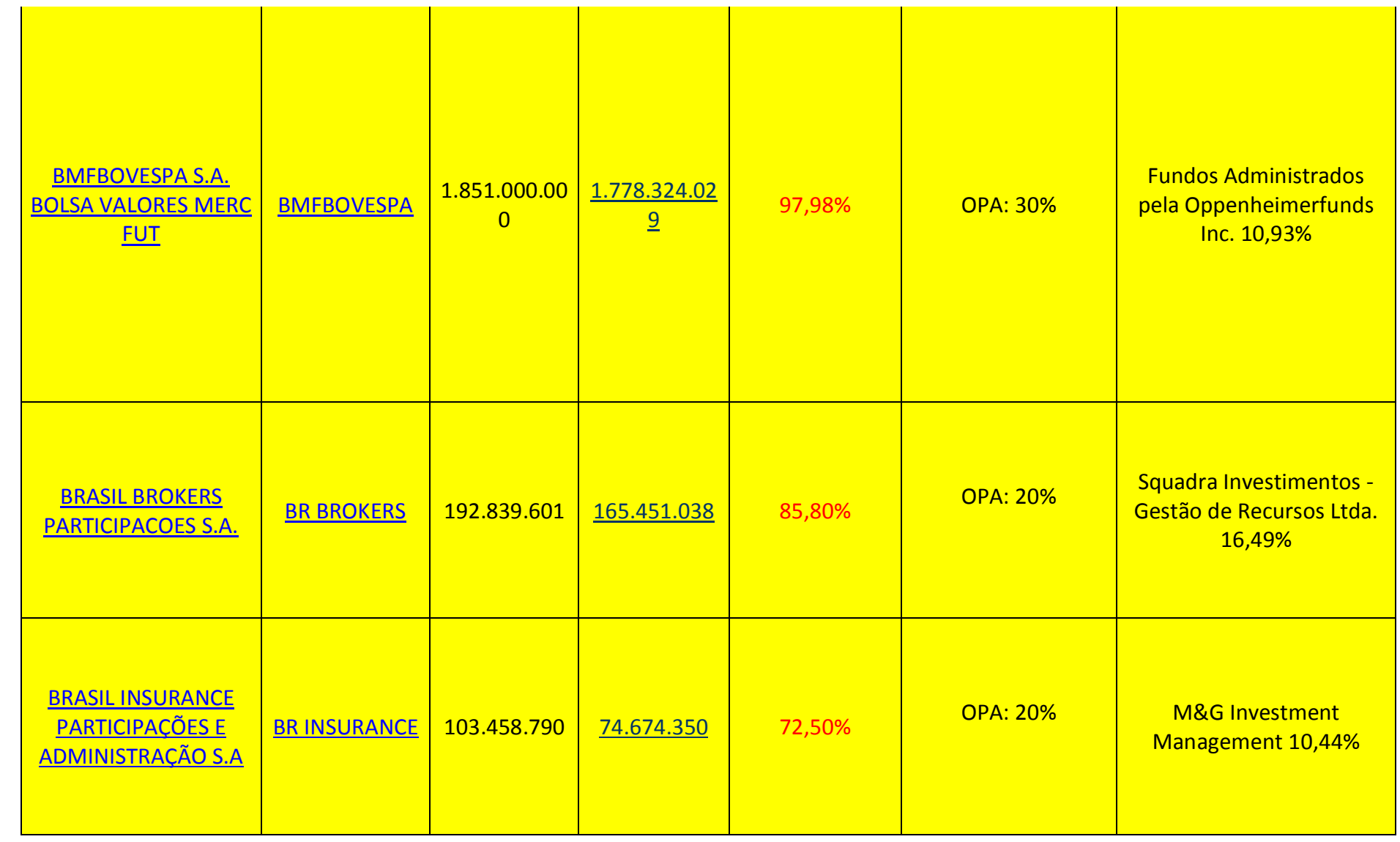




\begin{tabular}{|c|c|c|c|c|c|c|}
\hline $\begin{array}{c}\text { BR MALLS } \\
\text { PARTICIPACOES S.A. }\end{array}$ & BR MALLS PAR & 463.712 .961 & 462.652 .489 & $99,80 \%$ & OPA: $20 \%$ & $\begin{array}{l}\text { Dispersão Acionária: } \\
\text { Dodge \& Cox-13,80\% }\end{array}$ \\
\hline BRASIL PHARMA S.A. & BR PHARMA & 363.051 .086 & 362.180 .947 & $99,76 \%$ & OPA: $30 \%$ & $\begin{array}{c}\text { Dispersão Acionária: } \\
\text { BTG Alpha Investments LLc } \\
15,24 \% \\
\text { Btg Pactual Stigma LLc } \\
14,25 \%\end{array}$ \\
\hline BR PROPERTIES S.A. & BR PROPERT & 298.228 .434 & $\underline{295.259 .171}$ & $99,00 \%$ & $\begin{array}{c}\text { OPA: } 20 \% \\
\text { Preço a ser ofertado } \\
\text { pelasn ações de } \\
\text { emissão da } \\
\text { Companhia objeto } \\
\text { da OPA deverá ser o } \\
\text { preço justo, } \\
\text { entendido como } \\
\text { sendo ao menos } \\
\text { igual ao }\end{array}$ & $\begin{array}{l}\text { Propertyco Fundo de } \\
\text { Investimento } \\
\text { Multimercado Crédito } \\
\text { Privado - Investimento no } \\
\text { Exterior (fimm): } 19,55 \%\end{array}$ \\
\hline BCO BRASIL S.A. & BRASIL & $\begin{array}{c}2.865 .417 .02 \\
0\end{array}$ & 839.653 .556 & $29,30 \%$ & Não Aplicável & $\begin{array}{l}\text { Secretaria do Tesouro } \\
\text { Nacional: } 50,73 \%\end{array}$ \\
\hline
\end{tabular}




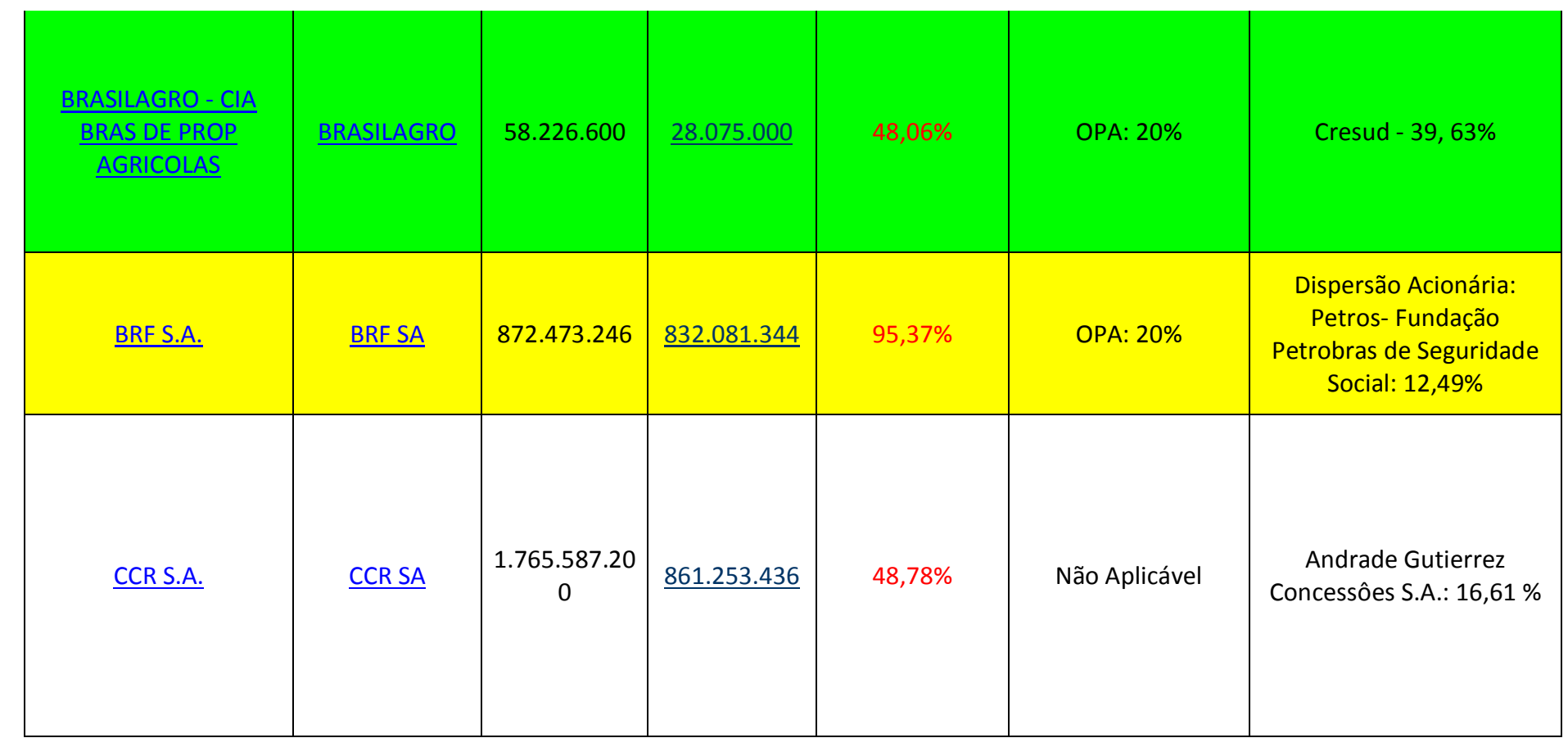




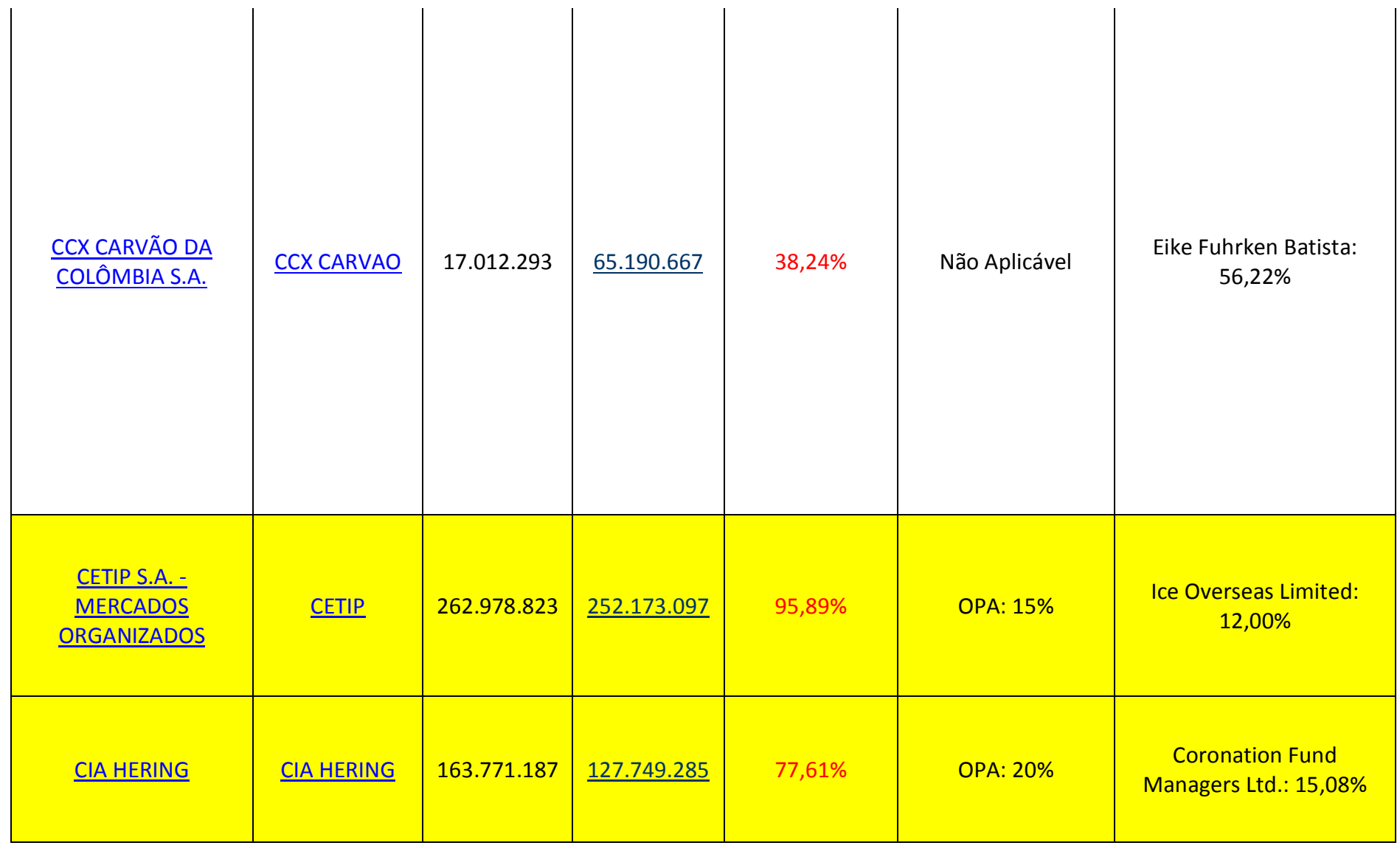




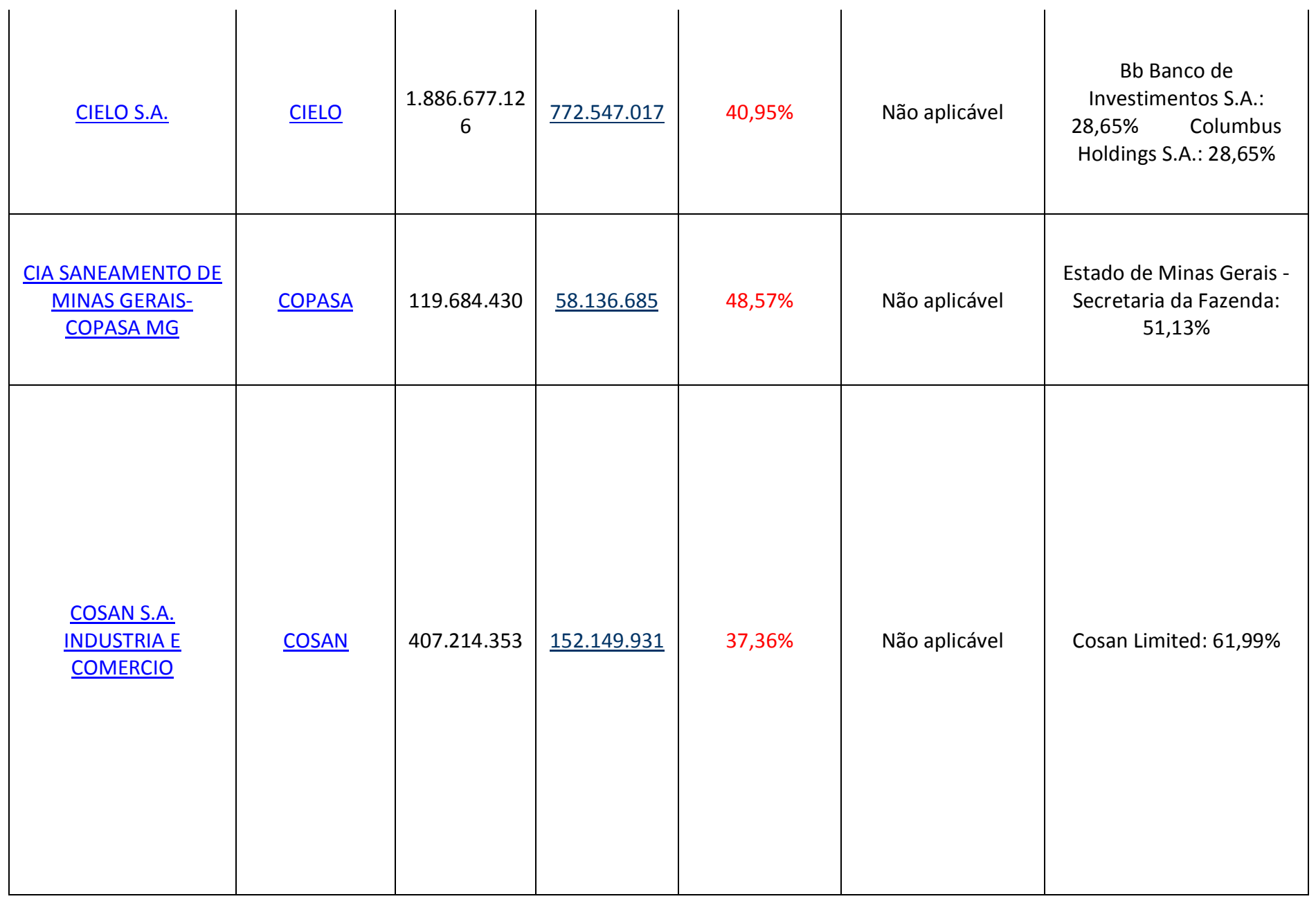




\begin{tabular}{|c|c|c|c|c|c|c|}
\hline COSAN LOGISTICA S.A. & COSAN LOG & 405.856 .814 & $\underline{151.098 .726}$ & $37,23 \%$ & Não Aplicável & Cosan Limited: 62,20\% \\
\hline CPFL ENERGIA S.A. & CPFL ENERGIA & 993.014.215 & 308.487 .239 & $31,07 \%$ & Não Aplicável & $\begin{array}{c}\text { Fundo Mútuo de } \\
\text { Investimentos em Ações - } \\
\text { Bb Carteira Livre I: } 26,45 \% \\
\text { Esc Energia S.A.: } 23,57 \%\end{array}$ \\
\hline $\begin{array}{l}\text { CPFL ENERGIAS } \\
\text { RENOVÁVEIS S.A. }\end{array}$ & CPFL RENOVAV & 503.308.389 & $\underline{211.585 .170}$ & $38,85 \%$ & Não Aplicável & $\begin{array}{l}\text { Cpfl Geração de Energia } \\
\text { S.A.: } 51,61 \%\end{array}$ \\
\hline $\begin{array}{c}\frac{\text { CR2 }}{\text { EMPREENDIMENTOS }} \\
\text { IMOBILIARIOS S.A. }\end{array}$ & $\underline{\mathrm{CR} 2}$ & 48.443 .062 & 37.220 .240 & $76,83 \%$ & Não Aplicável & $\begin{array}{c}\text { Itau Unibanco S.A.: } 19,64 \% \\
\text { Squadra Investimentos } \\
\text { Gestão de Recursos Ltda.: } \\
19,63 \%\end{array}$ \\
\hline
\end{tabular}



Ltd.: $43,91 \%$ 


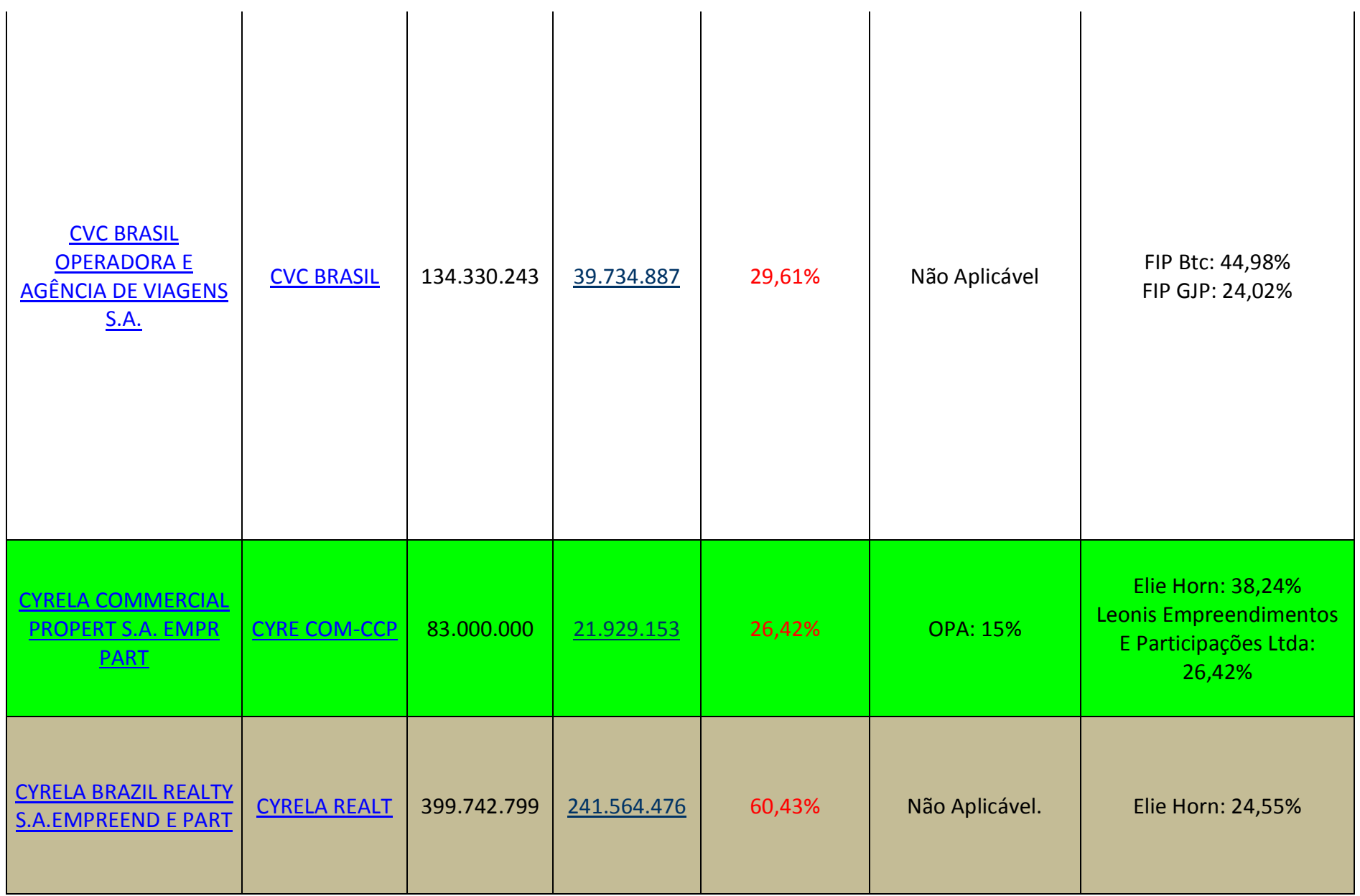




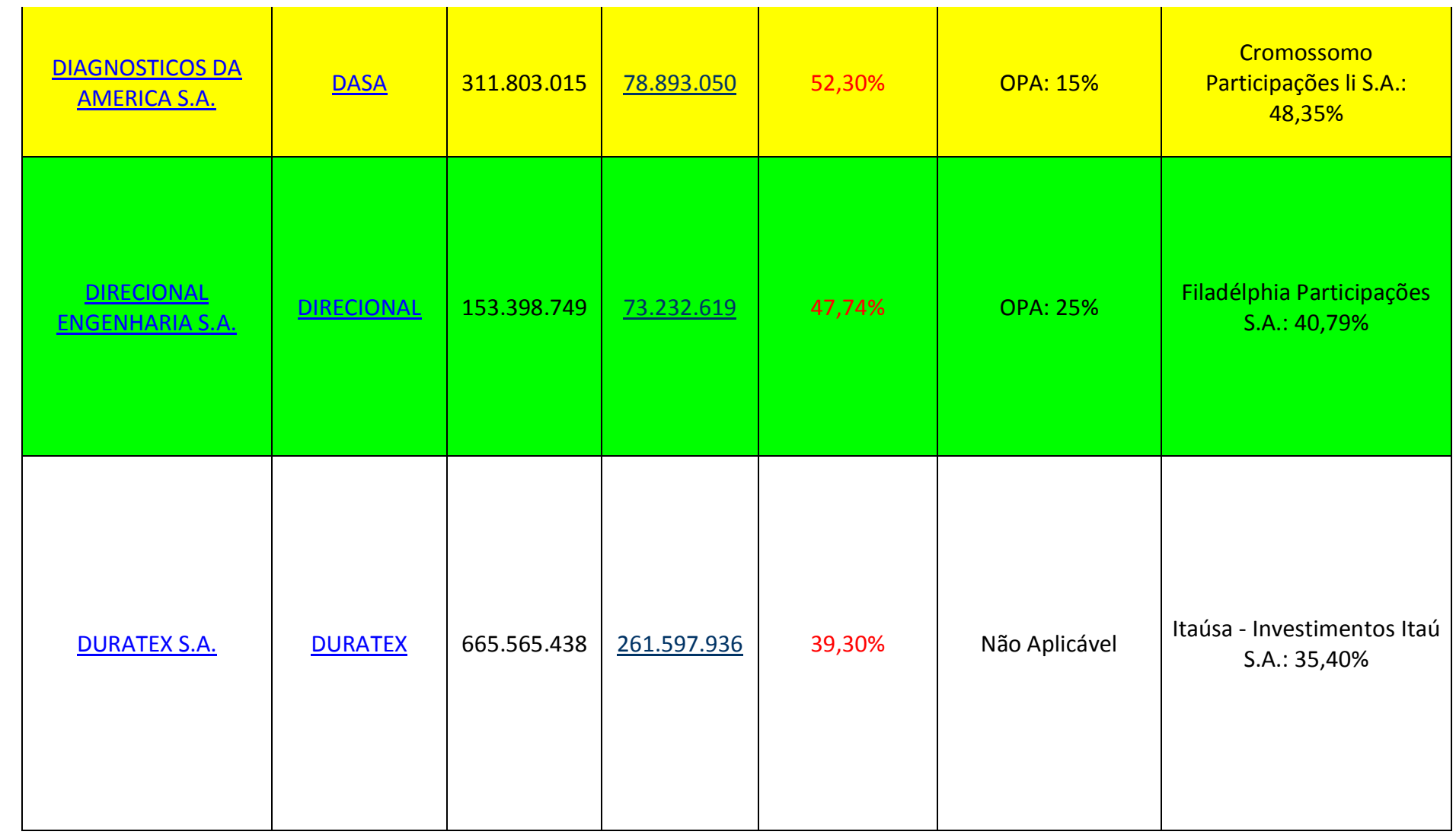




\begin{tabular}{|c|c|c|c|c|c|c|}
\hline $\begin{array}{l}\frac{\text { ECORODOVIAS }}{\text { INFRAESTRUTURA E }} \\
\underline{\text { LOGÍSTICA S.A. }}\end{array}$ & ECORODOVIAS & 558.699 .080 & $\underline{198.834 .559}$ & $35,59 \%$ & Não Aplicável & $\begin{array}{l}\text { Primav Construções e } \\
\text { Comércio S.A.: } 63,99 \%\end{array}$ \\
\hline EMBRAER S.A. & EMBRAER & 740.465 .044 & $\underline{736.053 .091}$ & $99,40 \%$ & OPA: $35 \%$ & $\begin{array}{c}\text { Oppenheimer Funds: } \\
13,36 \%\end{array}$ \\
\hline$\frac{\text { EDP - ENERGIAS DO }}{\text { BRASIL S.A. }}$ & ENERGIAS BR & 476.415 .612 & 232.602 .876 & $48,82 \%$ & Não Aplicável & $\begin{array}{l}\text { Energias de Portugal } \\
\text { Investments and Services } \\
\text { Sociedad Ltda.: } 35,30 \%\end{array}$ \\
\hline ENEVA S.A & ENEVA & 840.106 .107 & 311.198.872 & $37,04 \%$ & Não Aplicável & $\begin{array}{l}\text { Dd Brazil Holdings S.á.r.l: } \\
42,94 \%\end{array}$ \\
\hline
\end{tabular}




\begin{tabular}{|c|c|c|c|c|c|c|}
\hline \begin{tabular}{c|c|c|c|} 
EQUATORIAL ENERGIA \\
\hline$\underline{\text { S.A. }}$
\end{tabular} & EQUATORIAL & 198.551 .102 & $\underline{197.784 .403}$ & $99,66 \%$ & Não Aplicável. & $\begin{array}{c}\text { Squadra Investimentos } \\
\text { Gestão de Recursos Ltda.: } \\
15,70 \%\end{array}$ \\
\hline $\begin{array}{c}\text { ESTACIO } \\
\text { PARTICIPACOES S.A. }\end{array}$ & ESTACIO PART & 316.684 .999 & $\underline{296.026 .552}$ & $84,95 \%$ & OPA: $20 \%$ & $\begin{array}{c}\text { Oppenheimer Funds: } \\
17,10 \%\end{array}$ \\
& & & & & & \\
\end{tabular}




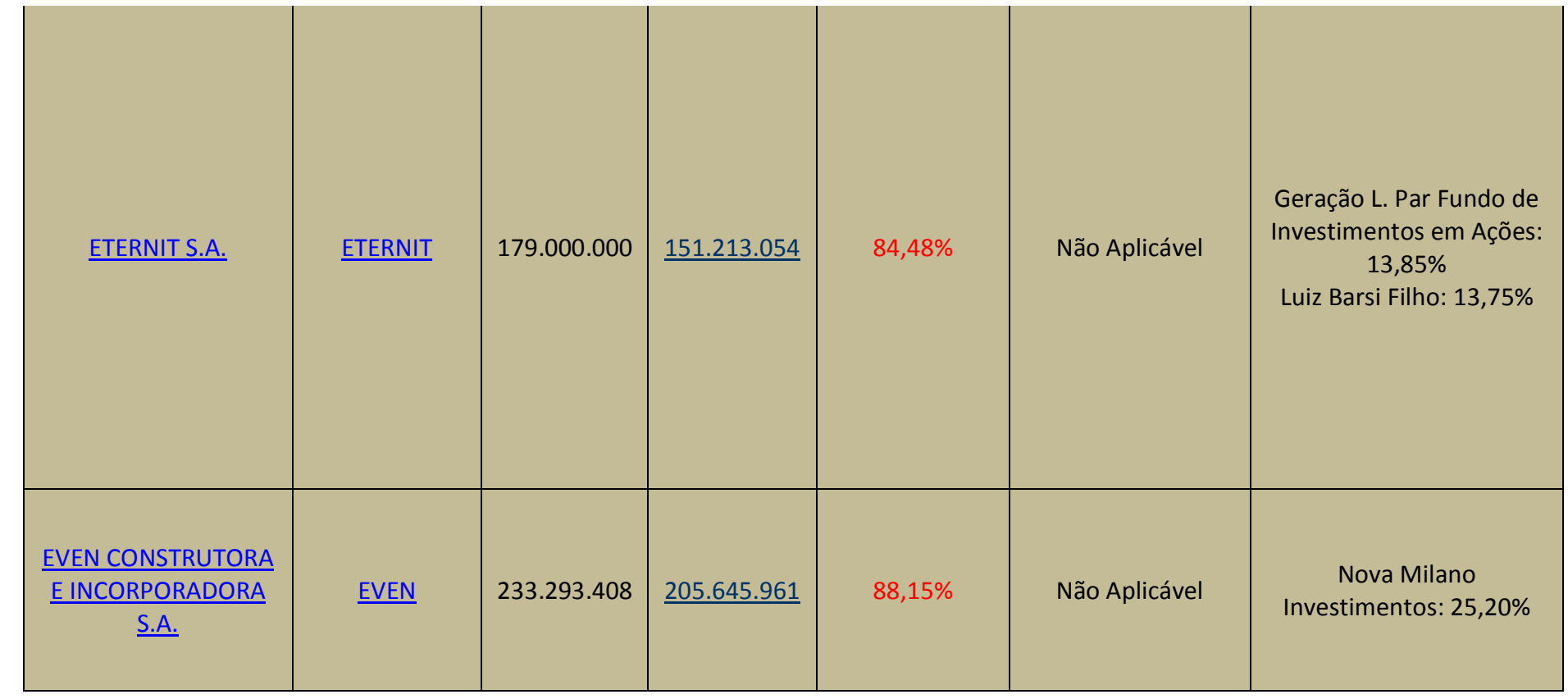




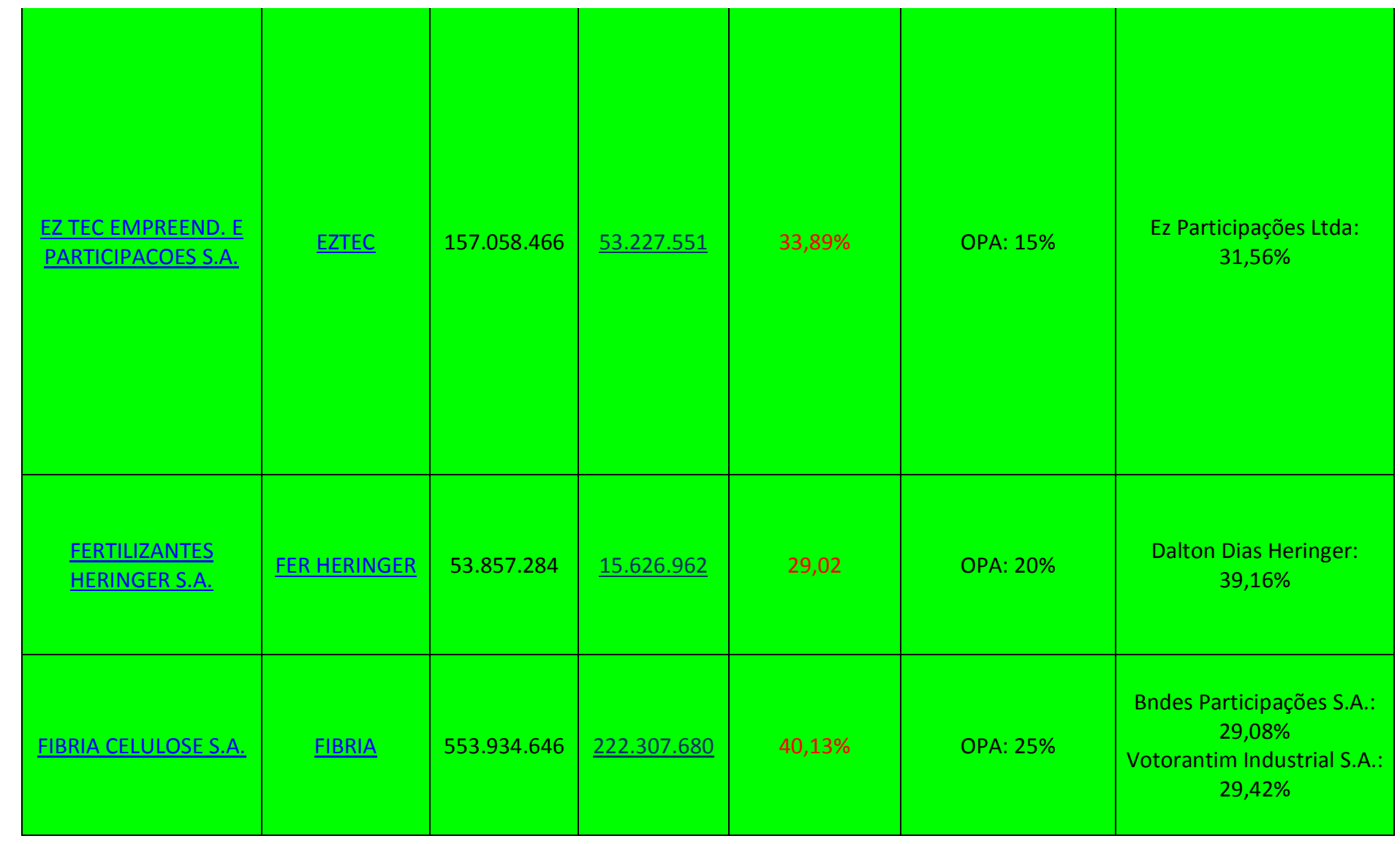




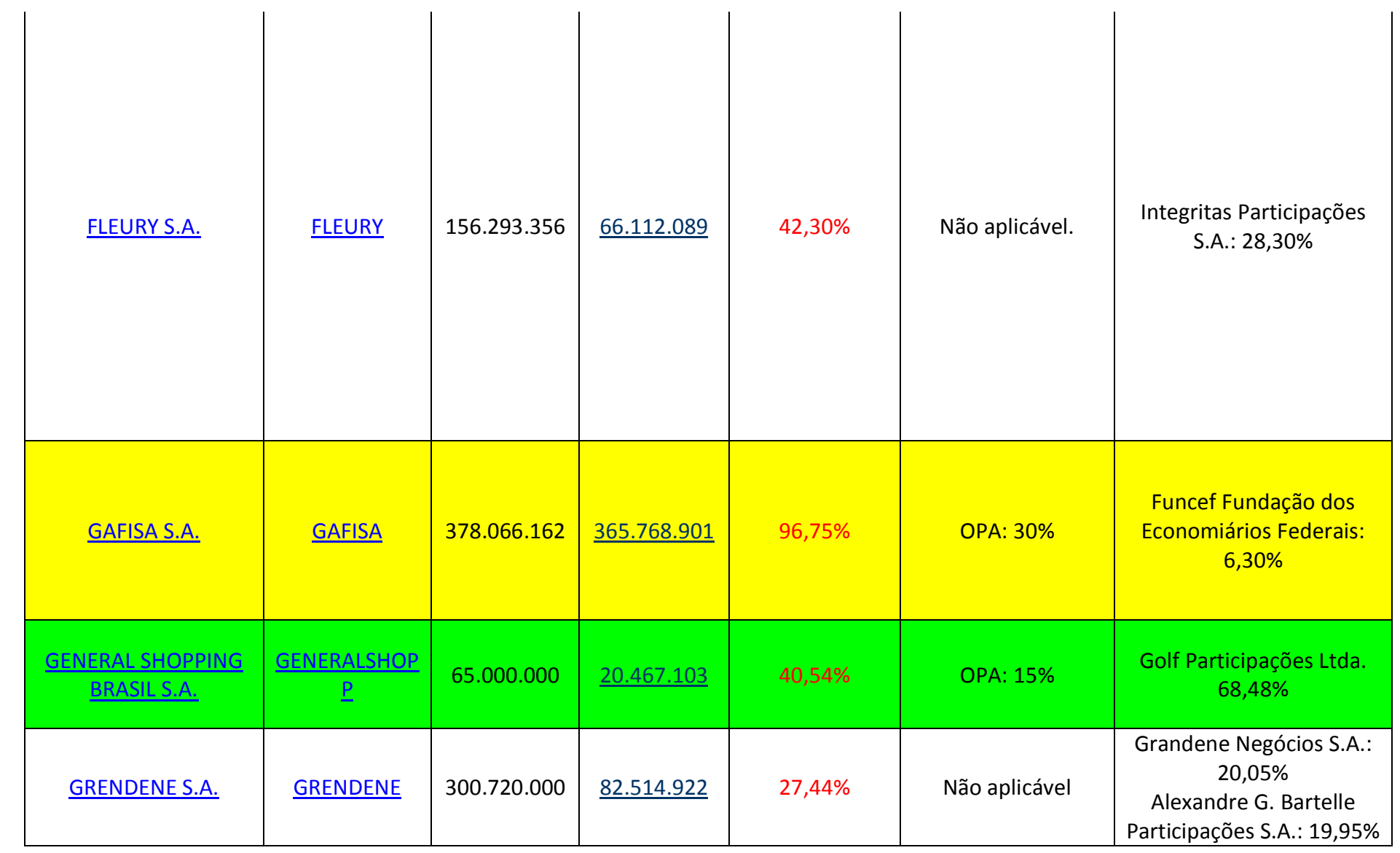




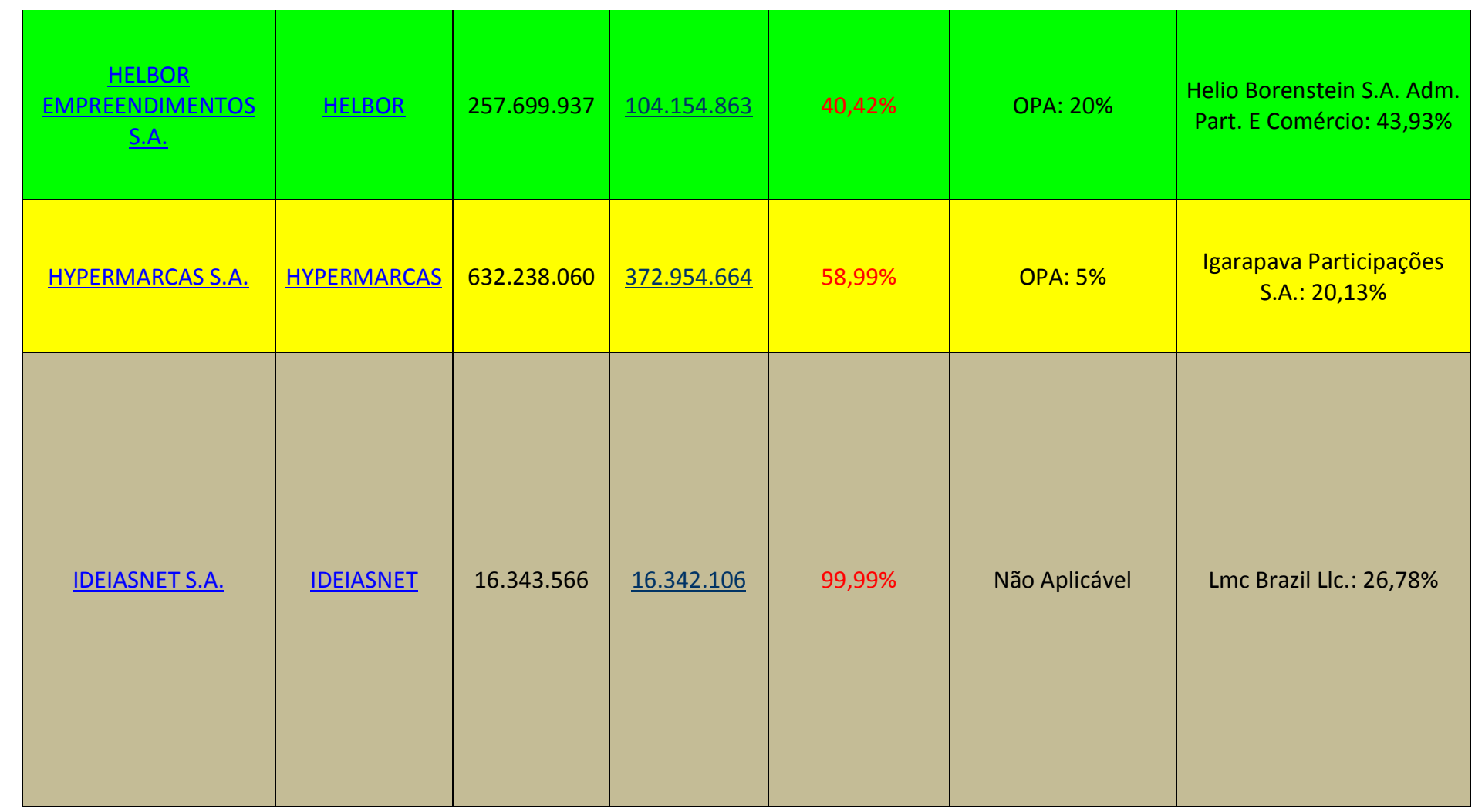




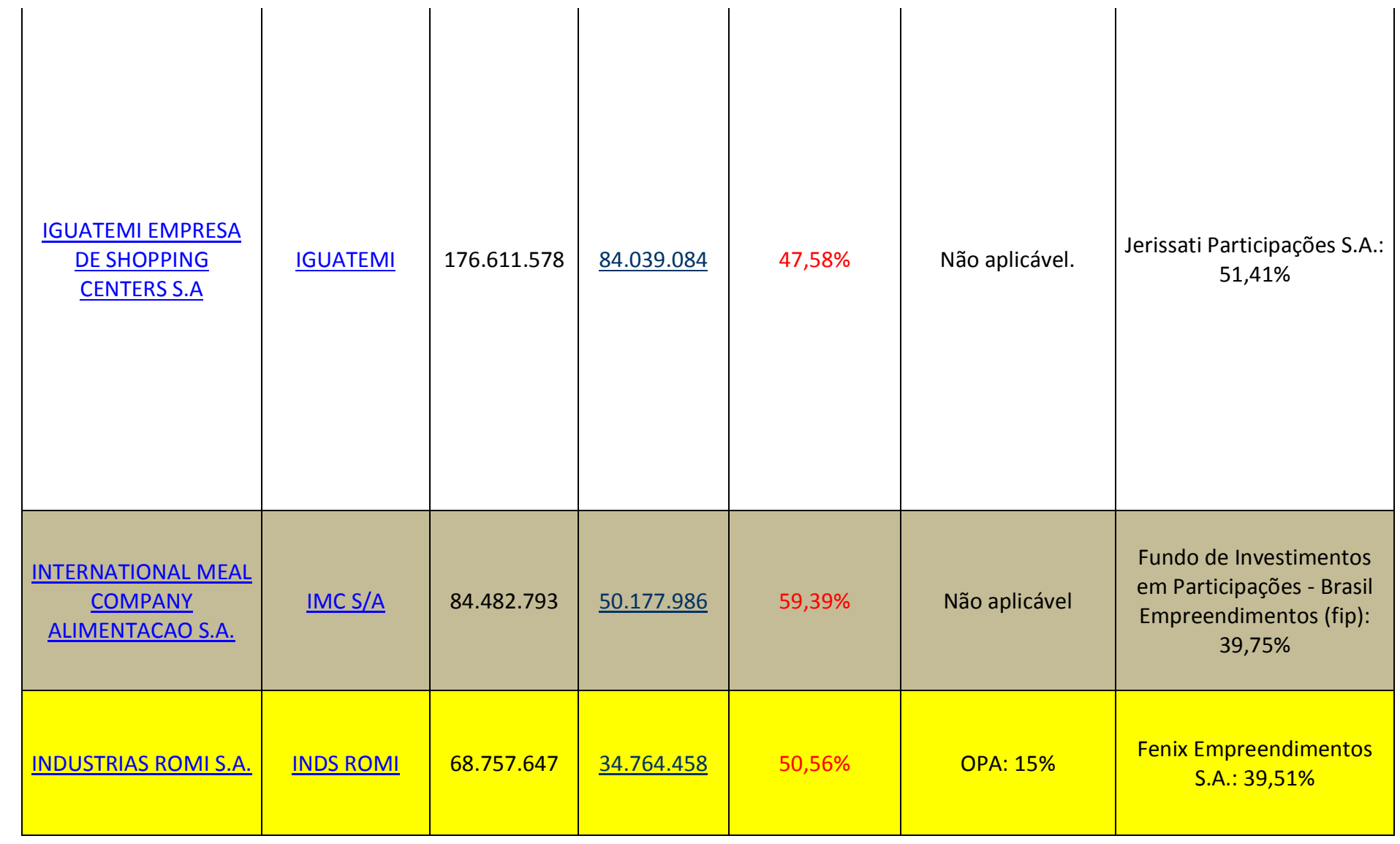




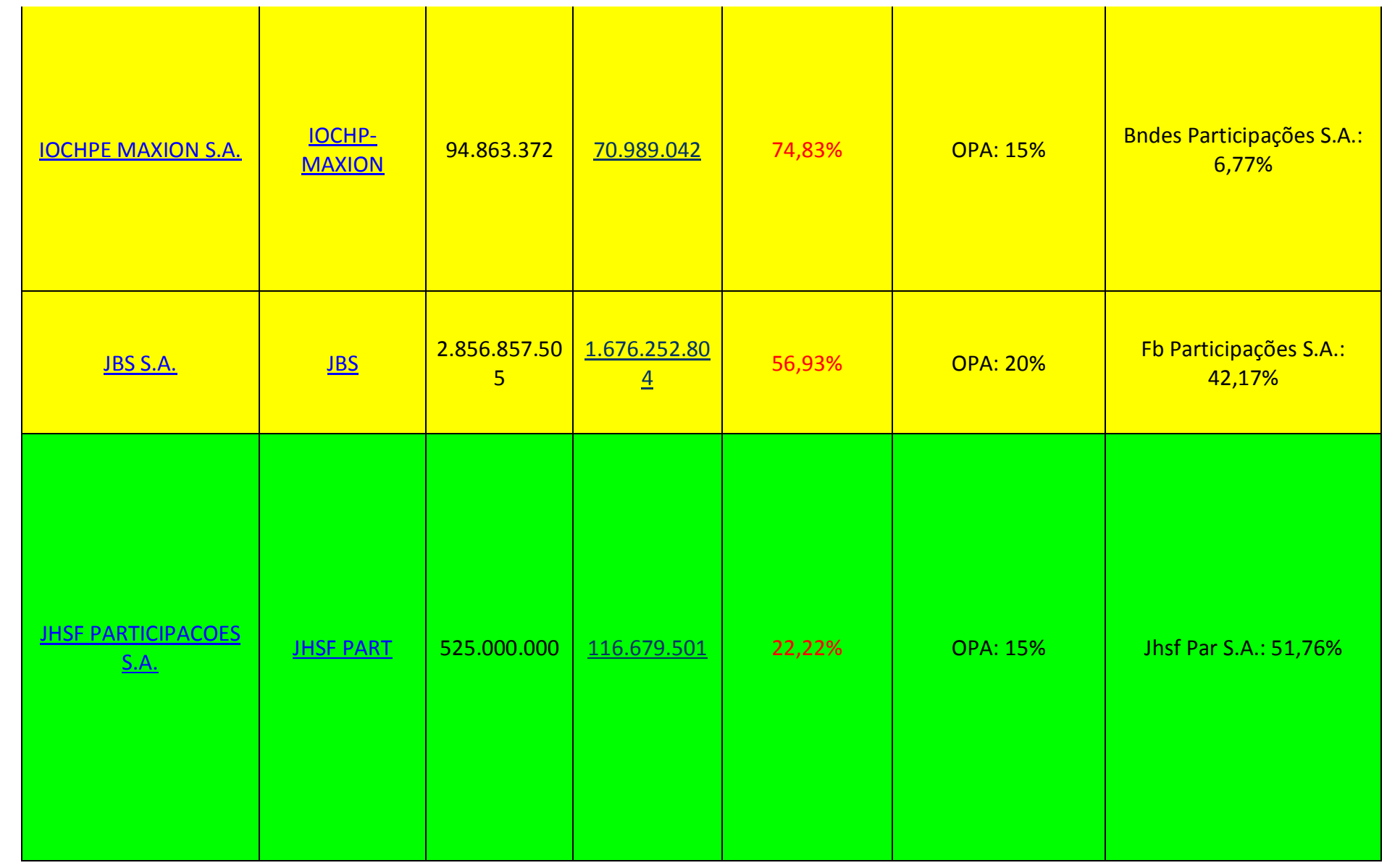




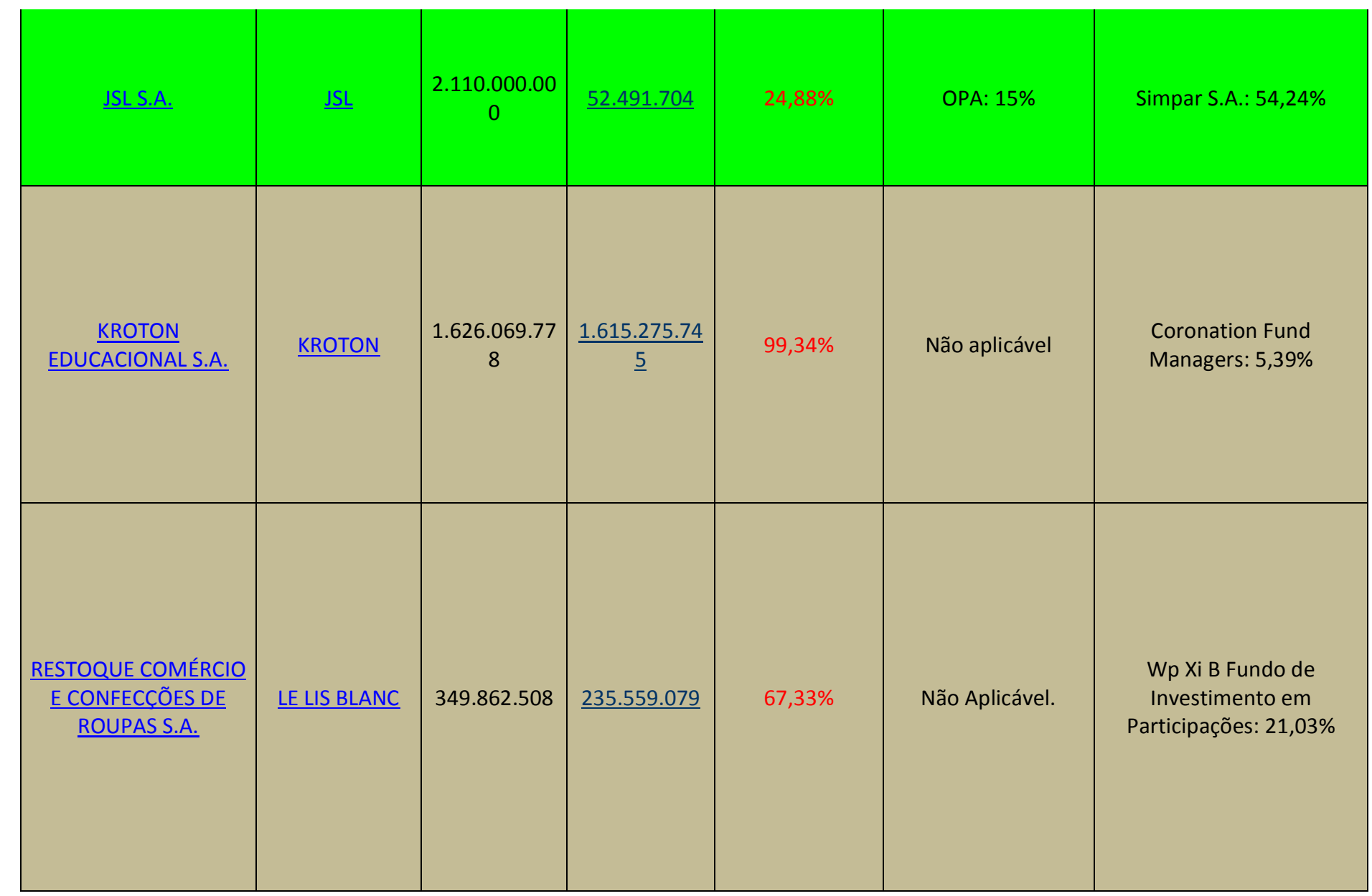




\begin{tabular}{|c|c|c|c|c|c|c|}
\hline LIGHT S.A. & LIGHT S/A & 203.934 .060 & $\underline{97.629 .475}$ & $47,87 \%$ & Não Aplicável & $\begin{array}{c}\text { Companhia Energética de } \\
\text { Minas Gerais (Cemig): } \\
26,06 \%\end{array}$ \\
\hline LINX S.A. & $\underline{\text { LINX}}$ & 46.836 .541 & $\underline{32.932 .383}$ & $70,41 \%$ & OPA: $25 \%$ & $\begin{array}{l}\text { Nércio José Monteiro } \\
\text { Fernandes: } 10,86 \%\end{array}$ \\
\hline$\frac{\text { LOCALIZA RENT A CAR }}{\text { S.A. }}$ & LOCALIZA & 211.793 .400 & $\underline{149.615 .920}$ & $70,64 \%$ & OPA: $15 \%$ & $\begin{array}{l}\text { Lazard Asset Management } \\
\text { Securities Llc: } 12,53 \%\end{array}$ \\
\hline$\frac{\text { CIA LOCAČÃO DAS }}{\underline{\text { AMÉRICAS }}}$ & LOCAMERICA & 65.075 .322 & $\underline{33.096 .180}$ & $50,86 \%$ & OPA: $25 \%$ & $\begin{array}{c}\text { Luis Fernando Memoria } \\
\text { Porto: } 23,50 \% \\
\text { Sergio Augusto Guerra de } \\
\text { Resende: } 23,50 \% \\
\text { Patria Investimentos Ltda: } \\
18,02 \%\end{array}$ \\
\hline
\end{tabular}




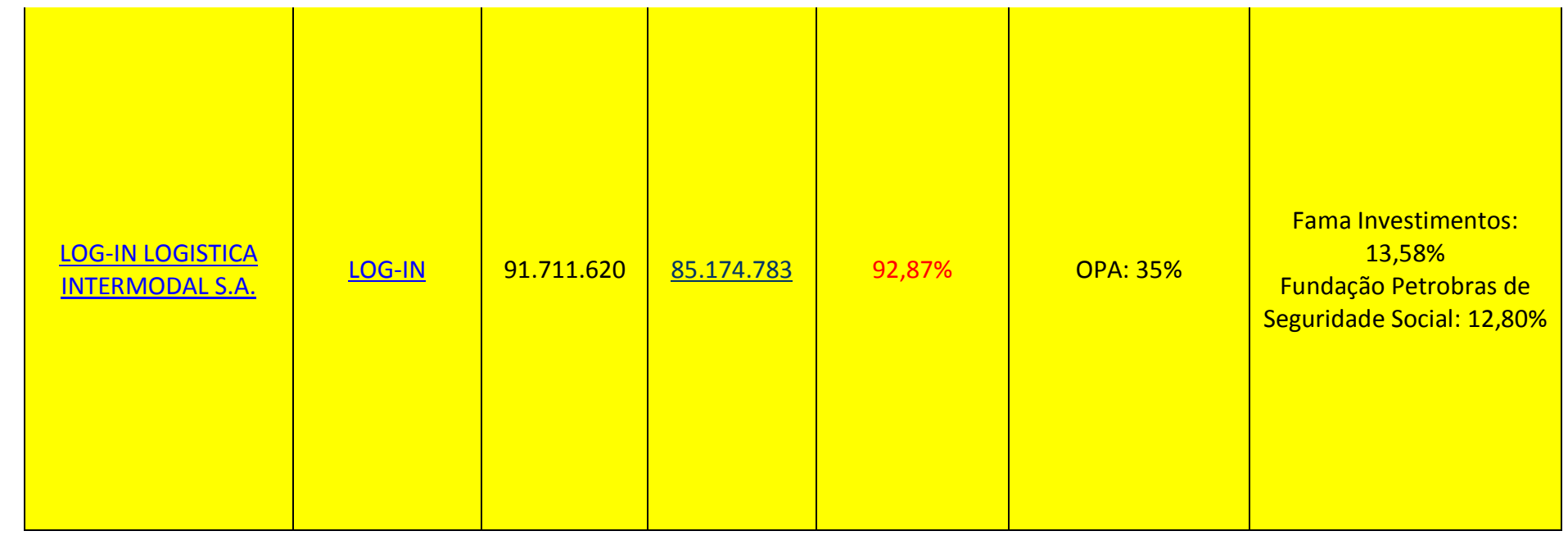




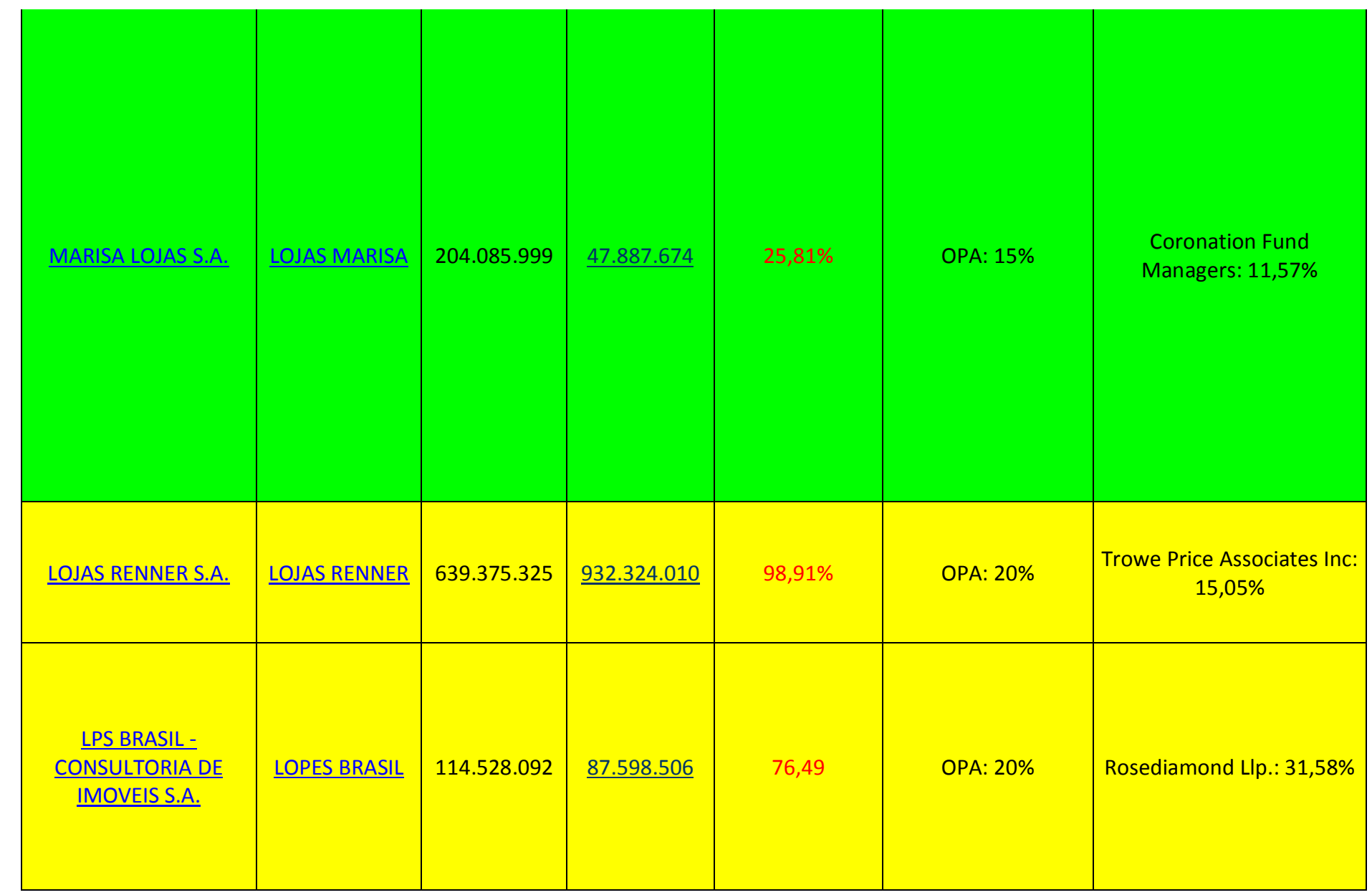




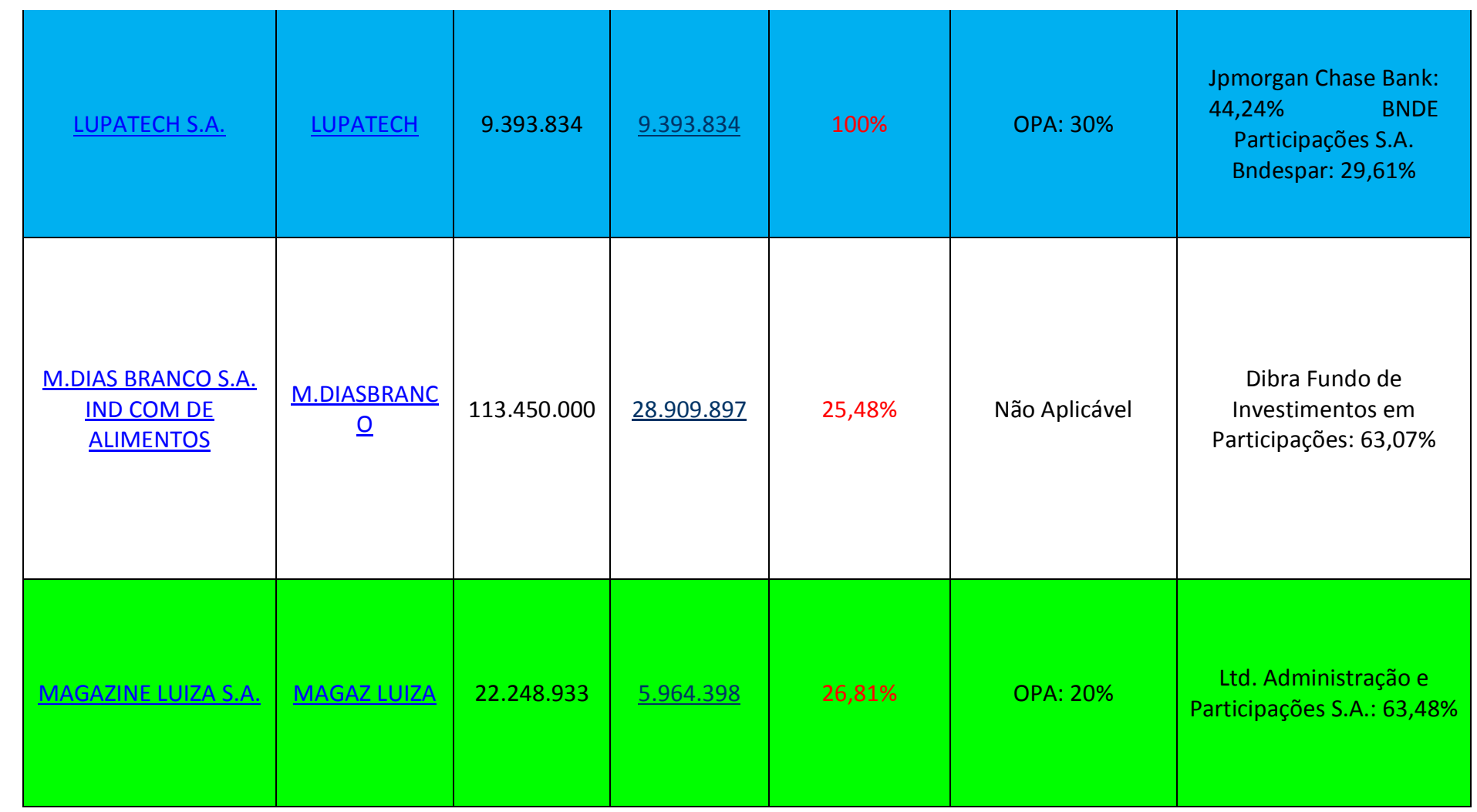




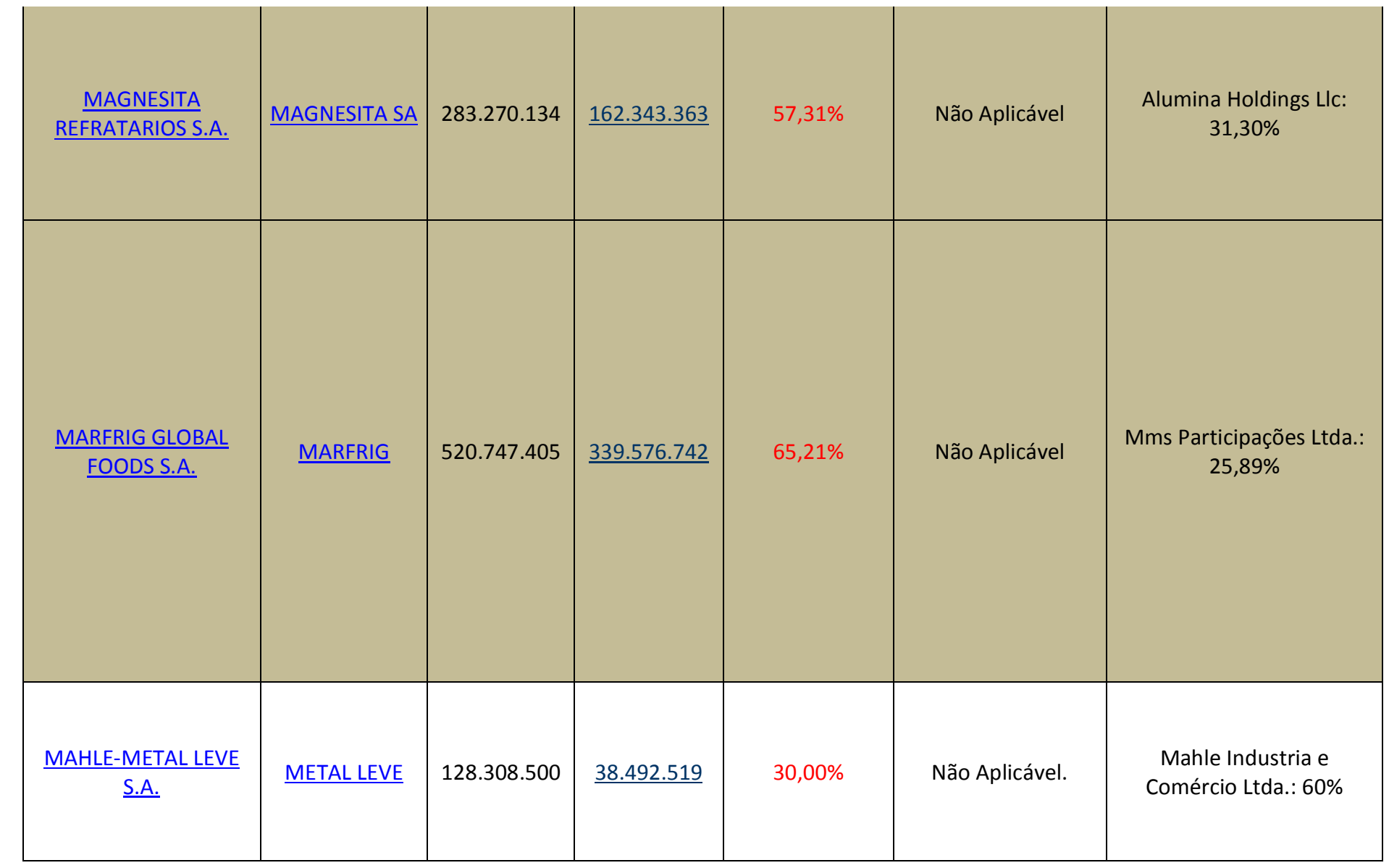




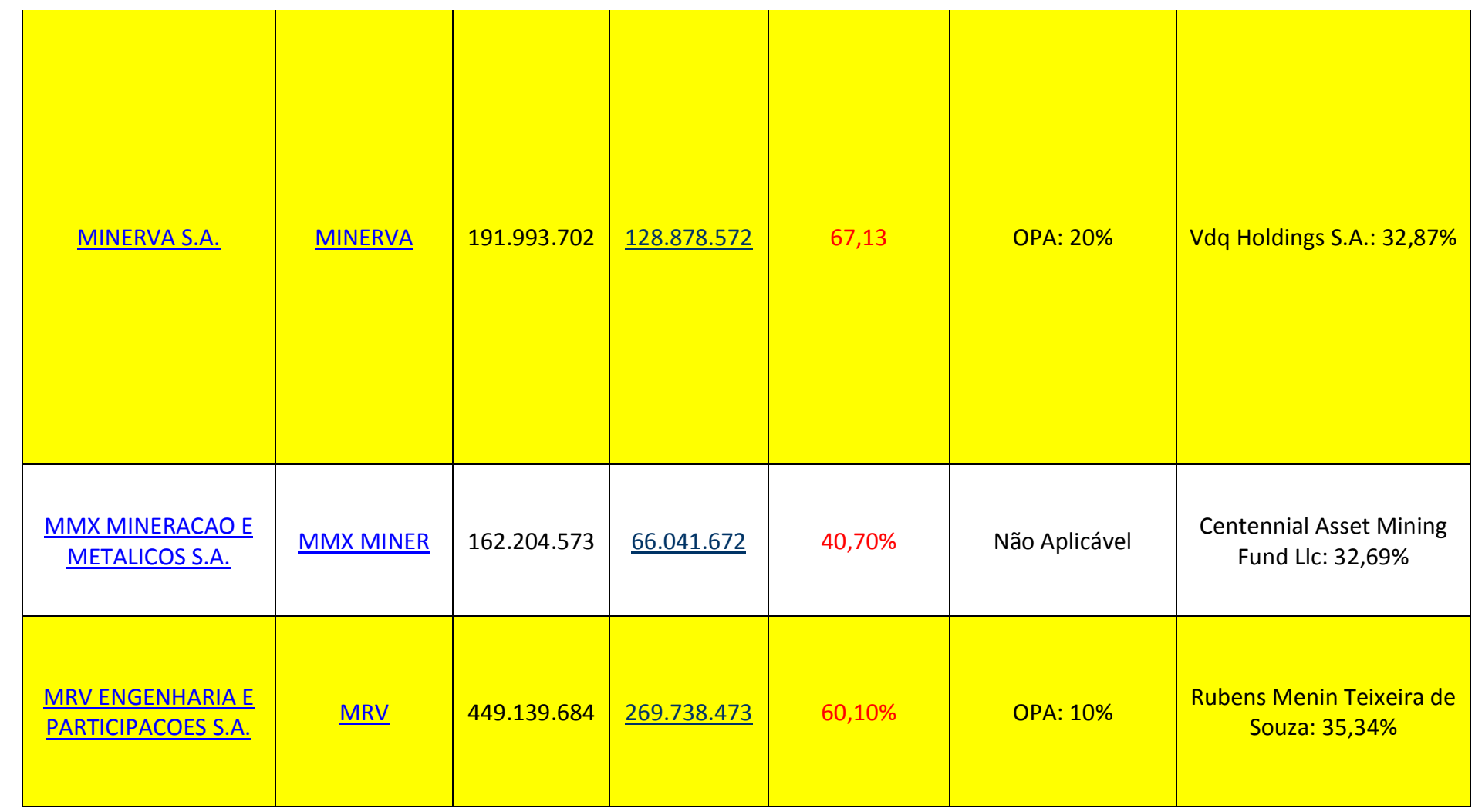




\begin{tabular}{|c|c|c|c|c|c|c|}
\hline MULTIPLUS S.A. & MULTIPLUS & 162.246 .573 & $\underline{44.140 .205}$ & $27,21 \%$ & Não aplicável & TAM: $72,74 \%$ \\
\hline$\frac{\text { NATURA COSMETICOS }}{\underline{\text { S.A. }}}$ & NATURA & 431.239 .264 & $\underline{171.984 .796}$ & $39,88 \%$ & OPA: $25 \%$ & \begin{tabular}{cc}
\multicolumn{2}{l}{ Lisis Participações S.A.: } \\
$22,25 \%$ & Utopia \\
Participações S.A.: & $21,23 \%$
\end{tabular} \\
\hline ODONTOPREV S.A. & ODONTOPREV & 531.294 .792 & $\underline{269.986 .765}$ & $50,82 \%$ & OPA: 15\% & $\begin{array}{c}\text { Bradesco Saúde S.A.: } \\
50,01 \%\end{array}$ \\
\hline $\begin{array}{c}\text { ÓLEO E GÁS } \\
\text { PARTICIPAÇÕES S.A. }\end{array}$ & OGX PETROLEO & $\begin{array}{c}3.236 .016 .79 \\
0\end{array}$ & $\frac{1.610 .000 .76}{\underline{6}}$ & $49,75 \%$ & Não Aplicável & $\begin{array}{l}\text { Centennial Asset Mining } \\
\text { Fund Llc: } 46,59 \% \\
\text { Centennial Asset Brazilian } \\
\text { Equitu Fund Llc: } 3,58 \%\end{array}$ \\
\hline
\end{tabular}




\begin{tabular}{|c|c|c|c|c|c|c|}
\hline OSX BRASIL S.A. & OSX BRASIL & 312.563 .568 & 106.220 .326 & $33,98 \%$ & Não Aplicável & $\begin{array}{l}\text { Centennial Asset Mining } \\
\text { Fund LIc: } 54,17 \%\end{array}$ \\
\hline $\begin{array}{l}\frac{\text { OURO FINO SAUDE }}{\text { ANIMAL }} \\
\text { PARTICIPACOES S.A. }\end{array}$ & OUROFINO S/A & 53.942 .307 & $\underline{22.670 .347}$ & $42,02 \%$ & Não Aplicável & $\begin{array}{l}\text { Jardel Massari: } 27,50 \% \\
\text { Norival Bonamichi: } 27,50 \%\end{array}$ \\
\hline PARANAPANEMA S.A. & $\frac{\text { PARANAPANE }}{\text { MA }}$ & 319.176 .942 & 318.776 .136 & $99,87 \%$ & Não Aplicável & $\begin{array}{c}\text { Caixa de Previdencia dos } \\
\text { Funcionário do BB -- Previ: } \\
23,96 \%\end{array}$ \\
\hline
\end{tabular}




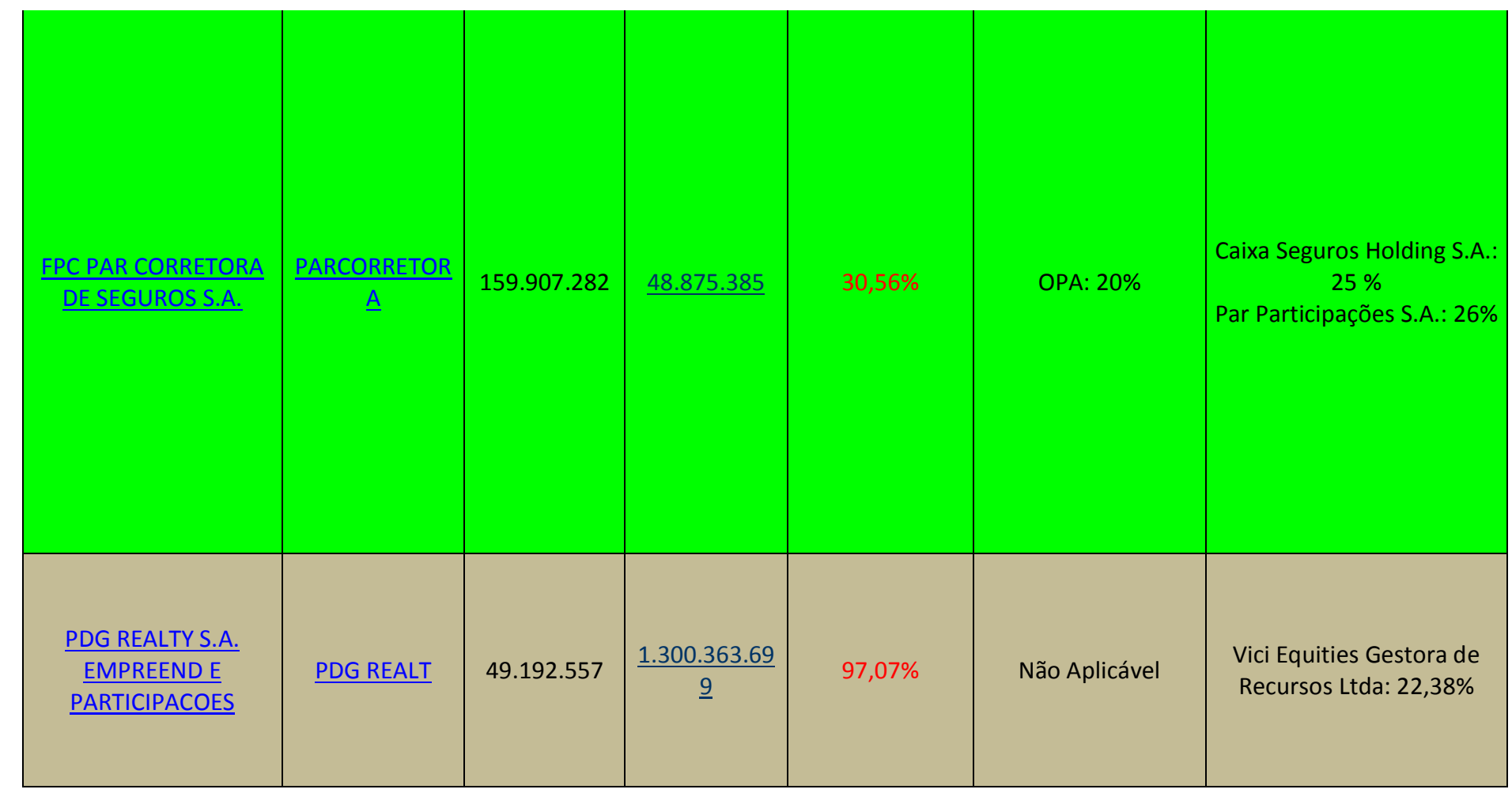




\begin{tabular}{|c|c|c|c|c|c|c|}
\hline PETRO RIO S.A. & PETRORIO & 29.748 .449 & $\underline{29.726 .533}$ & $99,93 \%$ & Não Aplicável. & $\begin{array}{l}\text { Bridge Administradora de } \\
\text { Recursos: } 19,90 \%\end{array}$ \\
\hline PORTO SEGURO S.A. & $\frac{\text { PORTO }}{\underline{\text { SEGURO }}}$ & 323.293 .030 & $\underline{94.239 .291}$ & $29,18 \%$ & OPA: $10 \%$ & $\begin{array}{c}\text { Porto Seguro Itau } \\
\text { Unibanco Participações: } \\
70,82 \%\end{array}$ \\
\hline PORTOBELLO S.A. & PORTOBELLO & 158.488 .517 & $\underline{72.769 .371}$ & $45,91 \%$ & OPA: $30 \%$ & $\begin{array}{c}\text { Cesar Gomes Junio: } \\
16,36 \%\end{array}$ \\
\hline $\begin{array}{l}\frac{\text { POSITIVO }}{\text { INFORMATICA S.A. }} \\
\text {. }\end{array}$ & POSITIVO INF & 87.800 .000 & $\underline{23.136 .298}$ & 26,35 & OPA: $10 \%$ & $\begin{array}{l}\text { Helio Bruck Rotenberg: } \\
14,14 \% \text { Cixares } \\
\text { Libero Vargas: } 14,14 \%\end{array}$ \\
\hline
\end{tabular}




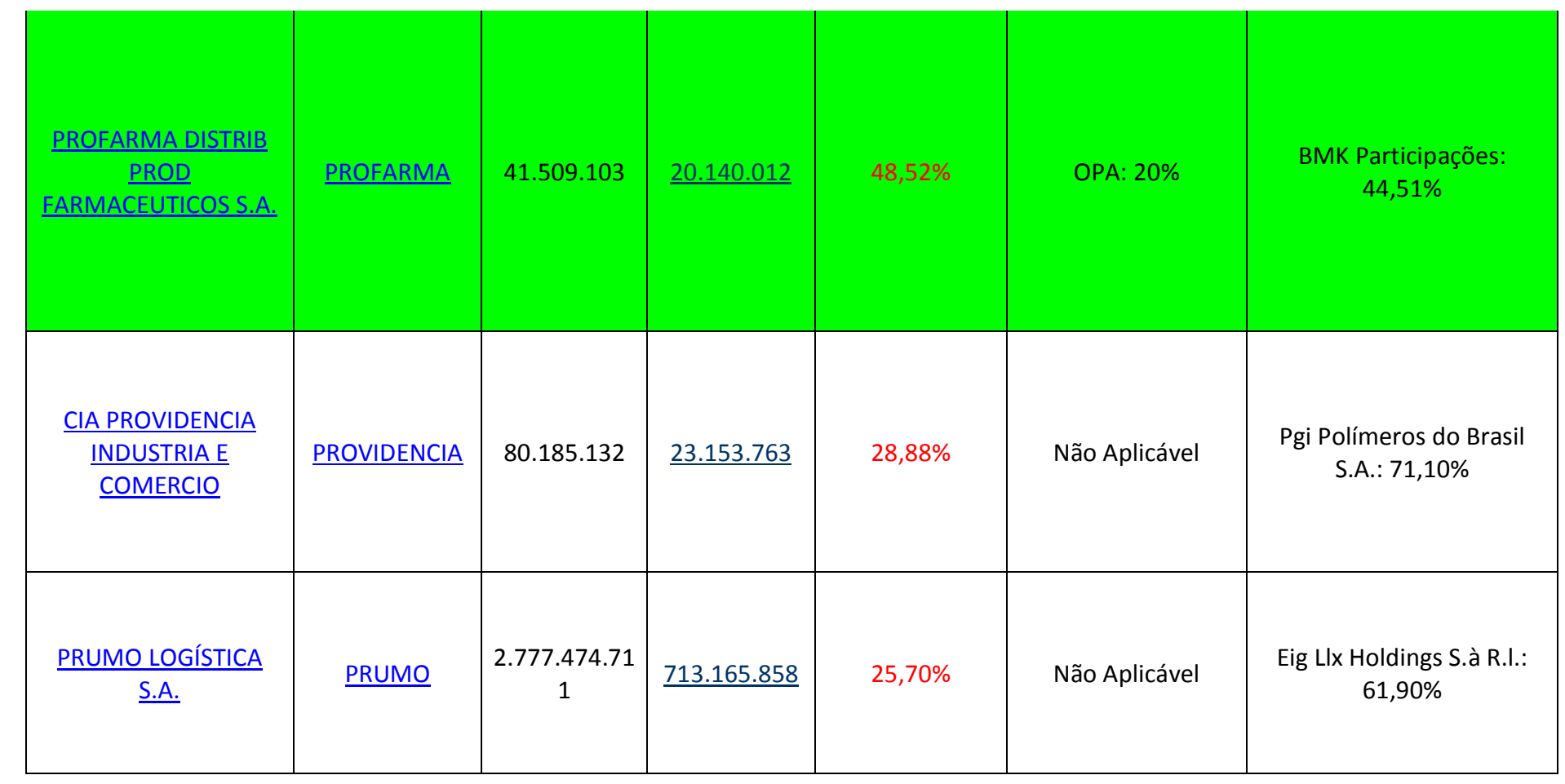




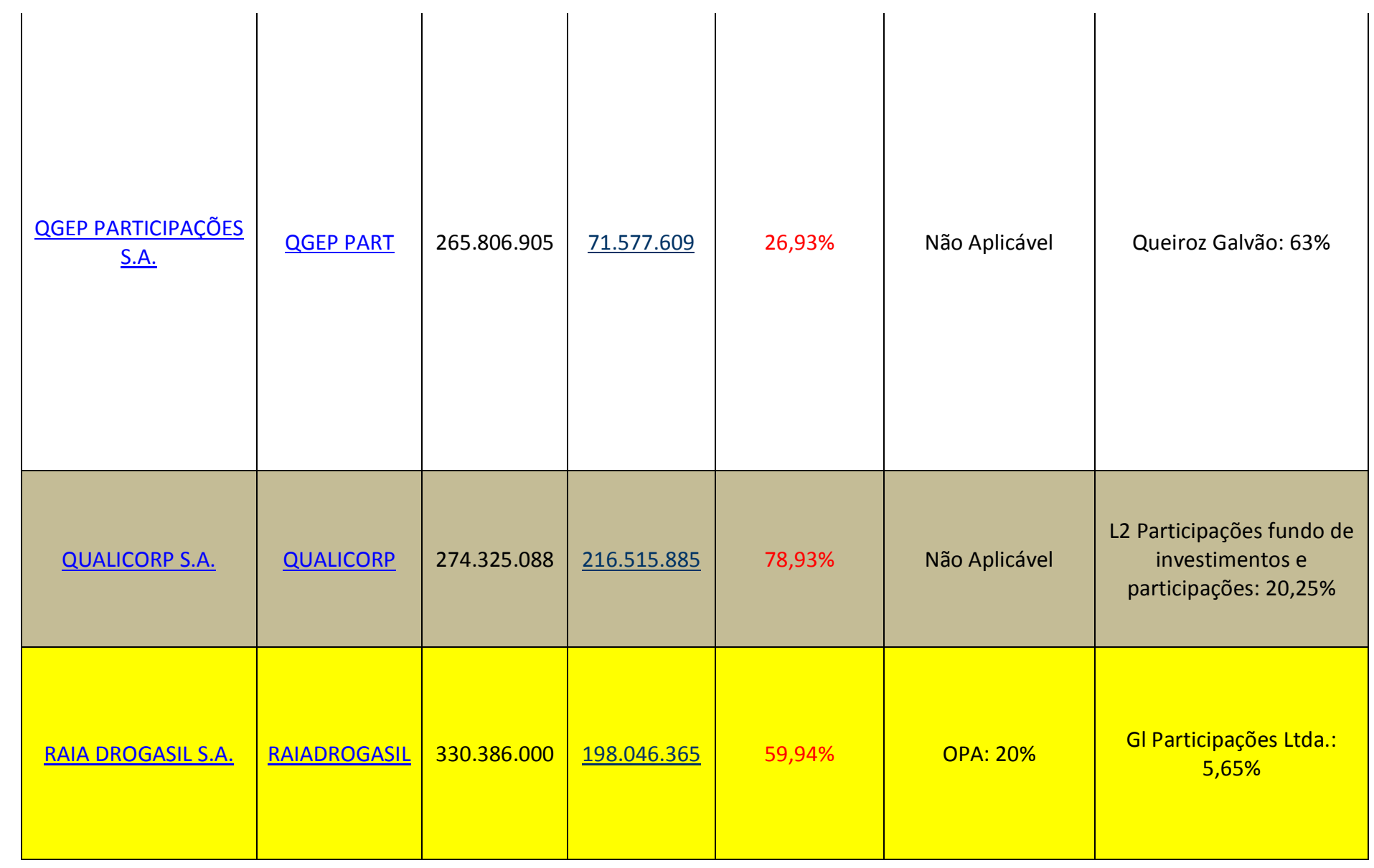




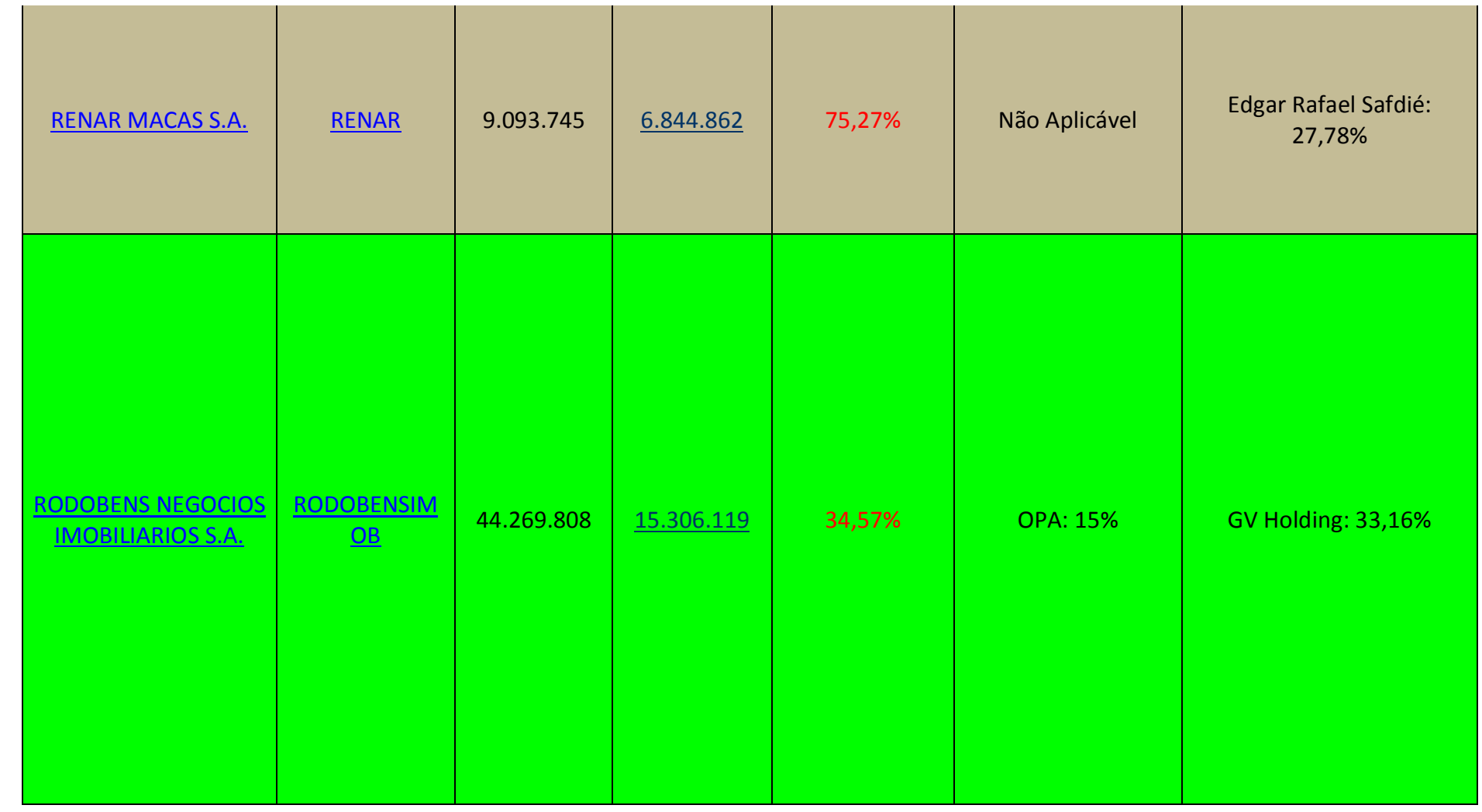




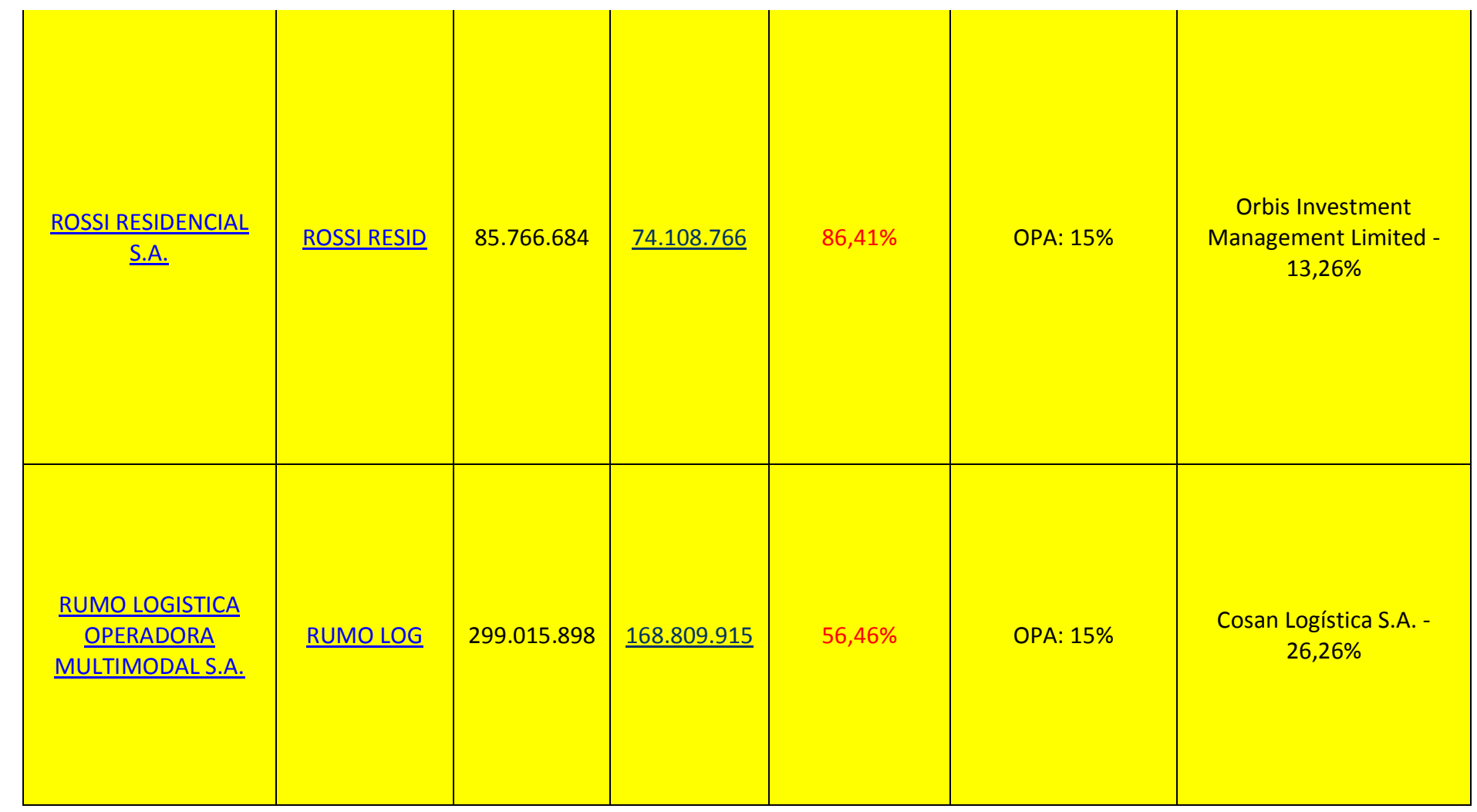




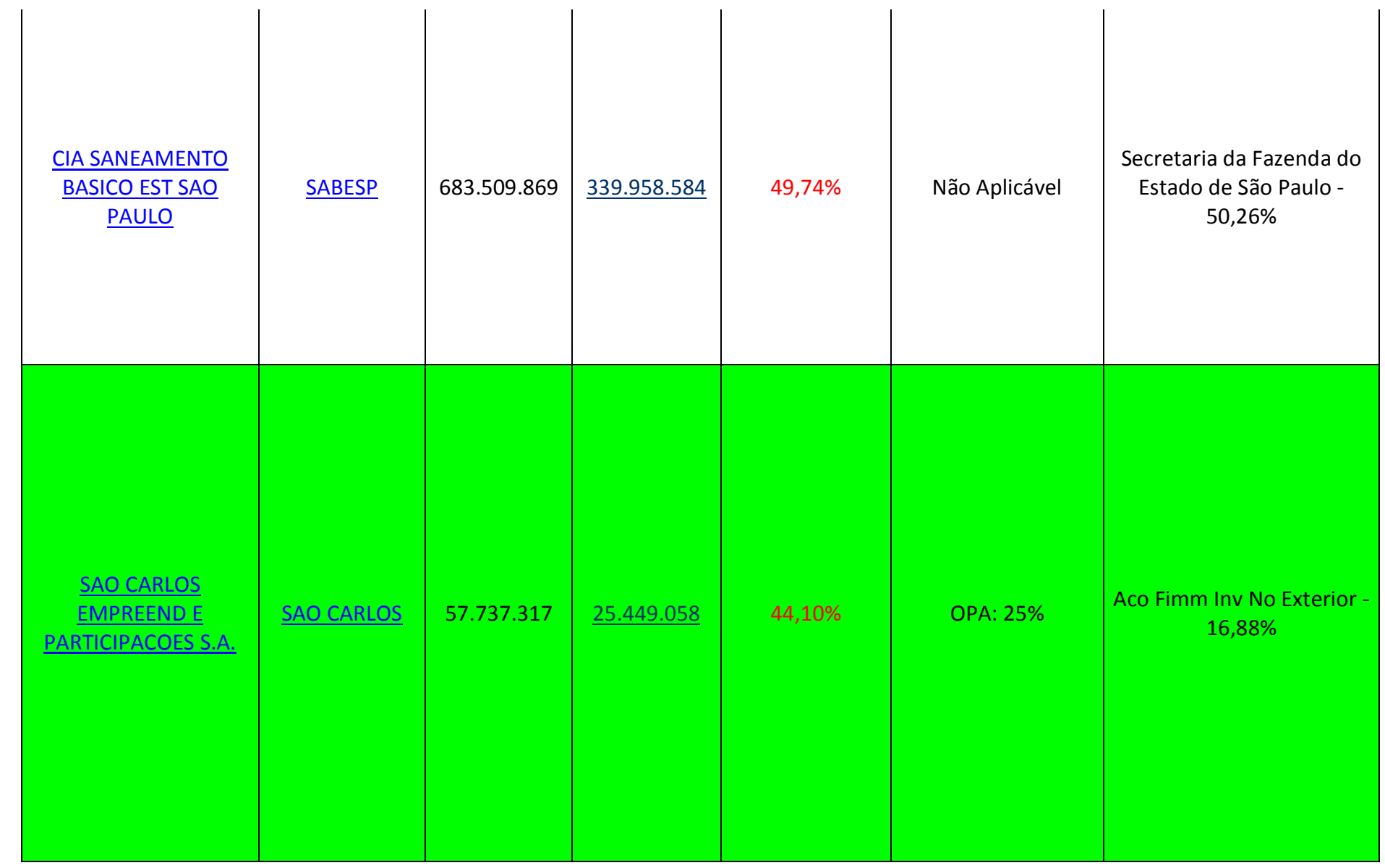




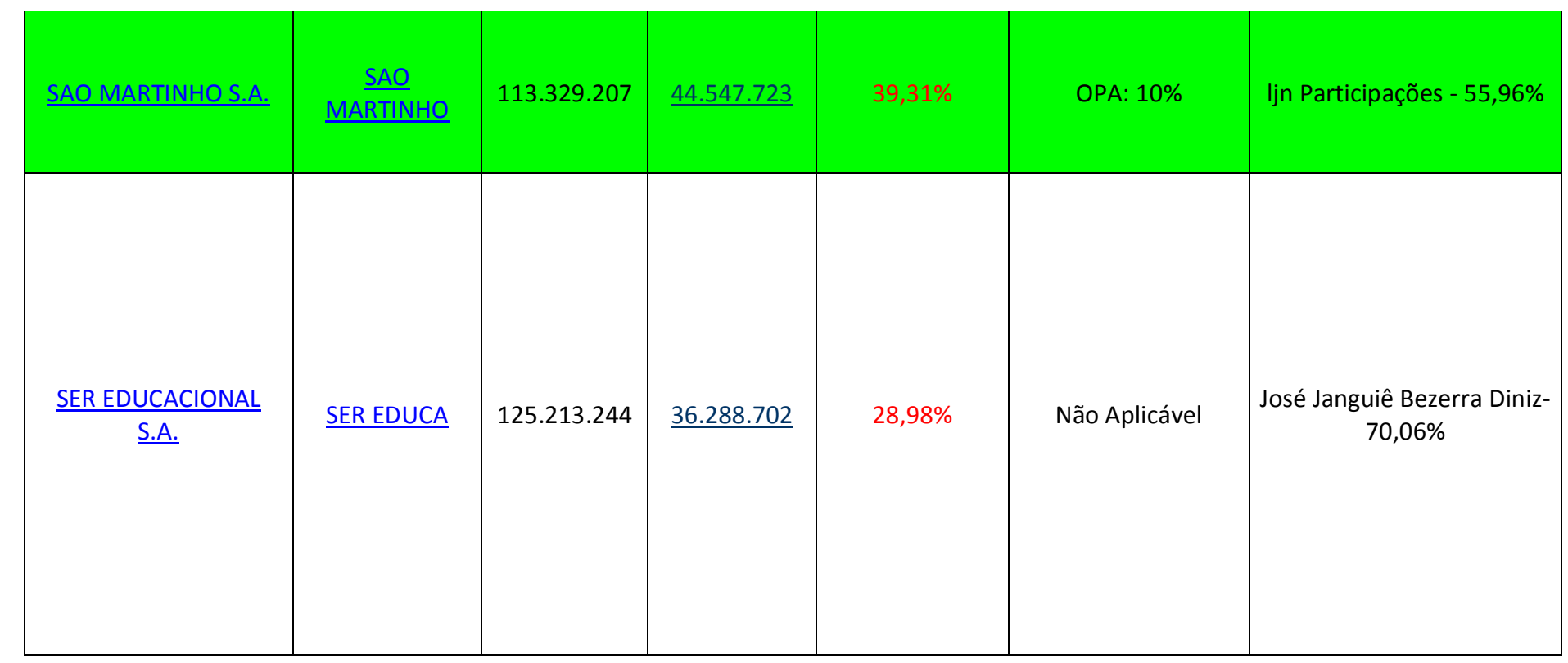




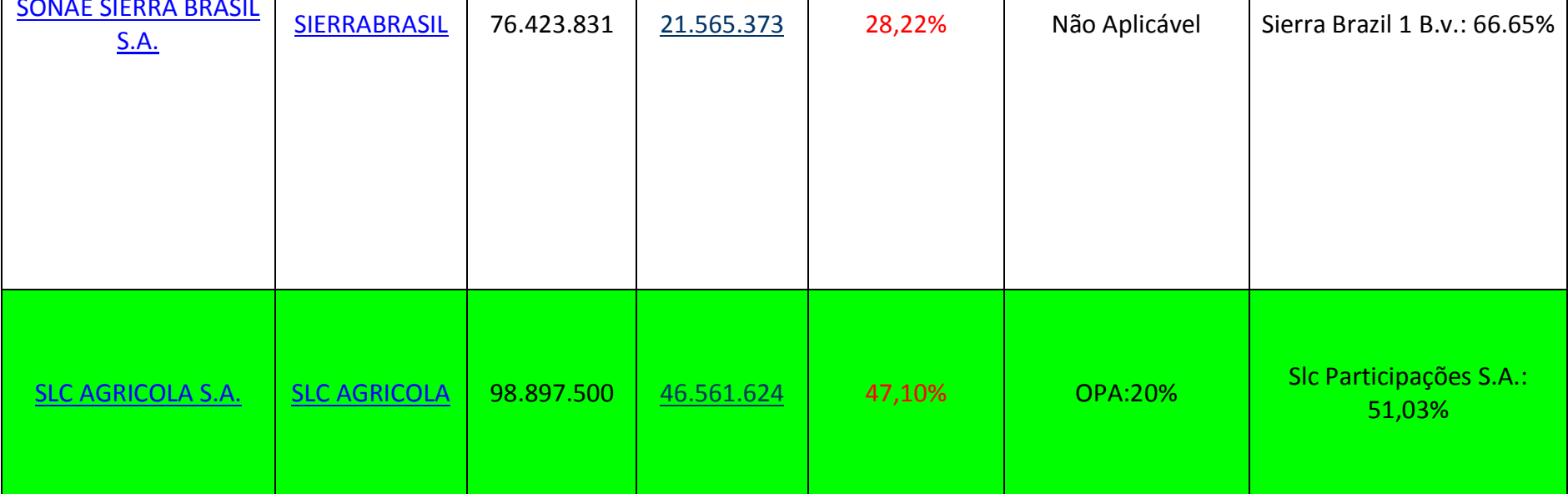




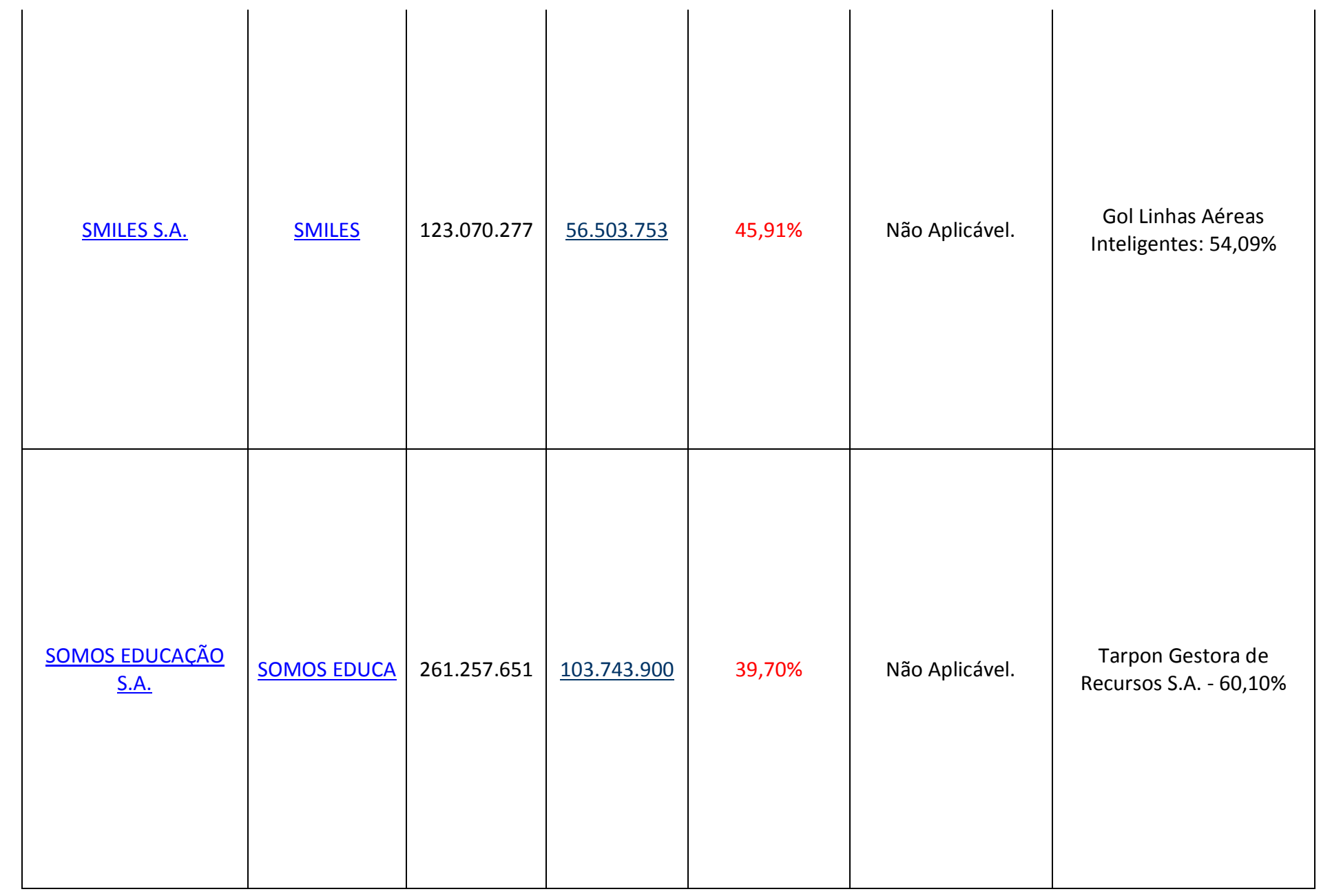




\begin{tabular}{|c|c|c|c|c|c|c|}
\hline $\begin{array}{c}\text { SPRINGS GLOBAL } \\
\text { PARTICIPACOES S.A. }\end{array}$ & SPRINGS & 200.000 .000 & $\underline{94.169 .173}$ & $47,08 \%$ & OPA: $25 \%$ & $\begin{array}{c}\text { Cia de tecidos Norte de } \\
\text { Minas - Coteminas: } 52 \text {, } \\
91 \%\end{array}$ \\
\hline$\frac{\text { TARPON }}{\text { INVESTIMENTOS S.A. }}$ & TARPON INV & 45.999 .897 & $\underline{16.926 .102}$ & $36,80 \%$ & Não Aplicável & $\begin{array}{l}\text { Mangue Participações } \\
\text { Itda. - } 60,49 \%\end{array}$ \\
\hline TECHNOS S.A. & TECHNOS & 78.506 .215 & 66.578 .654 & $84,81 \%$ & OPA: $33 \%$ & Dynamo - 29,24\% \\
\hline
\end{tabular}




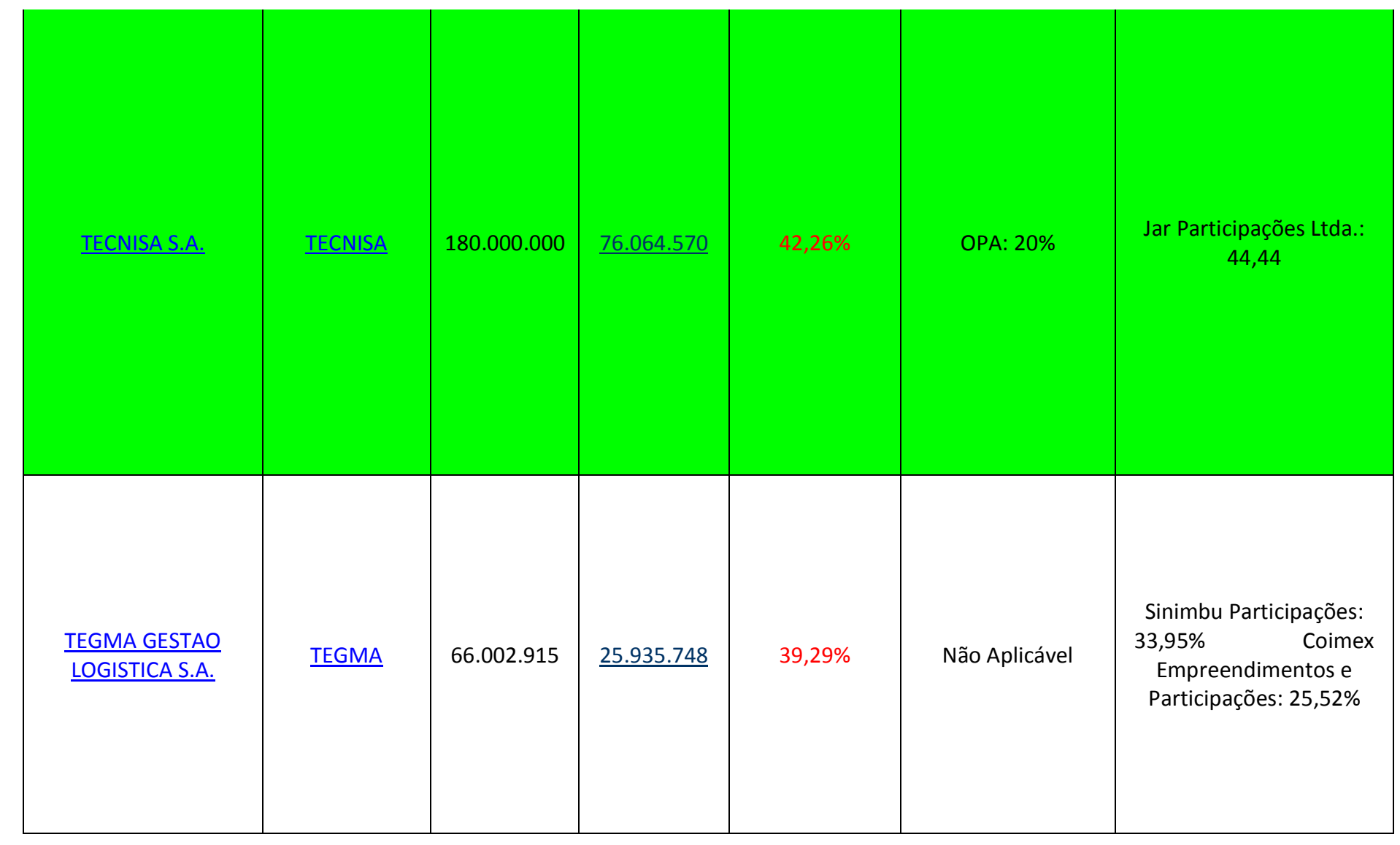




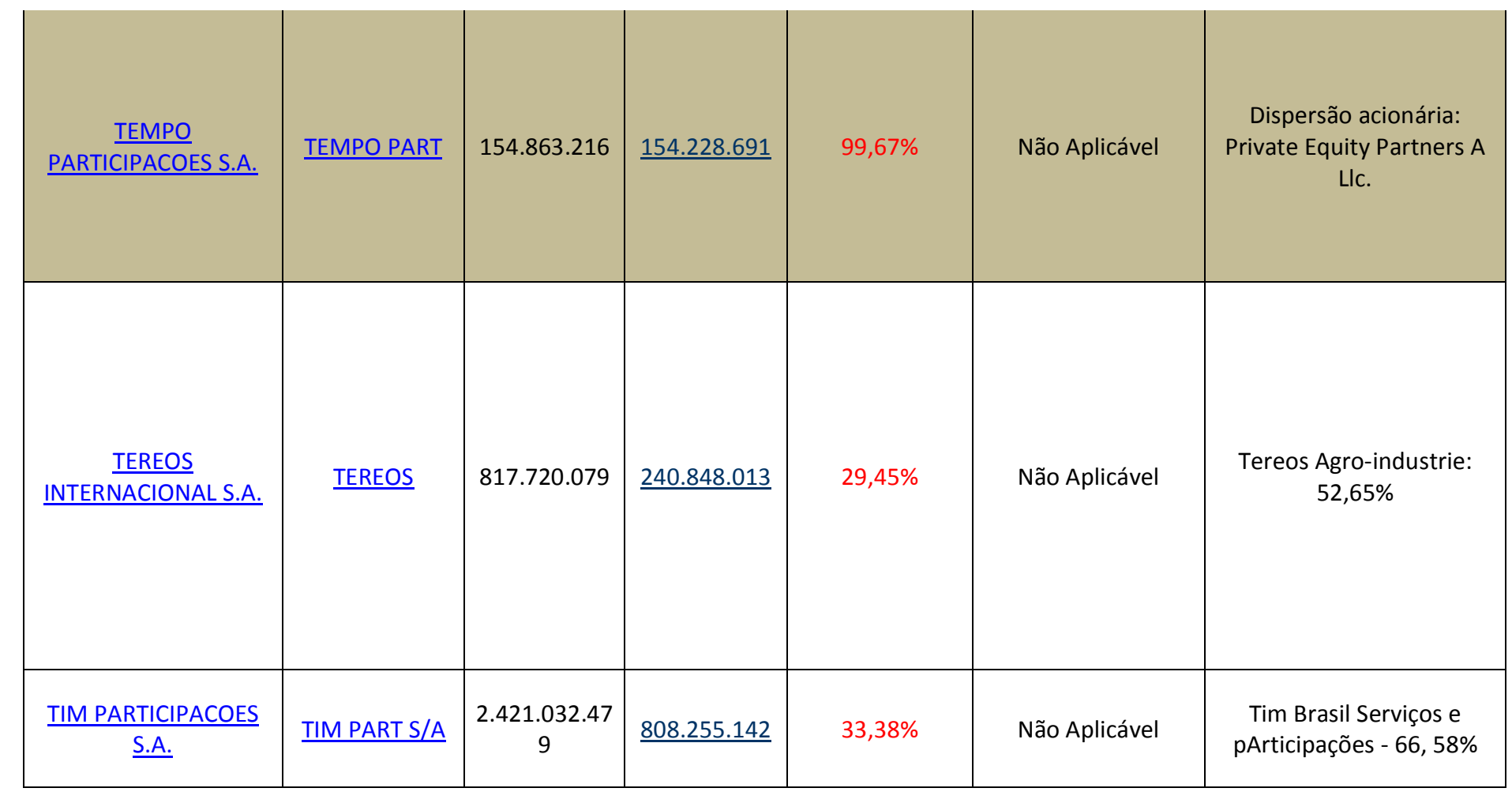




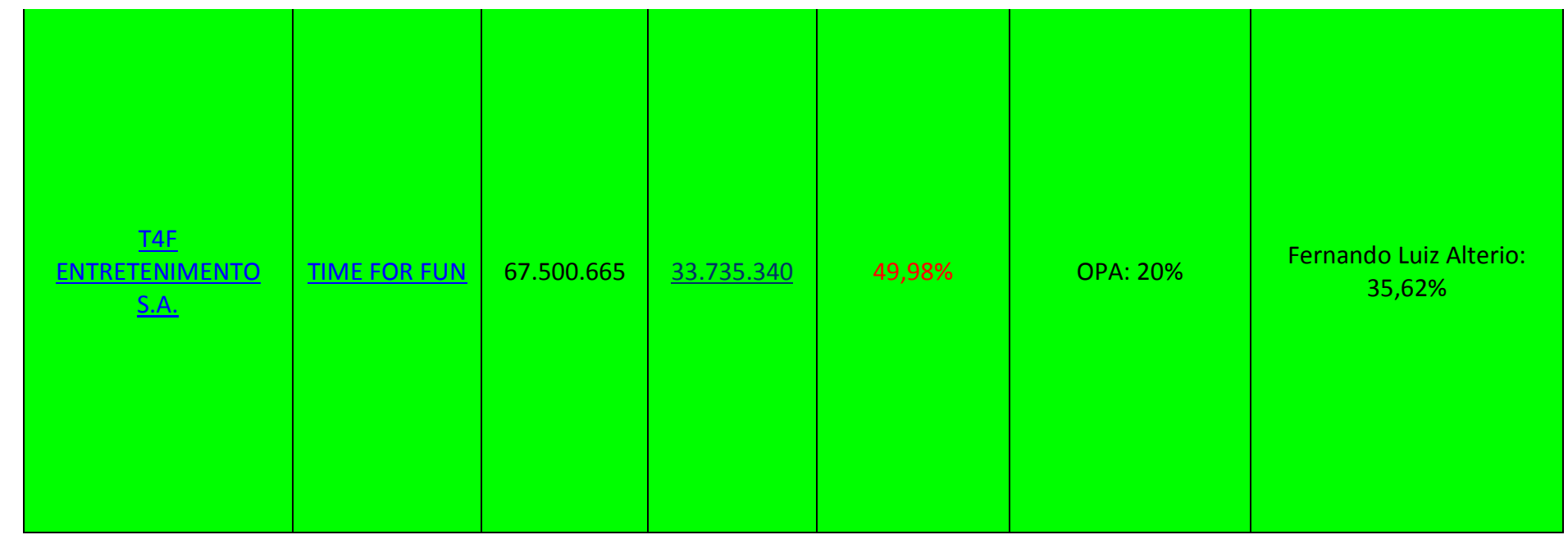




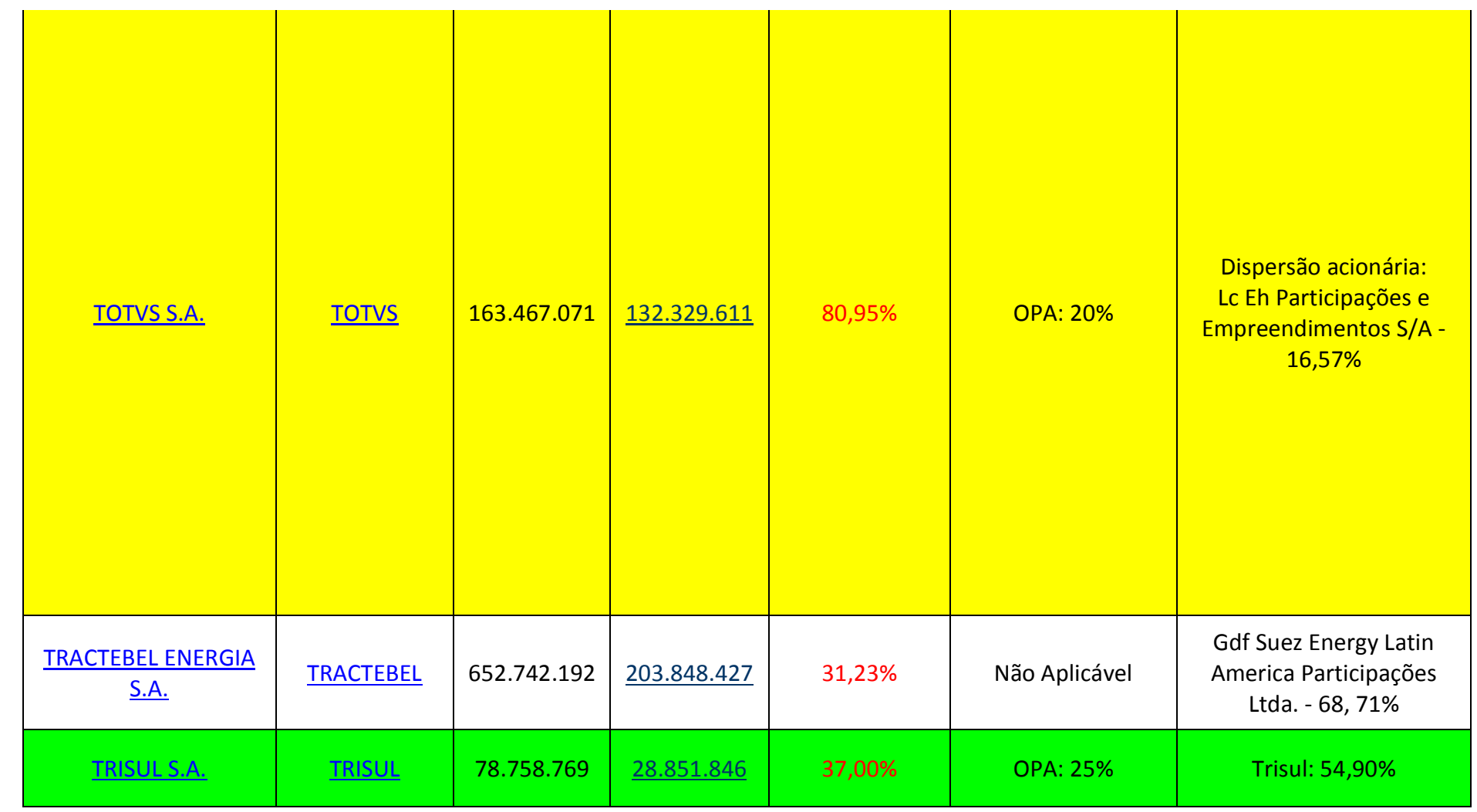




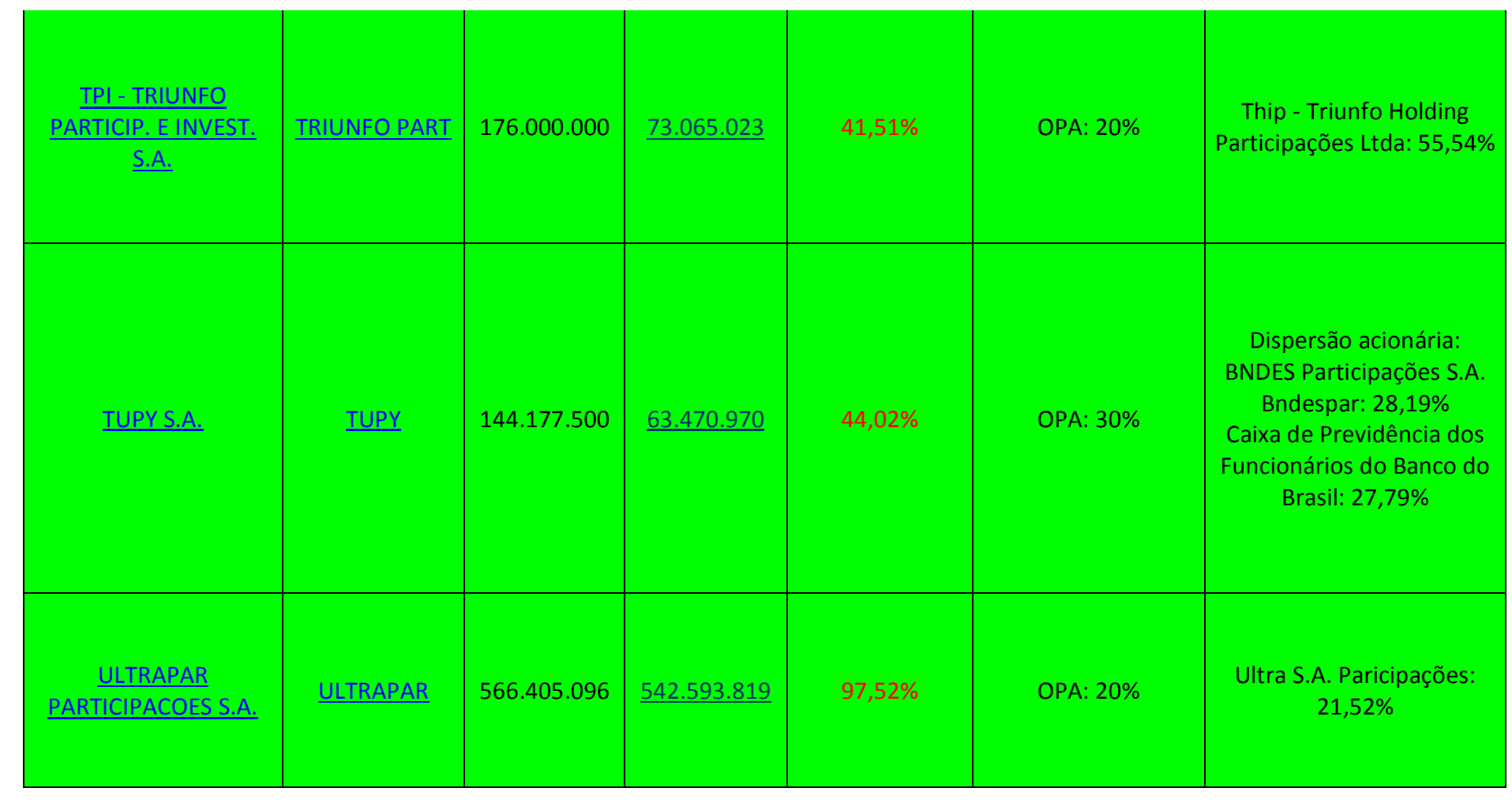




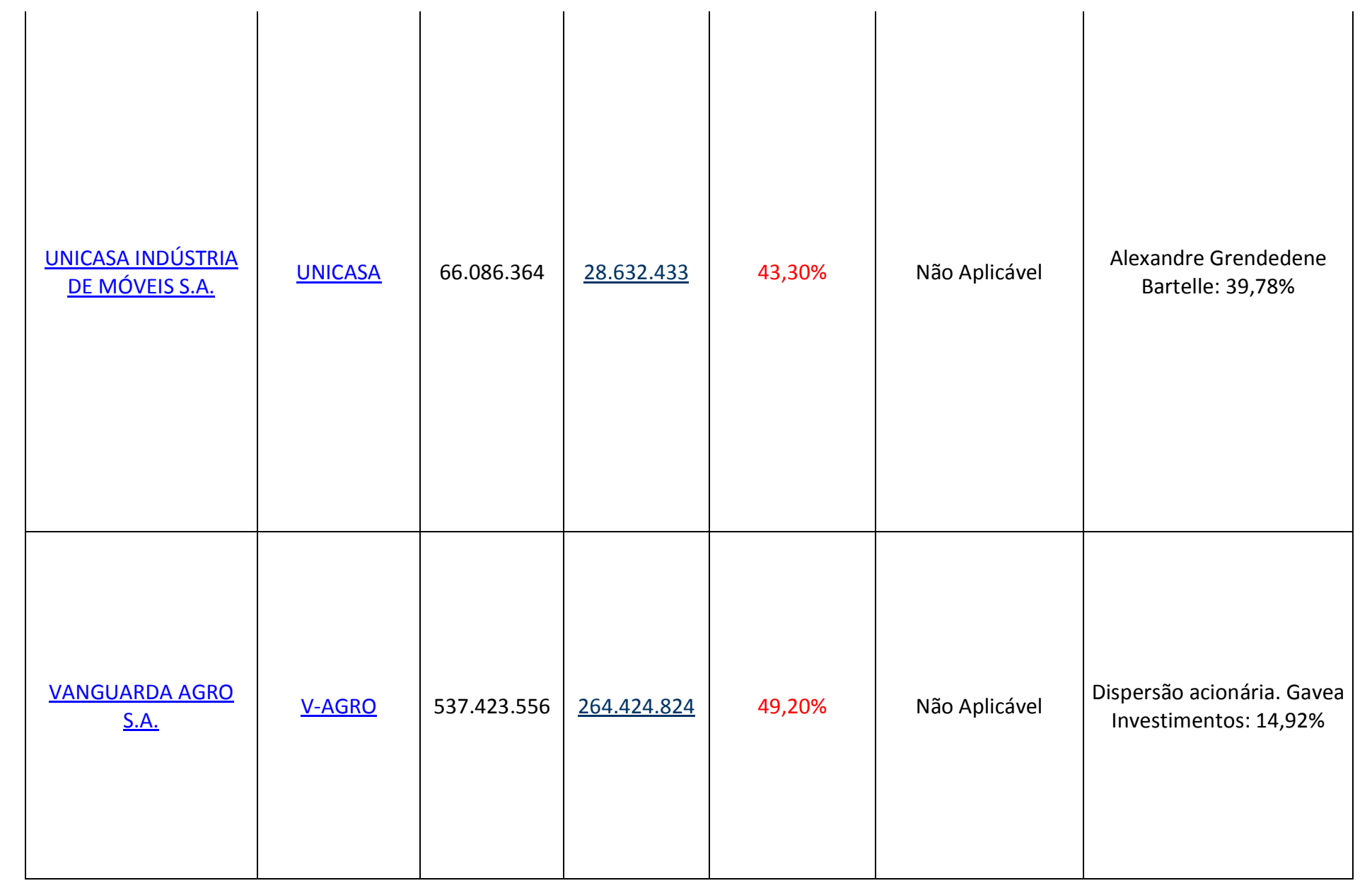




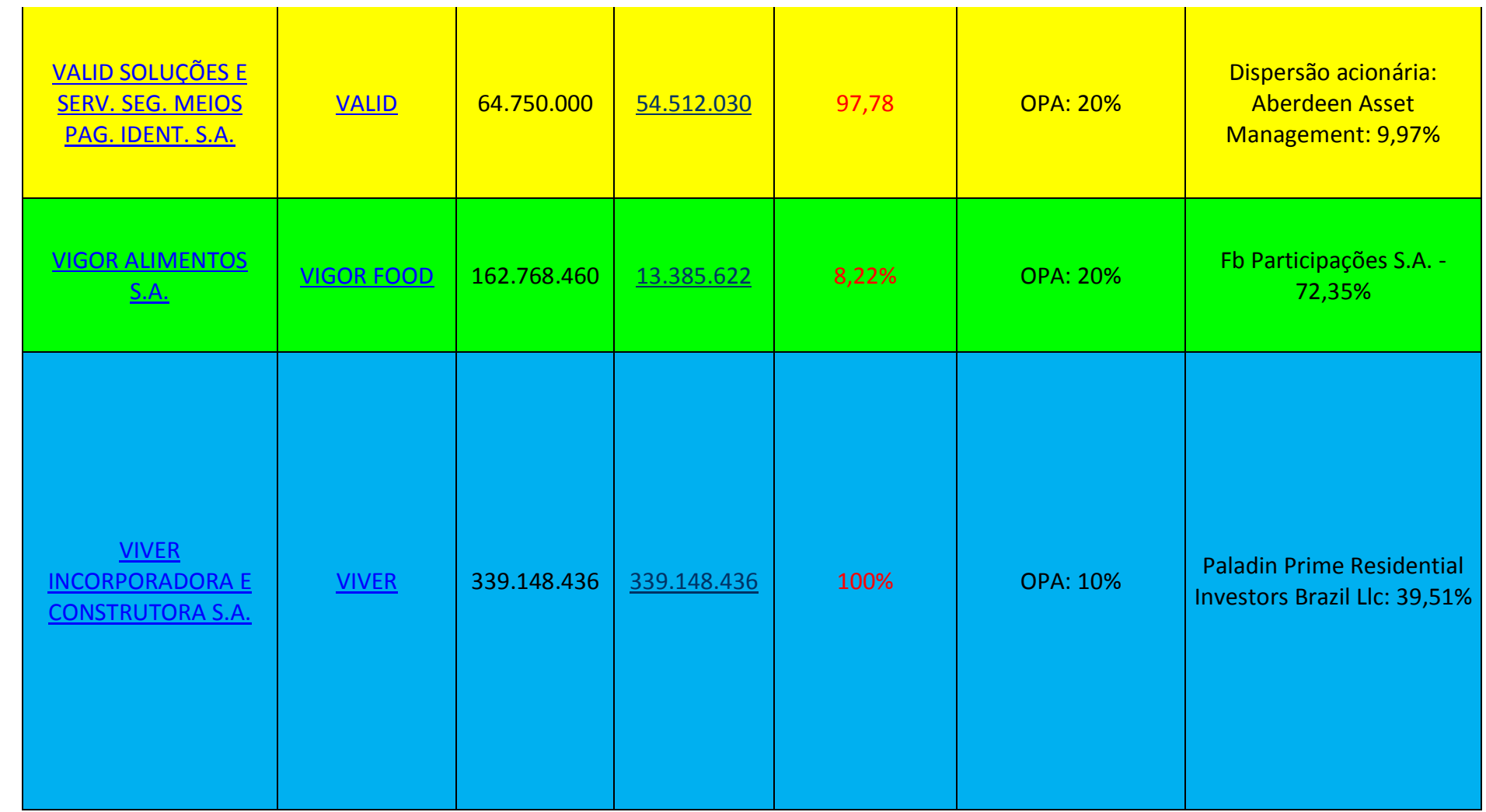




\begin{tabular}{|c|c|c|c|c|c|c|}
\hline WEG S.A. & WEG & $\begin{array}{c}1.614 .353 .07 \\
6\end{array}$ & $\underline{568.466 .875}$ & $35,21 \%$ & Não Aplicável & $\begin{array}{c}\text { Wpa Participações e } \\
\text { Serviços S.A. - 50.09\% }\end{array}$ \\
\hline . & & & & & $\begin{array}{l}\text { Amarelo: Empresas } \\
\text { com mais de 50\% } \\
\text { das ações em } \\
\text { circulação e } \\
\text { obrigatoriedade de } \\
\text { realização de OPA } \\
\text { Marrom: Empresas } \\
\text { com mais de 50\% } \\
\text { das ações em } \\
\text { circulação e não } \\
\text { obrigatoriedade de } \\
\text { realização de OPA } \\
\text { Azul: Empresas com } \\
100 \% \text { das ações em } \\
\text { circulação } \\
\text { Verde: Empresas } \\
\text { com menos de 50\% } \\
\text { das ações em } \\
\text { circulação e } \\
\text { obrigatoriedade de } \\
\text { realização de OPA }\end{array}$ & \\
\hline
\end{tabular}

